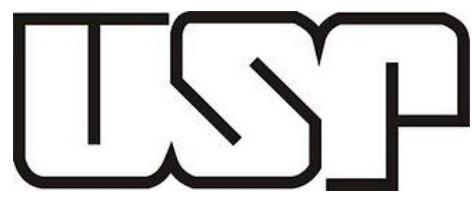

Universidade de São Paulo

Faculdade de Filosofia, Letras e Ciências Humanas

Departamento de Ciência Política

Carlos Joel Carvalho de Formiga-Xavier

\title{
A corrupção política e o Caixa 2 de campanha no Brasil
}

São Paulo

2010 


\section{A corrupção política e o Caixa 2 de campanha no Brasil}

Dissertação apresentada como requisito parcial à obtenção do grau de Mestre em Ciência Política pelo Programa de PósGraduação em Ciência Política da Universidade de São Paulo.

Orientador: Prof. Dr. José Álvaro Moisés 
AUTORIZO A REPRODUÇÃO E DIVULGAÇÃO TOTAL OU PARCIAL DESTE TRABALHO, POR QUALQUER MEIO CONVENCIONAL OU ELETRÔNICO, PARA FINS DE ESTUDO E PESQUISA, DESDE QUE CITADA A FONTE.

Catalogação na Publicação

Serviço de Biblioteca e Documentação

Faculdade de Filosofia, Letras e Ciências Humanas da Universidade de São Paulo

Formiga - Xavier, Carlos Joel Carvalho de A corrupção política e o caixa 2 de campanha no Brasil / Carlos Joel Carvalho de Formiga - Xavier ; orientador José Álvaro Moisés. - São Paulo, 2011.

$$
127 \mathrm{f} \text {. }
$$

Dissertação (Mestrado) - Faculdade de Filosofia, Letras e Ciências Humanas da Universidade de São Paulo. Departamento de Ciência Política. Área de concentração: Ciência Política.

1. Corrupção - aspectos políticos - Brasil. 2. Democracia - qualidade - Brasil. 3. Financiamento de campanha eleitoral - Brasil. 4. Administração pública Brasil. 5. Prestação de contas. I. Título. II. Moisés, José Álvaro. 


\section{FOLHA DE APROVAÇÃO}

\section{Carlos Joel Carvalho de Formiga-Xavier}

\section{A corrupção política e o Caixa 2 de campanha no Brasil}

Dissertação apresentada ao Departamento de Ciência Política da Universidade de São Paulo para obtenção do título de mestre.

Área de concentração: política brasileira

Aprovado em

Banca examinadora

Prof. Dr.

Instituição Assinatura

Prof. Dr.

Instituição Assinatura 
Aos brasileiros

um grão de esperança 


\section{Agradecimentos}

À minha mãe, pelos estímulos, pelo exemplo e padrão de excelência desde minha mais tenra idade.

À Bia, minha esposa e companheira, pelas forças, pelas duras, pela Pipoca, os cafezinhos e o aconchego; enfim: pelo amor sem o qual nenhum esforço faria sentido.

A San Romanelli Assumpção, amiga e colega de quem me orgulho, por toda a ajuda e dedicação, sempre aberta e disponível ao diálogo, com sua capacidade luminosa de transformar dúvida em conhecimento, lacunas em ideias estruturadas.

A José Álvaro Moisés, meu orientador, pela sabedoria e paciência no equilíbrio exato entre motivação e cobrança, entre orientação e liberdade criativa, e pelo respeito e apoio valioso ao trabalho intelectual.

A Rogério Oliveira, meu chefe e amigo, por ter acreditado em mim e investido no meu desenvolvimento, pelo interesse em política e pela disposição em discuti-la. 
FORMIGA-XAVIER, Carlos Joel Carvalho de. A corrupção política e o Caixa 2 de campanha no Brasil. 2010. Dissertação (mestrado). Departamento de Ciência Política da Universidade de São Paulo, São Paulo, 2010.

\section{Resumo}

Esta dissertação estuda a corrupção política e o Caixa 2 de campanhas eleitorais no Brasil, avaliando o seu impacto na qualidade da democracia, em especial na responsividade dos governos às preferências da maioria dos cidadãos. Com base em observações descritivas a partir de depoimentos, notícias de jornal e dados de pesquisa, busca-se investigar como os fenômenos estudados afetam o funcionamento do accountability vertical e distorcem a competição eleitoral. 
FORMIGA-XAVIER, Carlos Joel Carvalho de. A corrupção política e o Caixa 2 de campanha no Brasil. 2010. Dissertação (mestrado). Departamento de Ciência Política da Universidade de São Paulo, São Paulo, 2010.

\begin{abstract}
This dissertation studies political corruption and slush funds in electoral campaigns in Brazil, assessing their impact in the quality of democracy, specially on the responsiveness of governments to the preferences of the majority of the citizens. Based on descriptive observations from public statements, newspaper articles and existing research data, an attempt is made to investigate how these phenomena affect the proper functioning of vertical accountability and distort electoral competition.
\end{abstract}




\section{SUMÁRIO}

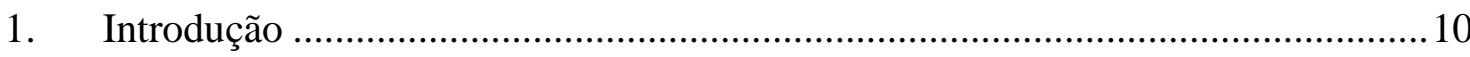

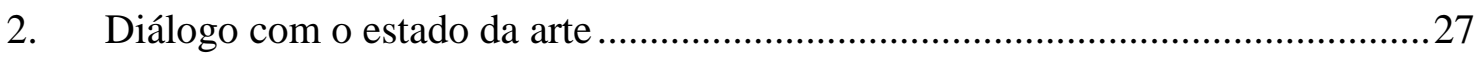

2.1. Corrupção política: definição e delimitações …………………………………........27

2.2. Fatores que influenciam os níveis de corrupção ..................................................31

2.3. Efeitos da corrupção sobre a qualidade da democracia .........................................36

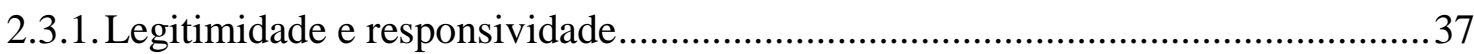

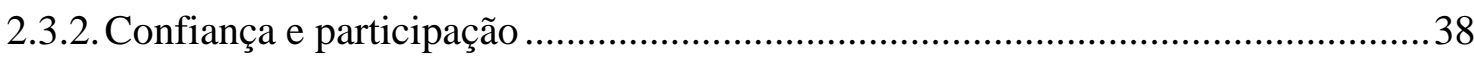

2.3.3. Igualdade política e desigualdades sociais ............................................................4

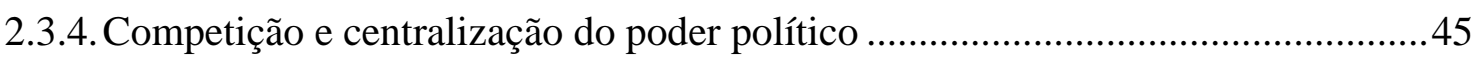

3. Os custos das campanhas eleitorais e o comportamento do eleitor na construção dos incentivos à corrupção política no Brasil....................................................................4

3.1. Níveis de corrupção política no Brasil ..................................................................49

3.2. A (in)eficácia do accountability vertical como instrumento de punição dos

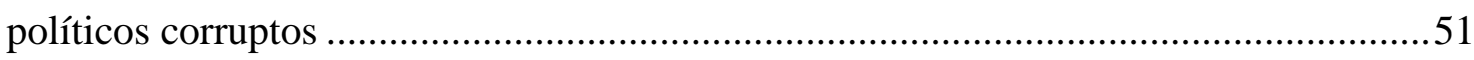

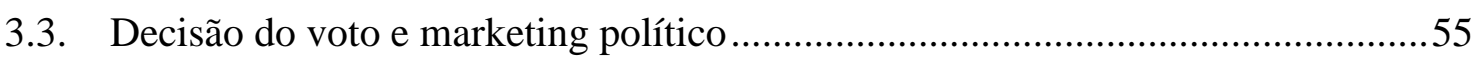

3.4. O alto custo das campanhas e peso do dinheiro nas eleições ...................................60

3.5. Competição entre elites políticas e entre seus financiadores...................................65

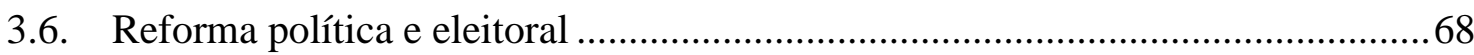

4. O Caixa 2 no financiamento de campanhas eleitorais ............................................72

4.1. O financiamento público de campanha e o horário gratuito para propaganda

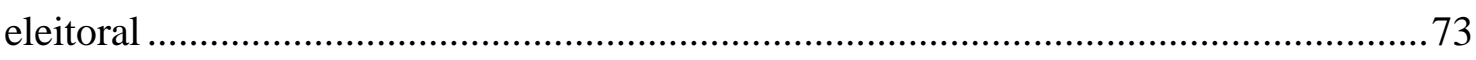

4.2. O financiamento privado e o Caixa 2 de campanha...............................................76

4.3. As eleições para governador no estado do Amapá em 2010 ..................................79

4.4. Limites legais e doadores "laranjas" - a investigação conjunta do TSE e da

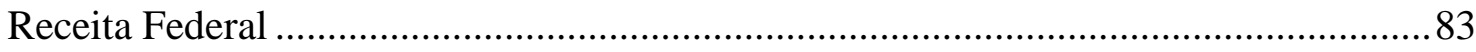

4.5. Doações ocultas - Anonimato ou Caixa 2 "esquentado"? .......................................87

4.6. Por que uma empresa doa em Caixa 2? ...........................................................92

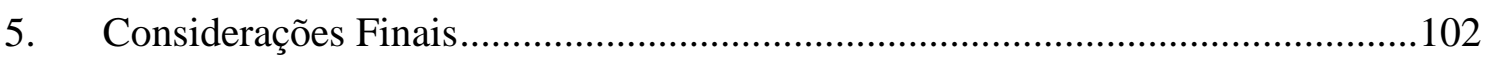

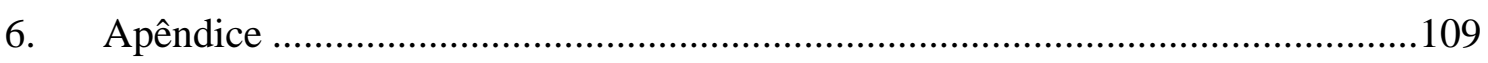

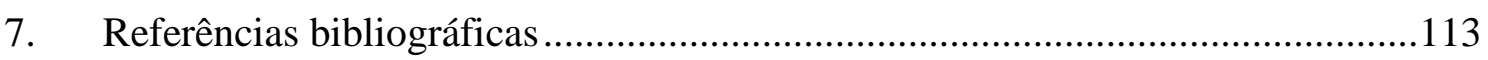




\section{Capítulo 1}

\section{Introdução}

Esse estudo parte de três premissas. 1) É desejável que o governo seja responsivo, considerando que isso se dá quando formula e implementa políticas conforme a preferência da maioria dos cidadãos; 2) A responsividade varia com as escolhas e ações dos atores detentores do poder político outorgado pelo voto; e 3) As instituições democráticas, apoiadas por uma cultura de massa compatível com os valores democráticos, devem funcionar de modo a criar a possibilidade e aumentar a probabilidade de que a responsividade seja efetiva (a partir de Dahl, 1977). É sabido, entretanto, que a existência de práticas de corrupção afeta a responsividade, central à qualidade da democracia ${ }^{1}$. Por isso, pretende-se examinar nessa dissertação como o accountability vertical, mecanismo central ao funcionamento do regime democrático através do qual os eleitores podem premiar ou punir os atores políticos que agem de acordo ou em desacordo com suas preferências, opera sobre a corrupção política e é por ela influenciado, com foco particular sobre o fenômeno do chamado Caixa 2 de campanha $^{2}$.

O termo corrupção cobre uma vasta gama de significados. Fernando Filgueiras observa que "não há, na tradição do pensamento político ocidental, consenso a respeito do que vem a ser a corrupção" (2008-a, p. 353). Antes da modernidade, a palavra corrupção era usada principalmente no sentido moral. Tratava-se mais comumente da corrupção de valores, perversão ou depravação. Ainda hoje, o sentido reflexivo da expressão tem uma conotação semelhante: corromper-se é abrir mão de seus valores e crenças em resposta a algum estímulo material ou imaterial, seja ele positivo ou negativo. O conceito de corrupção adotado neste estudo não incorpora essa moralidade por vezes atribuída à expressão. Conforme aponta Filgueiras, "quanto ao conceito de corrupção, o

\footnotetext{
${ }^{1} \mathrm{O}$ conceito de qualidade da democracia é apresentada mais à frente nesse capítulo.

${ }^{2}$ A definição de Caixa 2 será apresentada adiante neste capítulo e discutida em detalhes no capítulo 4 desta dissertação.
} 
domínio da ciência moderna proporcionou uma virada em seu sentido linguístico, ao desvincular o problema da corrupção do problema moral das virtudes" (2008-b, p. 67). Renato Janine Ribeiro parece concordar, ao afirmar que "a corrupção antiga era dos costumes. A moderna é a da apropriação privada de fundos públicos, é apenas o furto da coisa pública, reduzida ao erário" (Ribeiro, 2006, p. 78).

É preciso, portanto, antes de prosseguir, que se adote uma definição que forneça os limites e contornos necessários para a discussão desse fenômeno. Rogério Arantes define o crime de corrupção política como

os casos em que o crime principal é a apropriação direta e malversação de fundos públicos ou fraude organizada e reiterada de atividades do Estado (autorização, concessão e/ou inspeção de interesses públicos, bens ou atividades econômicas), por agentes públicos (com ou sem envolvimento do setor privado) (Arantes, no prelo, p.25, tradução nossa).

Embora essa definição contenha um importante elemento de normatividade democrática ao definir a corrupção como crime, para fins desse estudo adotarei a definição técnica de Daniel Treisman, para quem "a corrupção política se caracteriza pelo uso indevido de bens públicos para fins privados" (Treisman, 2000, p. 2, tradução nossa). Sendo assim, ocorre corrupção política quando algo público é vendido em troca de um ganho privado. Aproxima-se, desse modo, da definição de corrupção como suborno, citada por alguns dicionários ${ }^{3}$, porém especificando-se o ator da venda como ator político. Em particular, focarei na corrupção praticada pelos atores políticos eleitos ou por aqueles agentes públicos diretamente por eles nomeados, agindo a seu mando ou em seu interesse. Pela definição adotada, fica claro que não se pretende abranger formas de corrupção que acontecem na esfera privada, e nem mesmo aquelas que, mesmo envolvendo bens públicos, são praticadas por burocratas ou agentes da administração pública que não se caracterizem como atores políticos ${ }^{4}$. Tal exclusão visa concentrar os esforços desse estudo na questão política, em seus atores principais e nos seus desdobramentos.

\footnotetext{
${ }^{3}$ Do dicionário Houaiss - suborno: "ato ou efeito de subornar; compra, corrupção", Consultado no site http://houaiss.uol.com.br/busca.jhtm?verbete=suborno\&stype=k, em 07 de janeiro de 2011.

${ }^{4}$ Desse modo, o ato de corrupção praticado por um policial que recebe propina de um motorista que comete uma infração de trânsito em troca de não multá-lo não caracteriza corrupção política nos moldes definidos para fins deste estudo.
} 
Para que o ator político ou o cidadão comum identifiquem e reconheçam a existência de corrupção, é necessário que tenham noção da diferença entre papéis públicos e interesses privados ${ }^{5}$ (Huntington, 1968). Essa diferenciação é uma conquista da modernidade. Em grande parte dos regimes ditatoriais do passado e mesmo em algumas ditaduras contemporâneas, os direitos e deveres do regente e dos agentes públicos não eram facilmente percebidos como dissociados entre públicos e privados, as esferas se confundiam, e tornavam difícil a tarefa de caracterizar a corrupção política. Sugere-se aqui, entretanto, que o Brasil é uma democracia razoavelmente consolidada, permitindo alguma clareza sobre essa distinção. Uma evidência disso é a recente discussão sobre nepotismo no Judiciário, amplamente condenado pela sociedade, a ponto de a sua proibição ter se tornado norma com relativa facilidade, através da Resolução $\mathrm{n}^{\circ}$ 7, de 18 de outubro de 2005, vedando, entre outras práticas, o exercício de cargo de provimento em comissão ou de função gratificada, no âmbito do Tribunal ou juízo, por cônjuge, companheiro ou parente, em linha reta, colateral ou por afinidade, até o terceiro grau, inclusive, dos respectivos membros ou juízes vinculados, bem como dos servidores investidos em cargo de direção ou de assessoramento.

Há quatro décadas, autores como Samuel Huntington e Joseph Nye chegaram a defender que a corrupção atuaria como facilitador em processos de modernização, contornando o excesso e as inadequações de leis e regulamentos, e criando uma ponte entre uma classe dirigente em ascensão e as elites econômicas pré-estabelecidas - típicas de nações em desenvolvimento - sem o que essas forças tenderiam a ser antagônicas e conflitantes (Huntington, 1968). Para Nye, a corrupção pode ser benéfica ao desenvolvimento político, se ela for um instrumento para a formação de capital privado, superação das barreiras burocráticas, integração das elites políticas e de capacidade governamental (Nye, 1967). Já mais recentemente, essa visão positiva da corrupção como “a graxa que faz o sistema andar" está sendo contestada. Economistas e estudiosos têm apontado a corrupção principalmente como entrave ao desenvolvimento econômico e social de uma nação, em muitos casos, o principal entrave. Em seu estudo para o Fundo Monetário Internacional, Paolo Mauro observa que "há um crescente reconhecimento de que a corrupção tem efeitos adversos substanciais sobre o crescimento econômico"

\footnotetext{
${ }^{5}$ Há várias interpretações da dicotomia público/privado. A adotada nesta dissertação, refere-se à propriedade dos bens em questão, se pública e estatal, ou privada das empresas, organizações da sociedade civil, famílias ou indivíduos.
} 
(2002, p. 1, tradução nossa). Isso se daria uma vez que altos níveis de corrupção inibem os investimentos pela inserção de fatores adicionais de incerteza, e levam a um governo ineficiente tanto pela incorreção das decisões políticas tomadas sob a influência da corrupção política, quanto pelo aumento dos custos desse processo de decisão (RoseAckerman, 1999). Não se trata apenas do custo dos valores pagos como propina a políticos e partidos quando ocorre a corrupção política. Naturalmente, esses montantes pagos pelos grupos interessados nas decisões tomadas são amplamente recompensados pelos ganhos privados decorrentes dessas decisões políticas. Esses ganhos, um múltiplo dos valores pagos em propina, é que se acumulam como ineficiências no sistema econômico. Treisman compartilha a visão de que níveis elevados de corrupção política possam afastar investimentos e dificultar o crescimento econômico (2000), porém observa que alguns países têm crescido rapidamente nas últimas décadas apesar da percepção de que seus Estados foram altamente corruptos nesse período - China, Índia, Tailândia e Indonésia são exemplos disso (Treisman, 2007). Como resultado da corrupção, os serviços públicos e os investimentos feitos pelo governo se tornam mais caros aos cofres públicos e, portanto, sobram menos recursos públicos para investimentos, melhoria ou expansão desses serviços.

Sobre as limitações objetivas da responsividade de um governo para com seus cidadãos, Leonardo Morlino chama atenção para uma ordem de limites "conformada pelos recursos que um governo tem à sua disposição para responder às necessidades dos cidadãos" (Morlino, 2009, p. 215, tradução nossa). Nesse contexto, vejamos um exemplo simples: a pavimentação de uma via pública, feita sob a influência de um esquema de corrupção política, custa muito mais cara ao erário. Se neste exemplo consideramos que os recursos orçamentários são limitados e fixos, o resultado do sobrepreço são menos quilômetros asfaltados do que seria possível entregar à população se não houvesse corrupção, e, portanto, menor responsividade. Há, entretanto, outro aspecto do impacto da corrupção política a ser considerado, a sua influência sobre a definição das prioridades dos gastos públicos. Em casos como o do exemplo acima, talvez mais grave do que os quilômetros que ficaram por asfaltar, seja a informatização da escola ou a contratação de médicos adicionais para o posto de saúde que não foram concretizadas com aquela verba orçamentária e que poderiam ser prioridade para aquela comunidade. O fato para o qual se quer chamar a atenção é o de que a corrupção política influencia a forma como as prioridades orçamentárias de um governo são estabelecidas, de maneira a beneficiar 
empresas interessadas mais em certo tipo de gasto público que em outro e dispostas a pagar por esse benefício, tendendo assim a criar prioridades de governo em desalinho com as preferências da maioria dos cidadãos ${ }^{6}$. Conforme destacam Larry Diamond e Leonardo Morlino,

nenhum governo consegue por muito tempo ser responsivo a todas as diferentes demandas dos principais constituintes por serviços, benefícios e outros programas de despesas. Governar responsavelmente - em oposição a apenas responsivamente - envolve definir prioridades e fazer escolhas difíceis. Um dos mais importantes aspectos da responsividade em uma democracia é inferir da cacofonia de compromissos de políticas, resultados eleitorais e demandas de grupos de interesse precisamente quais são as prioridades do "eleitorado" (Diamond e Morlino, 2005, p. xxx, tradução nossa).

Filgueiras sugere que essa distorção nos gastos públicos e essas perdas ou custos adicionais levam a um aprofundamento das desigualdades sociais, à medida que "a fatia maior dos ganhos é acumulada pelos vencedores nos esquemas de corrupção, deixando a base social com uma fatia menor. O Estado, para compensar as perdas com impostos e taxas, aumenta impostos e taxas ou corta gastos essenciais, especialmente nas políticas sociais" (Filgueiras, 2008-b, p. 161).

Um exemplo do reconhecimento do impacto negativo da corrupção política na eficiência da economia pode ser encontrado no princípio de tolerância zero adotado como central pelo modelo desenvolvimentista de Cingapura, o qual foi justificado pela argumentação de seu mentor, Dr Goh Keng Swee ${ }^{7}$, segundo a qual a corrupção adicionaria custos, tornaria a economia nacional menos competitiva, e erodiria a moral e a fibra intelectual do serviço civil que deve criar, implementar e monitorar políticas desenvolvimentistas.

\footnotetext{
${ }^{6}$ Um exemplo disso foi o escândalo desvendado pela operação Sanguessuga da Polícia Federal em maio de 2006, quando veio à tona o esquema operado por uma quadrilha que envolvia prefeitos e secretários nos municípios, executivos do ministério da saúde, e parlamentares que manipulavam o orçamento no Congresso Nacional para assegurar verbas aos municípios que fraudassem licitações para aquisição de ambulâncias super faturadas. Diante da facilidade de ganhos pessoais, os prefeitos priorizavam essas aquisições, desconsiderando as prioridades do município ou do ministério, distorcendo assim a responsividade desses governos. Conforme notícia veiculada no jornal O Estado de São Paulo em 11 de dezembro de 2006, consultada em 07 de janeiro de 2011 no endereço http://www.estadao.com.br/arquivo/nacional/2006/not20061211p60113.htm.

${ }^{7}$ Dr Goh Keng Swee foi o segundo primeiro ministro de Cingapura entre 1973 e 1984, e um membro do parlamento Kreta Ayer por um quarto de século.
} 
Contudo, ainda que sejam importantes os desdobramentos econômicos da corrupção política - o que reforça a relevância do tema em si - o viés analítico desse estudo se concentra nos desdobramentos políticos do fenômeno, uma vez que se deseja examinar o seu impacto para a responsividade como dimensão da qualidade da democracia e para o accountability vertical.

Essa dissertação pretende demonstrar que a corrupção política é por natureza contrária à responsividade dos governos às preferências da maioria dos cidadãos. Isso porque, através de sua prática, são favorecidas as preferências de uma elite minoritária que paga pela sobrevalorização dos seus interesses em detrimento da maioria. Em sua avaliação de fatores que impactam a responsividade, Diamond e Morlino enfatizam essa tese, ao afirmar que

a responsividade pode ser restringida (...) quando o processo de formação e implementação de políticas fica distorcido por corrupção óbvia e o poder de lobby desproporcional de grupos de interesses abastados que contribuem pesadamente para partidos políticos (2005, p. xxxi, tradução nossa).

Os recursos financeiros angariados pelos políticos através da corrupção, quando utilizados para o financiamento de campanha, aumentam as chances desses atores se manterem no poder. Como ressalta Mauro Campos, "a presença irrestrita e desigual de recursos financeiros no processo eleitoral pode reforçar a desigualdade de competição" (2009, p. 16-17).

Com efeito, passados trinta anos da chamada terceira onda de democratização, a atenção dos estudiosos da democracia já não está tão voltada para a transição a regimes democráticos ou para a sua consolidação e estabilização, como aconteceu nos anos 90. "Como vários comentaristas e estudiosos apontaram, a democracia triunfou e é a única alternativa" (Morlino, 2009, p. 211, tradução nossa). Porém muitas dessas democracias, não tão novas, seguem altamente imperfeitas ou incompletas, a exemplo de países como a Rússia, no leste europeu, a Venezuela, na América Latina ou o Paquistão, no oriente médio. Isso tem levado cientistas sociais e praticantes da democracia a voltar sua atenção para os meios de avaliar a qualidade da democracia. Pipa Norris observa que no final do século 20, a maior preocupação é com a qualidade dos governos democráticos nas semidemocracias, e não tanto com sua persistência e estabilidade (Norris, 1999). Assumindo a 
democracia como um bem moral, se não mesmo um imperativo de bem estar e realização das pessoas, aumentar a sua qualidade no sentido do pleno estabelecimento da liberdade e da igualdade tornou-se meta desejável de bom desempenho a ser adotada na avaliação das instituições democráticas.

A abordagem da qualidade da democracia foi proposta por Diamond e Morlino, entre outros. Esses autores selecionaram oito dimensões para avaliação da qualidade democrática: primado da lei, accountability vertical, responsividade, liberdade, igualdade, participação, competição e accountability horizontal. Os autores sugerem que essa lista não é completa e definitiva, e reconhecem como possíveis dimensões adicionais, não incorporadas por eles, a transparência e a eficácia da representação (Diamond e Morlino, 2005). Essa classificação não cria, entretanto, dimensões estanques e independentes. Ao contrário, os diferentes aspectos da qualidade democrática integram e se sobrepõem. Diamond e Morlino sugerem que

a qualidade democrática pode ser pensada como um sistema, no qual melhorias em uma dimensão podem ter benefícios difusos em outras (e vice versa). Ao mesmo tempo, entretanto, há por vezes tradeoffs entre as diferentes dimensões da qualidade democrática, e é impossível atingir cada uma a seu nível máximo (2005, p. x, tradução nossa).

Sem ignorar as demais dimensões, o conceito de responsividade de Robert Dahl permite formular o processo de avaliação do funcionamento dessas instituições democráticas, visando resumir nessa, com alguma simplificação, as diversas dimensões da qualidade da democracia. Em seu livro, Diamond e Morlino, ao mesmo tempo em que dão destaque para a participação e para a competição como os motores da democracia, destacam a responsividade como "a dimensão dos resultados" (2005, p. xxix, tradução nossa). Bingham Powell argumenta que "a responsividade é uma das justificações para a própria democracia" (2005, p. 62, tradução nossa). O autor define responsividade democrática como sendo "o que ocorre quando o processo democrático induz o governo a formular e implementar políticas que os cidadãos querem" (Powell, 2005, p. 62, tradução nossa). Anos mais tarde, em seu tratado sobre legitimidade e qualidade da democracia, Morlino identificou três diferentes noções para a definição de qualidade de um produto, baseadas em processos, em conteúdo ou em resultado, e optou por essa terceira noção, focada nos resultados, para resumir o que considera uma democracia de qualidade. Em suas palavras: "uma boa democracia é primeiro e antes de tudo um regime amplamente 
legitimado que satisfaz os cidadãos (qualidade em termos de resultados)" (Morlino, 2009, p. 213, tradução nossa). Continuando, o autor sugere que quando se trata de avaliar democracias representativas,

a responsividade - um componente chave na experiência da democracia representativa - pode razoavelmente se tornar uma dimensão realmente central, à medida que ela torna possível averiguar a compatibilidade entre decisões tomadas, aquelas realmente implementadas e as necessidades explícitas e não explícitas dos cidadãos e da sociedade em geral (Morlino, 2009, p. 214, tradução nossa).

A influência do poder econômico sobre o processo de decisões políticas na esfera pública, quando acontece sob a forma de corrupção política, em que partes interessadas remuneram diretamente atores políticos por suas decisões públicas, tem viés contrário aos princípios democráticos e efeito nocivo sobre a qualidade da democracia, porque afeta a dimensão da responsividade. Isso não se dá apenas em consequência do desequilíbrio representativo em que esse mecanismo implica, mas principalmente pela ausência de transparência e impossibilidade de debate, reduzindo ou mesmo anulando o peso dos demais setores da sociedade no processo decisório, em benefício dos interesses privados de um grupo extremamente diminuto e pouco representativo da mesma. Nesse sentido, a corrupção política faz com que preferências da maioria dos cidadãos não sejam consideradas. Essa desconsideração pode levar à alienação e ao desinteresse dos cidadãos pela política, à medida que não se percebam alternativas viáveis, com grande prejuízo para a participação política, que é um dos motores da democracia.

Tendo-se em conta a consideração de que a corrupção política tem efeito negativo sobre a responsividade dos governos às preferências da maioria dos cidadãos, torna-se necessário indagar sobre o funcionamento das instituições democráticas voltadas a resguardar e maximizar essa responsividade, em particular o accountability vertical que é o mecanismo através do qual os eleitores poderiam punir os atores políticos que agem em desacordo com suas preferências.

Estudiosos do tema sugerem que a dinâmica do accountability vertical se estende para além das eleições ou da inter-relação entre eleitores e seus representantes eleitos, abrangendo também os esforços de associações civis, ONG's, movimentos sociais e a mídia de massa para manter o governo accountable nos períodos entre eleições (Diamond e Morlino, 2005). Para efeitos desse estudo será dado foco principalmente ao componente 
eleitoral do accountability vertical, avaliando seus desdobramentos para a responsividade e a qualidade da democracia e investigando os impactos da corrupção política sobre seu funcionamento eficaz. Conforme defende Luis Felipe Miguel,

O ponto culminante da accountability vertical é a eleição - que, assim, ocupa a posição central nas democracias representativas, efetivando os dois mecanismos centrais da representação política democrática, que são a autorização, pela qual o titular da soberania (o povo) delega capacidade decisória a um grupo de pessoas, e a própria accountability (Miguel, 2005, p. 27).

Essa escolha se justifica por três razões. Em primeiro lugar, por ser 0 accountability vertical um dos alicerces fundamentais de qualquer democracia. Embora não exista consenso quanto a uma lista definitiva de pré-requisitos mínimos para definir a democracia, pode-se afirmar que sem que existam eleições competitivas e periódicas nas quais os cidadãos sejam livres para votar e serem votados, um dado regime não pode ser considerado uma democracia (O’Donnell, 2005). Se analisarmos os atributos mínimos apresentados por muitos autores para que um regime seja considerado uma democracia, veremos que três deles estão intimamente ligados ao accountability vertical: 1) sufrágio adulto universal; 2) eleições recorrentes, livres e competitivas; 3) mais de um partido político sério; e 4) fontes alternativas de informação (Dahl, 1977). Segundo Diamond e Morlino, em democracias representativas

o accountability vertical se torna a dimensão verdadeiramente central, à medida que fornece aos cidadãos individuais e aos atores da sociedade civil organizada os meios de controle sobre políticos e instituições políticas. (Diamond e Morlino, 2005, p. xiii, tradução nossa).

Em segundo lugar, porque a realização de eleições em períodos previamente determinados é o mecanismo pelo qual os atores políticos prestam contas de seus atos políticos a seus eleitores e são por eles aprovados ou reprovados por sua atuação. É o momento em que o poder político é retirado de uns e delegado a outros pelos eleitores, que julgam as ações e escolhas dos atores políticos, agora na posição de candidatos, comparando-as às suas próprias preferências. Nesse contexto, a prática da corrupção política, ao afetar o modo como o sistema político processa as preferências da maioria, em benefício dos interesses de uma minoria que paga pelo privilégio, deveria reduzir as chances de um ator político, indivíduo, grupo ou partido ser aprovado pelos eleitores nas urnas, pelo menos naquelas situações em que tais práticas corruptas ou suas 
consequências para a responsividade fossem percebidas pelos cidadãos. Como observa Jairo Nicolau, "na versão tradicional, as eleições seriam um momento privilegiado de punir ou recompensar os responsáveis pelo governo: bons governantes seriam reconduzidos ao poder, enquanto os ineficientes seriam afastados" (Nicolau, 2002, p. 219).

Terceiro, porque o que se observa na prática parece contrariar a lógica descrita na segunda justificativa de relevância acima, à medida que atores praticantes da corrupção política não são punidos pelos eleitores de forma consistente. Isso suscita questionamentos no sentido de uma melhor compreensão desse fenômeno. Na raiz desse problema podem estar os altos custos do processo eleitoral, combinados à tolerância de parte do eleitorado à corrupção política, como sugerem Alberto Almeida (2006-b) e José Álvaro Moisés (2008-c), e sua resposta positiva aos investimentos feitos em marketing político ${ }^{8}$ pelos candidatos. A conexão entre os recursos financeiros oriundos de corrupção política e o financiamento de campanha se daria pelo uso do mecanismo de Caixa 2 de campanha, explorado mais à frente neste estudo. Essa combinação de fatores estaria criando uma demanda competitiva por recursos financeiros intensivos, que funcionaria como incentivo para os atores políticos adotarem a prática da corrupção política, como forma de angariar fundos para fazer frente a ela. Segundo Campos,

o dinheiro representa cada vez mais um importante ingrediente para o sucesso eleitoral, e os partidos, assim como os candidatos, necessitam, a cada campanha, de mais dinheiro, a fim de obterem sucesso em suas disputas eleitorais (2009, p. 16).

A questão da responsabilização do ato corrupto - e a consequente punição do ator político que o pratica - pelo eleitorado através do voto só é possível quando tal ato seja conhecido pelo eleitor, embora isso não seja uma garantia de que ele irá fazê-lo. O acesso, a absorção e a retenção dessa informação têm, portanto, importância central no processo de accountability. As instituições democráticas dedicadas ao monitoramento, denúncia e punição dos atores políticos, como o parlamento, a oposição e a justiça, amparadas por uma mídia de massa que goze da liberdade de imprensa, são responsáveis pelo accountability horizontal. Philippe Schmitter observa que

\footnotetext{
${ }^{8} \mathrm{O}$ conceito de marketing político encontra-se discutido em mais detalhes na seção 3.4. do capítulo 3.
} 
alguns esteios do accountability horizontal (...) intervêm nas relações executivo-legislativo-judiciário para prover um accountability 'de fora'. Essas agências 'guardiãs' (para usar um termo de Robert A. Dahl) podem incluir escritórios de auditoria, inspetores gerais e oficiais da ouvidoria, bem como uma gama de agências regulatórias independentes (Schmitter, 2005, p. 24, tradução nossa).

O bom funcionamento desses mecanismos é tão importante para a democracia que o accountability horizontal é considerado uma das oito dimensões da qualidade da democracia elencadas por Diamond e Morlino (2005). Powell justifica sua importância observando que "accountability horizontal (quando uma parte do governo responde à outra) gera força pela dispersão do poder, pelo menos para monitorar se os cânones do devido processo legal estão sendo observados" (2005, p. 71, tradução nossa).

A julgar pela constante veiculação de notícias de corrupção na mídia brasileira, muitas delas com origem em órgãos de controle como a Polícia Federal ou o Ministério Público, pode-se pensar que o accountability horizontal está cumprindo seu papel de informar, ainda que isso nada diga da eficácia dos supostos mecanismos punitivos que deveria embutir. Supondo-se, portanto, que o eleitor tenha alguma informação quanto à prática de corrupção política, o accountability vertical deveria operar mecanismos capazes de punir os atores políticos que a praticam, levando-os a perder o poder político pela rejeição do eleitorado, pelo menos nos casos em que tais práticas fossem percebidas por parcela expressiva dos eleitores como ilegais ou lesivas aos seus interesses. Entretanto, não parece ser isso o que se observa no Brasil, onde os eleitores têm se mostrado tolerantes aos indícios de corrupção política, não punindo seus perpetruadores na hora de votar (Moisés, 2008-c).

A essa tolerância soma-se a resposta positiva dos eleitores ao marketing político, o que motiva os candidatos a investirem recursos financeiros em suas campanhas. $\mathrm{Na}$ hora de votar, os eleitores brasileiros parecem privilegiar os candidatos que mais arrecadam fundos de campanha e que, consequentemente, mais gastam em propaganda eleitoral, mesmo diante das evidências da vinculação desses recursos com a compra explícita de serviços prestados por detentores do poder público a indivíduos ou grupos pertencentes a uma minoria financeiramente privilegiada, através da corrupção política.

Por se tratar de um processo competitivo entre atores interessados em ascender ao ou manter o poder político, os gastos ou investimentos em campanha feitos por um 
concorrente aumentam a pressão para que os demais também o façam, em um fenômeno que se retro-alimenta de forma semelhante a uma corrida armamentista. Segundo André Marenco,

o desenvolvimento técnico de sondagens de opinião pública, recursos de propaganda eleitoral e da tecnologia dos meios de comunicação tornou-se indispensável a campanhas partidárias competitivas, exponenciando os custos exigidos para alcançar os eleitores em disputa (Marenco, 2008, p. 382).

\section{Bruno Speck critica a}

possível distorção da competição eleitoral pelo peso dos recursos financeiros em campanhas ou pela distribuição desses recursos entre os competidores. (...) A acusação se refere ao encarecimento das campanhas eleitorais como indicador de uma crescente manipulação do eleitorado pelas modernas técnicas de propaganda (Speck, 2006, 154).

A consequente necessidade de recursos financeiros expressivos para eleger-se influi grandemente no comportamento dos atores políticos nos períodos entre eleições.

O caráter de centralidade existente na relação entre dinheiro e eleições (ou dinheiro e política) demonstra que não se trata de uma relação conjuntural existente apenas em períodos específicos. Trata-se de um 'nexo natural', que se caracteriza por uma composição de conflito, estendendo-se para além dos períodos eleitorais (Campos, 2009, p. 17).

Embora agir e decidir em concordância com as preferências da maioria do eleitorado devesse render aprovação e assim votos aos candidatos, isso pode não bastar para reeleger-se ou eleger a seus co-partidários. Agir em desacordo com tais preferências através da prática da corrupção política pode assegurar acesso a recursos financeiros importantes que rendem muito mais votos quando bem aplicados às campanhas eleitorais, ainda que possa ser necessário ocultar sua origem. Esse fenômeno se multiplica e solidifica quando se considera a prática de intercâmbio de apoio político entre candidatos e partidos, seja na busca de acesso a palanque ou tempo de propaganda eleitoral gratuita.

Almeida conclui que os eleitos preferem muitas vezes ser mais fieis ao poder do que aos eleitores (Almeida, 2006-b). Campos elabora que

a diversidade de fontes de estímulos e incentivos às estratégias dos atores políticos se estabelece através de jogos em múltiplas instâncias, o 
que permite associar as ações a diversas arenas, com playoffs variados. Se o jogo é aninhado (nos termos de George Tsebelis ${ }^{9}$ ), as preferências dos representantes podem ser influenciadas, em alguma medida, pelas preferências dos seus doadores privados (Campos, 2009, p. 15).

Ribeiro observa que

essa nova corrupção não beneficia necessariamente o bolso do corrupto, mas um projeto político que pode até ser justo e honrado. E o terrível é que se torna quase a única maneira de sobreviverem mesmo os honestos (Ribeiro, 2006, p. 79).

Esse autor aponta para o surgimento daquilo que chama "corrupção pósmoderna",

fruto da busca do poder pelo poder, que, portanto, se auto-alimenta, porque a praticam grupos que têm por finalidade principal reeleger-se e assim necessitam de recursos pingues ${ }^{10}$ para serem competitivos no próximo pleito (Ribeiro, 2006, p. 79).

Um desdobramento possível dessa observação é o de que a corrupção política, enquanto instrumento de manutenção do poder através da competitividade nos pleitos decorrente da disponibilidade de dinheiro extra para se investir em marketing político, tem em si um mecanismo de motivação do ator político para a sua prática. Mauro propõe que uma possível explicação para a persistência da corrupção associada à lentidão do crescimento econômico, argumentando que "quando a corrupção é amplamente espalhada, os indivíduos não têm incentivos para combatê-la mesmo se todos estivessem melhor sem ela" (Mauro, 2002, p. 1, tradução nossa). O autor exemplifica que seria muito difícil para um funcionário público negar ofertas de suborno em troca de favores públicos em um ambiente onde todos fossem corruptos, inclusive seus superiores, pois mesmo esses poderiam esperar uma parcela do suborno para eles próprios.

O encadeamento de fenômenos descritos acima e o conjunto de incentivos sobre os atores políticos dele decorrentes sugere uma vertente antidemocrática do processo eleitoral brasileiro, ainda que pareça haver um certo consenso positivo ao redor da qualidade democrática das eleições brasileiras, refletido nas observações de Matthew Taylor, para quem "o processo pelo qual os eleitores participam do processo de votação,

\footnotetext{
${ }^{9}$ Sobre o conceito de nested games, ver TSEBELIS, George. Nested games:rational choice in comparative perspectives. University of California Press, Berkeley/Los Angeles, 1990.

${ }^{10}$ Férteis, abundantes.
} 
supervisionados pela Justiça Eleitoral, beneficia-se de alta taxa de credibilidade" (Taylor, 2006, p. 149), e na pesquisa Democracy index 2010, Democracy in retreat da revista The Economist (2010) que deu nota 9,58 em uma escala máxima de dez para a categoria “processo eleitoral e pluralismo”. Segundo Campos

\begin{abstract}
se as eleições são realmente mecanismos eficazes de accountability, ao mesmo tempo são, em alguma medida, unaccountable, dadas as distorções que proporcionam, em função do mecanismo de financiamento eleitoral e de uma aparente fragilidade institucional para identificar, punir e coibir episódios ímprobos, na relação entre dinheiro e política (Campos, 2009, p. 211).
\end{abstract}

Segundo Ronald Hartlyn, "As eleições são a vida da democracia, mas nem todas as eleições são democráticas" (Hartlyn e McCoy, 2006, p. 41, tradução nossa).

Com efeito, pelo mecanismo sugerido, parte dos recursos financeiros arrecadados com a prática da corrupção política alimentariam o financiamento das campanhas eleitorais de candidatos ou partidos que a praticam, a fim de serem gastos na conquista dos eleitores e de seus e votos nas eleições.

Segundo Speck,

por financiamento de campanhas eleitorais entendem-se os recursos materiais empregados pelos competidores em eleições populares (partidos e candidatos) para organizar a campanha e convencer os cidadãos a lhes conferirem o voto. (...) Não compreende 0 financiamento ordinário das organizações partidárias ou a remuneração dos representantes eleitos, apesar de ambas as fontes terem muitos vasos comunicantes com o financiamento de campanha (2006, p. 153).

Esse financiamento é composto, de um lado, por doações ou contribuições de campanha e, de outro, por gastos de campanha. No acumulado de uma dada campanha eleitoral, a diferença entre as doações e os gastos forma as sobras de campanha, se o resultado for positivo, ou as dividas de campanha se for negativo. A legislação eleitoral exige dos candidatos que tanto as doações quanto as despesas sejam declaradas através da prestação de contas de uma campanha no Tribunal Superior Eleitoral (TSE).

O Caixa 2 de campanha, como definimos, são os recursos materiais, sejam eles financeiros ou de outra natureza, utilizados para fazer frente aos gastos e necessidades de campanha, cuja origem verdadeira não seja declarada à justiça eleitoral na prestação de 
contas exigida pela lei. A especificidade de que a origem seja a verdadeira tem relevância nessa definição em função da existência de doadores laranja - pessoas físicas ou jurídicas que emprestam seus nomes e identificação para o registro de doações feitas com dinheiro que não lhes pertence efetivamente, assumindo assim a autoria de doações feitas por terceiros que preferem não se identificar. Desse modo, tais doações, embora declaradas à justiça eleitoral na prestação de contas, são classificadas como Caixa 2 de campanha, para efeito desse estudo.

A retribuição financeira dada por agente corruptor a um ator político por um ato de corrupção que o beneficie pode eventualmente se dar na forma de uma contribuição de campanha legalmente declarada para a justiça eleitoral. Speck observa que

essa relação de trocar apoio financeiro à campanha por benefícios aos financiadores, claramente, viola os deveres de representação e tem um ônus para a sociedade. Essas doações que compram acesso ao poder ou outras vantagens se aproximam da definição de corrupção (2006, p. $155)$.

Entretanto, pela definição adotada, essas doações não seriam classificadas como Caixa 2 de campanha. Não é de se esperar que seja regra, mas sim exceção, a possibilidade de doações lícitas servirem como pagamento a um ato ilícito de corrupção, uma vez que a publicidade da doação feita em concordância com a lei pode atrair a atenção para o benefício obtido pelo doador através do uso indevido do poder público. Como afirma Campos, "parlamentares julgam[guem] as próprias ações de acordo com as possíveis repercussões que terão, seja junto aos eleitores (...), seja aos seus doadores de campanha" (2009, p. 21). Assim sendo, a tendência é que essa retribuição dada pelo agente corruptor ao ator político pelo benefício obtido no uso indevido do poder público seja feita na forma de Caixa 2, já que, segundo Carlos Melo

o financiamento ilícito torna literalmente impossível saber quais são de fato os doadores e qual o peso relativo daqueles que são conhecidos, a partir da contabilidade oficial, na composição das receitas de uma campanha. Sem informação, o eleitor pode ajudar a eleger um representante que está, prioritariamente, a serviço de interesses que ele ignora quais sejam (Melo, 2008, p. 376).

Daí, a importância do fenômeno do Caixa 2 de campanha para o estudo da corrupção política, o que levou ao esforço descritivo proposto aqui sobre o tema, partindo de uma literatura tanto empírica quanto conceitual bastante escassa. De fato, a corrupção 
é difícil de ser estudada empiricamente (Treisman, 2000), pois tanto a corrupção política quanto o Caixa 2 de campanha a ela associado são muito difíceis de medir. Por sua natureza ilícita, nem o corrupto nem o corruptor dão conta de seus atos, e empreendem os esforços necessários para não deixar evidências do ocorrido. O uso de medições quantitativas de ocorrências de notícias de corrupção na mídia é desaconselhável, pois essas medidas sofrem considerável distorção em decorrência dos níveis variáveis de liberdade de imprensa no caso de estudos comparativos entre regimes. Além disso, há grandes flutuações na concorrência dessas com notícias relevantes no momento, sejam econômicas, policiais, desastres, esportes ou outras, dificultando assim estudos que objetivem análises temporais do fenômeno da corrupção através da mídia de massa. A incidência de casos de corrupção na justiça parece oscilar mais com a eficácia na fiscalização e combate do que com o nível de corrupção efetivamente praticado, sendo inclusive argumento comum na defesa de políticos do poder de que "não é que agora se rouba mais, é que agora se apura mais".

Na busca por alternativas, se tornou comum na literatura a adoção de índices que medem não a corrupção em si, mas sua percepção através de pesquisas de opinião, produzidos principalmente por ONGs como o "Corruption Perception Index", da Transparência Internacional e o "World Values Survey". Esses índices, por vezes referenciados nessa dissertação, são muito úteis em diversos casos, porém não abrangem o fenômeno do Caixa 2, e sua principal utilidade tem sido em comparações entre regimes de diferentes países, que não estão no foco deste estudo. Uma vez que sua granularidade é por país, o CPI não serve de base para estudos internos ao regime de um país, como seria necessário a uma pesquisa empírica ao redor dos fenômenos tratados neste estudo.

Em função disso, adotei uma proposta metodológica heterodoxa - compatível com as dificuldades empíricas de pesquisa do tema - que será baseada em observações descritivas dos fenômenos estudados a partir de depoimentos, notícias de jornal, e em alguns casos dados de pesquisa, quando existentes. Reconheço as limitações analíticas de tal opção, do ponto de vista acadêmico-científico, porém, dada a relevância do tema, o que se pretende aqui é dar uma contribuição inicial no sentido de maior conhecimento dos fenômenos analisados e abordados nesta dissertação e, ao mesmo tempo, no sentido de definir uma agenda de futuras pesquisas sobre o tema. Apesar da inviabilidade da confirmação empírica das hipóteses sugeridas ao longo desta dissertação, este estudo se 
faz relevante à medida que despeja uma luz sobre mecanismos possíveis e/ou prováveis na tentativa de explicar os fenômenos da corrupção política e do Caixa 2 de campanha, descartando hipóteses de ação logicamente irrelevantes. Essa redução do universo de possibilidades visa a facilitar a elaboração de metodologias de investigação que permitam um estudo empírico do tema no futuro. Além disso, a compilação da literatura apresentada permite uma visão conjunta e conexa de temas importantes para o objeto que são na prática interligados porém costumam ser tratados de forma isolada e estanque pela Ciência Política; comportamento eleitoral e qualidade da democracia, corrupção política e horário eleitoral gratuito, Caixa 2 de campanha e accountability vertical são alguns exemplos dessa contribuição. 


\section{Capítulo 2}

\section{Diálogo com o estado da arte}

Esse capítulo pretende abordar aspectos do debate corrente na literatura sobre a democracia que são relevantes para a reflexão sobre a corrupção política, os fatores que favorecem sua ocorrência e suas consequências para a qualidade da democracia.

\subsection{Corrupção política: definição e delimitações}

Conforme afirmado na introdução, adota-se aqui a definição de Daniel Treisman, segundo quem "a corrupção política se caracteriza pelo uso indevido do bem público para fins privados" (2000, p. 2, tradução nossa). De acordo com os objetivos desta dissertação, proponho adicionar a essa definição a menção a quem pratica a corrupção, ou seja, atores políticos eleitos ou agentes públicos por eles diretamente nomeados. A expressão "uso indevido" dessa definição é a tradução do original em inglês "misuse". Essa palavra e, mais ainda, a expressão adotada em sua tradução permite uma certa flexibilidade interpretativa em relação a quais padrões usar para se definir 'indevido'.

Fernando Filgueiras aponta para o aspecto central da normatividade na caracterização desse uso indevido. Ele afirma que, nas sociedades modernas, não se pode definir-se corrupção em termos morais, e justifica sua afirmação argumentando que 
não é possível haver consenso em torno de valores morais, fazendo com que o valor possa ser defensável, uma vez que sociedades complexas são, necessariamente, sociedades plurais, permeadas por doutrinas divergentes e razoáveis, as quais possibilitam diferentes tipos de julgamento por parte dos atores. (...) O desacordo tem por consciência a limitação das instituições para admitir valores. Em sociedades complexas, portanto, a ordenação ocorre por um consenso constitucional sobreposto, destinado a absorver as fontes do desacordo e dos juízos para processá-los no sentido da estabilidade, não se confundindo com um consenso efetivo originado dos atos de vontade. (...) Dizer, portanto, que certa ordem política é corrompida, ou que algum ator praticou um ato de corrupção significa mobilizar nessa asserção normas que estão no plano de consensos normativos, em torno de expectativas comportamentais (Filgueiras, 2008-b, p. 88-89, p. 92).

Arantes parece concordar com a relevância normativa, ao adotar uma definição centrada nos crimes de corrupção, que seriam

os casos em que o crime principal é a apropriação direta e malversação de fundos públicos ou fraude organizada e reiterada de atividades do Estado (autorização, concessão e/ou inspeção de interesses públicos, bens ou atividades econômicas), por agentes públicos (com ou sem envolvimento do setor privado) (Arantes, no prelo, p. 25, tradução nossa).

Gianfranco Pasquino, no Dicionário da Política (Bobbio, Matteucci e Pasquino, 2007), reforça a relevância do componente normativo na definição de corrupção, ao explicar que corrupção

designa o fenômeno pelo qual um funcionário público é levado a agir de modo diverso dos padrões normativos do sistema, favorecendo interesses particulares em troca de recompensa. Corrupto é, portanto, o comportamento ilegal de quem desempenha um papel na estrutura estatal (2010, p. 291).

Heloisa Starling sustenta uma visão distinta em sua análise contemporânea da obra Sereníssima República, ao observar que

sugeria Machado de Assis que a corrupção sempre provém da incapacidade dos homens (...) produzirem um mundo de significados comuns, vale dizer, produzirem um lugar, uma linguagem e uma história que lhes permitam criar as condições para partilharem um conjunto específico de valores e decidirem, com base nesses valores, 
sobre quais critérios aplicar diante da sua própria condição de insaciabilidade (Starling, 2008, p. 267).

Pode-se talvez explicar essa diferença de posicionamento pela época em que Machado de Assis escreveu seu conto político. Filgueiras observa que "a moral se separou da política na modernidade, demandando ao direito o papel de enunciação dos valores" (2008-b, p. 71), quer dizer, a corrupção já foi uma questão de valores morais e virtudes cívicas, antes de tornar-se um desvio das regras legais com o advento da modernidade. O autor reforça sua posição ao dizer que "é fato que a teoria política da corrupção está relacionada a fins normativos” (Filgueiras, 2008-a, p. 359). Ao levar-se em conta a centralidade das instituições, gera certa preocupação a observação de Mauro Campos de que "a despeito do desconforto que as crises envolvendo corrupção eleitoral provocam nas democracias, acabam sempre ganhando uma conotação muito mais moral e menos institucional" (2009, p. 206). Isso pode ser interpretado como um sinal de que as instituições dedicadas a fiscalizar o cumprimento das normas que regulam a corrupção podem não estar funcionando devidamente.

O outro aspecto da minha definição de corrupção que merece um esforço de contraste com a literatura é a questão dos atores envolvidos no ato corrupto. Para fins deste estudo, considera-se a participação de dois grupos de atores no fenômeno da corrupção: por um lado, os atores políticos ou agentes públicos por eles nomeados que praticam a corrupção, fazendo uso indevido de recursos públicos, e por outro os atores do setor privado que se beneficiam da corrupção e pagam aos primeiros por ela. Essa definição exclui do escopo do estudo atos de corrupção praticados entre entidades exclusivamente privadas, a exemplo, um funcionário de uma empresa privada que receba benefícios pessoais em troca de decisões que favoreçam outra empresa, sem o conhecimento nem a anuência de seus superiores ou do proprietário da empresa lesada por aquela decisão. De fato, a literatura de Ciência Política investigada parece sempre apontar para a necessidade do envolvimento do setor público, seja através de um ator político ou de um funcionário público para que se possa configurar um ato de corrupção. Arantes, em sua definição de crime de corrupção política, sugere que tal fato, que sempre tem a participação de um agente público, possa ocorrer "com ou sem envolvimento do setor privado" (Arantes, no prelo, p. 25, tradução nossa). Embora não tenham sido citados exemplos, pode-se imaginar uma situação em que órgãos de controle do setor público ajam de forma corrupta em favor de agentes públicos 
pertencestes aos órgãos controlados. Caberia uma discussão se o agente corruptor, nesse exemplo, age em busca de benefícios públicos, digamos para proteger a reputação e preservar os benefícios obtidos pelo órgão fiscalizado, ou se age primordialmente em benefício próprio, tentando esquivar-se de possíveis punições pessoais, e, portanto, agindo de forma privada. Outro possível exemplo é o caso em que líderes políticos do poder executivo paguem propina a membros do legislativo pela obtenção de apoio parlamentar. Ainda que haja um agente privado, empresa ou pessoa, atuando como intermediário desse esquema, efetivamente pode-se interpretar que o corruptor e o corrompido agem ambos em nome do governo, na esfera estatal.

Feitas essas considerações, para efeito deste estudo, vale a interpretação de Susan Rose-Ackerman para quem a corrupção ocorre nas interfaces dos setores público e privado, de acordo com sistemas de incentivo que permitem aos agentes políticos maximizarem utilidade mediante suborno e propina (Rose-Ackerman, 1999).

Já foi mencionada a importância que Samuel Huntington dá para a necessidade de que tanto o ator político quanto o cidadão comum tenham uma noção prévia da diferença entre papéis públicos e interesses privados para que possam identificar e reconhecer a existência de corrupção (Huntington, 1968). Newton Bignotto é mais abrangente, para além da corrupção, ao afirmar que "não há Estado de Direito e constituição sem que haja delimitação das fronteiras entre o domínio público e o domínio privado" (2006, p. 84). Esse reconhecimento requerido por Huntington seria uma conquista da modernidade, e alguns autores apontam para o fato de tal conquista não estar consolidada em todas as sociedades. José Álvaro Moisés argumenta que
diferente dos países modernizados pelo impacto de transformações econômicas e sociais, as nações com baixos níveis de desenvolvimento não conseguiriam institucionalizar a distinção entre as esferas pública e privada, legitimando a apropriação privada de recursos públicos (Moisés, 2010, 28).

Não se trata aqui de uma separação estanque. Na verdade, mesmo na modernidade e em sociedades desenvolvidas, não há uma separação total, porque o público lida com o privado o tempo todo, suas ações sempre se refletem sobre o privado. Mario Guerreiro e Alberto Oliva discordam da visão bastante disseminada na 
sociedade contemporânea de que as esferas pública e privada seriam departamentos estanques, defendendo que

são dois espaços dotados de fronteiras de difícil demarcação e que se mantêm em diuturnos e complexos processos de interação. (...) A esfera pública não apresenta uma descontinuidade em relação à esfera privada (Guerreiro e Oliva, 2006, p. 167-168).

Bignotto afirma que, no Brasil, "embora tenhamos uma rica história constitucional, a separação entre o público e o privado nem sempre é percebida como um fato derivado das leis fundamentais e nela refletidos" (2006, p. 84-85). Fernando Henrique Cardoso afirma que o uso privado dos recursos do Estado é característica do conservadorismo brasileiro, que "não é político, é de costumes, é social, é de cabeça" (Cardoso, 1998). Alberto Almeida observa que "o pensamento sociológico e antropológico brasileiro é praticamente unânime em apontar o caráter patrimonialista da política brasileira" (Almeida, 2006-b, p. 97). Embora ciente de que o reconhecimento e a consciência da separação das esferas pública e privada não sejam uniformes na sociedade brasileira, uma vez que a transição para a modernidade pode não ter se consolidado em todas as regiões e camadas sociais do nosso país, foi assumido que o Brasil é uma democracia razoavelmente consolidada, permitindo essa distinção de forma suficientemente clara para que a corrupção política possa ser tipificada e reconhecida.

\subsection{Fatores que influenciam os níveis de corrupção}

A literatura política, tanto a internacional quanto a brasileira, tem empreendido consideráveis esforços no sentido de identificar e mensurar fatores que favorecem ou inibem a incidência de corrupção. A primeira dificuldade enfrentada pelas pesquisas empíricas é a impossibilidade de medir a corrupção diretamente. Isso foi resolvido em 
diversos casos pela adoção da medida indireta de percepção da corrupção, obtida por pesquisa de opinião, como indicativo suficientemente fiel dos níveis reais de corrupção. É preciso reconhecer a subjetividade do uso da percepção em lugar de uma medição concreta do fenômeno em estudo e a controvérsia existente em torno de sua utilização na Ciência Política. Ao analisar as pesquisas sobre corrupção política, há que se ter em mente que as análises feitas se referem à percepção, e não ao fenômeno em si. O índice de percepção mais utilizado, embora não seja o único, é o "CPI - Corruption Perception Index", da organização Transparência Internacional ${ }^{11}$, organização global da sociedade civil que lidera a luta contra corrupção.

Em linha com a ideia central desta dissertação, as pesquisas referidas nesse capítulo abrangem fatores que favorecem a incidência de corrupção (ou em geral da percepção da mesma).

Os resultados das pesquisas comparativas conduzidas por Thimothy Power e Julio Gonzáles apontam que o tipo de regime tem correlação com o nível de corrupção política de um país. Teoricamente, os níveis de corrupção deveriam ser menores nos sistemas políticos mais democráticos e abertos, tanto pelo nível geralmente mais alto de transparência proporcionado pela poliarquia quanto pela competição, que incentiva os candidatos a cargos públicos a descobrirem e levarem a público abusos do cargo por seus atuais detentores (Power e Gonzáles, 2003). Entretanto, a pesquisa realizada por Treisman com vários países não encontrou relação estatística mensurável entre o fato de um país ser democrático no presente e o quão corrupto ele tende a ser percebido. Já países que foram democráticos por muito tempo foram percebidos como menos corruptos do que aqueles que não são democráticos ou o são há pouco tempo (Treisman, 2000). Leonardo Avritzer também observa que “em países de democratização mais recente ou praticamente sem experiência de democracia, a corrupção se expressa de forma muito mais intensa" (2008, p. 505). Essa constatação de Avritzer e as evidências empíricas de Treisman sugerem que a redução da corrupção está relacionada com a existência de democracia no longo prazo. Adicionalmente, as pesquisas indicam que os países com sistema presidencialista, principalmente o de eleições proporcionais de lista fechada, tem uma correlação com maiores níveis percebidos de corrupção do que os

\footnotetext{
${ }^{11} \mathrm{http} / / /$ www.transparency.org/policy_research/surveys_indices/cpi/2010, acessado em 21 de dezembro de 2010
} 
parlamentaristas (Treisman, 2007) e os estados federativos são fortemente percebidos como mais corruptos que os unitários (Treisman, 2000).

Ainda que os resultados de pesquisas estatísticas com múltiplos países não tenham apontado para um peso preponderante da cultura de um país nos níveis percebidos de corrupção, quando controlados por variáveis como desenvolvimento econômico e estabilidade da democracia (Treisman, 2000), muitos autores chamam a atenção para questões culturais de grande importância para o accountability vertical, a incidência de corrupção política e o funcionamento da democracia como um todo. "Não se pode assumir que fazer a democracia funcionar é uma simples questão de se ter os arranjos constitucionais corretos” (Inglehart e Welzel, 2005, p. 160, tradução nossa), pois os mesmos não teriam eficácia sem apoio e suporte que dependem de uma cultura de massa compatível com os valores democráticos. "A prática diverge dramaticamente das normas institucionais quando os valores prevalecentes de uma sociedade as contradizem, tornando-as irrelevantes" (Inglehart e Welzel, 2005, p. 160, , tradução nossa). Segundo Filgueiras,

a abordagem da cultura política afirma que os países protestantes tendem a ser menos corrompidos do que os países de tradição católica, uma vez que o comportamento daqueles tende a ser mais conducente à obediência de normas que o comportamento destes (Filgueiras, 2008a, p. 356).

Segundo William Mishler e Richard Rose, a corrupção é mais presente e mais amplamente aceita em algumas culturas que em outras. Onde seja esse o caso, a percepção de corrupção pode ser menos saliente e ter efeitos mais fracos sobre a confiança política e sobre o suporte ao regime, comparativamente com contextos em que a corrupção é menos culturalmente aceita (Mishler e Rose, 2005).

Outro aspecto cultural que contribui para a deterioração da eficácia do accountability vertical ${ }^{12}$ no combate à corrupção política é o baixo nível de interesse na política. Segundo pesquisa publicada por Almeida, em 2002, 50\% dos eleitores brasileiros disseram ter pouco interesse por política, 39\% disseram não ter interesse e apenas $11 \%$ disseram ter muito interesse. "O eleitor brasileiro é presa fácil da representação política. Ele não gosta de política e, por isso, a política gosta dele. Gosta e

\footnotetext{
${ }^{12}$ Discutida em mais detalhes no próximo capítulo
} 
usa como lhe convém" (Almeida, 2006-b, p. 56). Esse desinteresse não apenas favorece a corrupção política, mas pode ser consequência da mesma, uma vez que, segundo Starling,

a corrupção está diretamente associada à incapacidade institucional do experimento republicano conduzir à participação do cidadão na vida pública. (...) Perdida a condição de exercer participação ativa nos espaços políticos que constituem a base de sustentação de uma vida pública, perde-se o referencial comum, perde-se a identidade republicana (Starling, 2008, p. 271).

Almeida prescreve três medidas para reduzir a ocorrência do fenômeno que chama de "amnésia eleitoral", melhorando assim as perspectivas da eficácia do accountability vertical: o aumento do nível de escolaridade do eleitor brasileiro; o reforço do voto em partidos, e não no candidato; e, minimamente, a redução do número de candidatos (Almeida, 2006-a). Rennó aponta que quando o eleitor simpatiza com algum partido, seu nível de conhecimento sobre a política tende a aumentar, pois passa a usar o partido como fonte de informação sobre o posicionamento político dos candidatos (Rennó, 2006). Assim, quanto maior a identificação partidária, menor a influência dos gastos de campanha sobre a proporção dos votos (Almeida, 2006-b).

O acesso a distintas fontes de informação, condicionadas pelas predisposições ideológicas dos eleitores, diminui a incerteza quanto às preferências políticas dos candidatos. A expectativa é de que eleitores mais ideologizados devam ter mais informação sobre os candidatos, já que ideologia é um indicativo do interesse do eleitor por política e de sua capacidade de se orientar na identificação da postura dos distintos candidatos (Rennó, 2006).

Pesquisas globais realizadas com os dados da CPI (Índice de Percepção da Corrupção) 2000 confirmam que a riqueza total de um país medida pelo PIB tem forte correlação inversa com os níveis de percepção da corrupção (Power e Gonzáles, 2003). Entretanto, a distribuição de renda não apresenta forte correlação com a corrupção, como se poderia pensar. Moisés observa que quanto mais alto o nível de desenvolvimento econômico e social de uma nação, menor o nível de comportamento corrupto (Moisés, 2008-c), convergindo com a afirmação de Treisman de que presumivelmente isso se dá através da racionalização dos papéis públicos e privados e da disseminação da educação que torna os abusos mais difíceis de esconder (Treisman, 
2000). Se por um lado essa progressão parece favorecer essa trajetória evolutiva, por outro pode-se pensar que o desenvolvimento de uma sociedade e sua classe política leve à sofisticação dos mecanismos de corrupção política, resultando em maior eficiência na elaboração de uma aparência legal às práticas corruptas. De todo modo, segundo Almeida, tudo indica que, com o inevitável aumento da escolaridade do cidadão brasileiro, em duas décadas o eleitorado será bem menos estatizante e bem menos tolerante ao patrimonialismo do que é hoje (Almeida, 2006-b). Ainda que pareça uma tese de difícil confirmação científica, Helio Jaguaribe defende que

somente uma revolução educacional poderá instituir no Brasil uma competente democracia de massas, como na Europa ocidental. Isso requer, além de outras coisas, um largo espaço de tempo. Enquanto não se logre um satisfatório nível educacional para o Brasil, somente uma reforma política (...) proporcionará ao país um nível mínimo de capacitação política (2006, p. 19).

Uma vez que não se pode esperar de um congresso eleito clientelisticamente que se disponha a adotar reformas que inviabilizariam a eleição da maior parte dos atuais parlamentares, o autor acredita que somente por vias plebiscitárias se poderá empreender a necessária reforma política. Tal possibilidade "dependerá de que venha a ser eleito um candidato à Presidência da República cujo programa contenha a reforma política em questão e que efetivamente se disponha a implementá-la" (Jaguaribe, 2006, p. 19).

Treisman observa que alguns autores acreditam que o desenvolvimento econômico explica por que certos países adquirem boas instituições; outros acreditam que as boas instituições é que explicam uns países serem mais desenvolvidos que outros; já um terceiro grupo acredita que o acúmulo de capital humano causa ambos: desenvolvimento econômico e instituições políticas superiores (Treisman, 2007). Tanto a observação desse autor quanto as demais pesquisas discutidas neste capítulo enfrentam o desafio de explorar fenômenos e processos cujas possíveis relações de causalidade são muito complexas, constituídas por múltiplos fatores e dimensões em interações multidirecionais. Isso faz com que as previsões de trajetórias, ainda que plausíveis e pautadas em realidades concretas, não sejam as únicas possíveis, como se viu acima na sugestão da possibilidade de aumento da sofisticação nas práticas de corrupção associadas ao desenvolvimento da sociedade. 


\subsection{Efeitos da corrupção sobre a qualidade da democracia}

A qualidade da democracia, conforme discutida no capítulo anterior, e segundo Larry Diamond e Leonardo Morlino, pode ser avaliada através de oito dimensões: primado da lei, accountability vertical, responsividade, liberdade, igualdade, participação, competição e accountability horizontal. Dentre estas, nesta dissertação adota-se a responsividade como dimensão central da qualidade democrática, enquanto os autores elencam a participação e competição como os motores da democracia, por sua capacidade transformadora de um regime. Cabe relembrar que essa lista não é finita e que os diferentes aspectos da qualidade democrática integram e se sobrepõem, conforme elaboram Diamond e Morlino (2005).

Vários autores discutem os impactos da corrupção sobre a democracia. Moisés aponta para a abrangência dos efeitos da corrupção para além das relações diretas com o Estado, ao afirmar que

os efeitos da aceitação da corrupção afetam a qualidade da democracia: diminuem a adesão ao regime, estimulam a aceitação de escolhas autoritárias, influenciam negativamente a submissão à lei e a confiança interpessoal, e inibem tendências de participação política (Moisés, 2010, p. 35).

Segundo Bignotto, "a corrupção é tida como um problema para a sociedade brasileira, em grande medida, porque é percebida como parte da nossa vida política em toda a sua extensão e não apenas em uma de suas dimensões" (Bignotto, 2006, p. 83). Nesse sentido, o autor chama atenção para um aspecto mais abrangente da corrupção, que "afeta a relação dos cidadãos de um Estado com a vida política em geral e não apenas com uma de suas instâncias mais facilmente identificáveis" (2006, p. 83), que é o Estado.

Filgueiras lista quatro efeitos da corrupção sobre a democracia (Filgueiras, 2008b, p. 159):

a)a deslegitimação das instituições democráticas; 
b)a crescente desconfiança para com a elite política;

c)a fundamentação de desigualdades sociais;

d)a centralização excessiva pela criação de uma elite política que se reproduz no poder.

É possível traçar um paralelo entre os quatro efeitos listados por Filgueiras e algumas das oito dimensões da qualidade da democracia de Diamond e Morlino. A legitimação está intimamente ligada à responsividade; a desconfiança leva a não participação; as desigualdades sociais afetam a igualdade entre os cidadãos, e por fim a centralização excessiva de poder afeta a competição e, assim, o accountability vertical.

\subsubsection{Legitimidade e responsividade}

A questão da legitimidade merece uma atenção especial, pelos pontos de contato que tem com a responsividade, adotada como dimensão central da qualidade da democracia nesse estudo. Em seu recente texto sobre legitimidade e a qualidade da democracia, Morlino chega a sugerir que "talvez o modo mais eficaz de medida da dimensão de responsividade seja examinar a legitimidade do governo, ou a percepção de responsividade dos cidadãos, ao invés da realidade" (2009, p. 215, tradução nossa). Pela definição do autor,

legitimidade é um conjunto de atitudes sociais positivas para com instituições democráticas, que são consideradas a mais apropriada forma de governo. (...) Há legitimidade quando há uma crença amplamente difundida entre os cidadãos de que, apesar das lacunas e falhas, as instituições políticas existentes são melhores do que quaisquer outras que pudessem ser estabelecidas (Morlino 2009, p. 211, tradução nossa). 
Já Filgueiras ressalta a importância dos consensos normativos, que "expressam os valores fundamentais da moral da política, que asseguram a legitimidade do sistema" (2008-b, p. 142), ao apontar um

ponto comum às teorias democráticas do século XX: a legitimidade do regime democrático é construída com base na existência de regras constitucionais estáveis, conforme o suporte dado pelos eleitores, mediante eleições regulares e limpas. Ou seja, a legitimidade da democracia só é possível a partir de um modelo formal (Filgueiras, 2008-b, p. 147).

Morlino reforça a associação da responsividade com a legitimidade explicando sua pressuposição de que

e há responsividade, há também legitimidade, na forma de legitimidade específica ou satisfação; inversamente, a falta de responsividade implica em graus variados de insatisfação. Em outras palavras, a consequência empírica da responsividade é a legitimidade específica, e vice versa (Morlino, 2009, p. 215, tradução nossa).

Para Filgueiras, a corrupção “é a expressão da ilegitimidade, tornando-se mais comum nos momentos de crise" (2008-b, p.142).

\subsubsection{Confiança e participação}

Enquanto Morlino constrói essa bivalência apresentada acima entre legitimidade e responsividade, Filgueiras sugere uma relação causal entre desconfiança e perda de legitimidade. Segundo o autor,

Caso não haja a construção de mecanismos de responsabilização dos políticos na institucionalidade democrática, o risco de crescente deslegitimação é grande. A corrupção contribui para uma crescente deslegitimação das instituições democráticas, ao reduzir a confiança depositada pelos cidadãos (Filgueiras, 2008-b, p. 160). 
Essa desconfiança que Filgueiras projeta principalmente sobre a elite política é apontada por alguns autores como tendo abrangência mais ampla, atingindo o próprio regime e as instituições democráticas. Segundo Moisés, “os resultados das pesquisas indicam que a corrupção é um dos fatores responsáveis pelo incremento da desconfiança dos cidadãos das instituições democráticas" (2010, p. 35-36).

Diamond e Morlino apontam que

o amplo declínio da confiança pública em instituições governamentais e políticas, e a percepção generalizada de que governos democráticos e políticos são cada vez mais corruptos, interessados em si mesmos e não responsivos são tendências comuns a muitas democracias, novas e velhas, e têm levado estudiosos proeminentes a falar de uma "crise da democracia" (Diamond e Molino, 2005, p. ix, tradução nossa).

Em seu estudo sobre os efeitos da corrupção na qualidade da democracia focado no caso do Brasil, Moisés se vale de modelos analíticos com alta capacidade de explicação para concluir que "quanto menos as pessoas confiam em instituições democráticas mais vêem a corrupção como parte do sistema político" (2010, p. 31).

Pippa Norris aposta que há no mundo uma crise de confiança nas instituições e regimes democráticos, constatada mesmo em democracias antigas e estabelecidas (Norris, 1999). Mishler e Rose apontam que há ainda mais razões para preocupação em regimes democráticos recentes e transicionais, semidemocracias parciais ou incompletas, altamente falhas, nos quais o ceticismo exagerado pode dificultar a consolidação e o avanço dessas democracias, uma vez que, segundo os autores, se faz necessária confiança em valores democráticos para que haja suporte a regimes democráticos, e para que se promova a qualidade e quantidade da participação (Mishler e Rose, 2005).

Uma desconfiança prolongada pode ter efeito sobre a crença nos valores democráticos em si. Moisés alerta que

se os cidadãos mostram-se incapazes de perceber que a corrupção existe e de compreender as implicações da corrupção para a democracia, ou se eles desqualificam o fato de ela ser objeto de contestação da mídia e da oposição política, é provável que a sua existência - e a sua continuidade no tempo - coloquem em questão os 
fundamentos do sistema democrático (Moisés, 2008-c, texto não publicado).

Embora o autor apresente essa especulação no plano exclusivamente conceitual, pode-se pensar em um possível exemplo concreto desse fenômeno, ainda que carente de uma confirmação empírica para sua validação: no caso da Venezuela, o apoio popular ao regime do presidente Hugo Chaves, em que valores fundamentais da democracia são colocados em segundo plano diante dos objetivos sociais da revolução socialista bolivariana, aconteceu após sucessivos regimes democráticos repletos de corrupção e agravamento das desigualdades sociais. Diamond e Morlino apontam para

a apatia dos cidadãos que duvidam da eficácia dos mecanismos democráticos, ou que foram alienados do processo democrático como resultado da baixa qualidade da democracia em outros aspectos (por exemplo, corrupção, abuso de poder e falta de competitividade). Naturalmente que tais falhas sistêmicas podem, sob as condições certas de revolta popular e mobilização cívica efetiva, gerar aumento na participação, mas na ausência de alternativas viáveis de reforma, elas induzem a uma retração cívica (Diamond e Morlino, 2005, p. xvii, tradução nossa).

Para Misher e Rose, faz-se necessário que haja confiança nas instituições para a sobrevivência e o funcionamento efetivo da democracia (2005). Segundo Norris, uma baixa performance de sucessivos governos democráticos poderia erodir a crença nos valores democráticos em si (Norris, 1999). Mishler e Rose apontam a má performance econômica e política de um regime como as principais causas de falta de confiança política de um povo nas instituições desse regime (2001). Embora a primeira seja tipicamente considerada a principal fonte, vem crescendo a atenção dada à performance política, que inclui a proteção de direitos civis, o estabelecimento do primado da lei e a redução da corrupção (Mishler e Rose, 2005). Mais especificamente para regimes democráticos novos ou transicionais, na opinião desses autores, a corrupção constitui o principal padrão de performance política. Sendo ou não o principal, é um padrão constante e muito disseminado desses regimes.

Com efeito, embora muito dificilmente a corrupção em democracias avançadas venha a erodir o apoio público à democracia como forma mais desejável de governo, há menos razões para se esperar esse compromisso inabalável com a democracia em países da América latina. Grande parte dos latino-americanos se mostram ambivalentes ou 
genuinamente hostis à democracia como forma de governo - segundo a pesquisa do Latinobarômetro $2002^{13}$, apenas $56 \%$ dos entrevistados suportam a democracia de forma integral na região (Canache e Allison, 2003). A mesma pesquisa em 2009 aponta para 59\% de suporte, um leve incremento, porém ainda abaixo do pico histórico da série iniciada em 1995 que foi de $63 \%$ em $1997^{14}$. Almeida constatou em suas pesquisas que

o brasileiro confia muito pouco no próximo e tem uma enorme confiança na família (13\% confiam ou confiam muito na maioria das pessoas, $34 \%$ nos amigos, $88 \%$ na família). (...) Salta a evidência que o brasileiro não se preocupa, ou não dá importância ao associativismo político. O reflexo é tão danoso na consolidação quanto na construção da identidade de agremiações políticas (Almeida, 2006-b, p. 48).

Bignotto vê a corrupção como um risco para os fundamentos da democracia, a partir de uma ampliação dos horizontes da análise. Segundo o autor,

é possível concluir que no Brasil, se a corrupção é em grande medida o efeito do comportamento ilegal de funcionários públicos, ela é um fenômeno que atinge setores muito mais amplos da nossa sociedade e ameaça romper o equilíbrio constitucional atentando contra alguns de seus princípios fundamentais (Bignotto, 2006, p. 85).

O autor defende que esse conceito mais alargado está mais próximo das preocupações dos cidadãos comuns, e ajuda a ver que a corrupção é um risco para os fundamentos da democracia.

Já os estudos de Norris parecem apontar para um menor risco de descrença em valores democráticos. A autora desenvolveu um esquema conceitual distinguindo os diferentes níveis ou objetos do suporte político em cinco dimensões: a comunidade política, os princípios do regime, a performance do regime, as instituições do regime e os atores políticos. Em suas pesquisas globais, a autora, embora confirme a queda da confiança política como um todo, conclui que a crença nos valores do regime democrático em si estaria se preservando. A deterioração do suporte se projeta mais sobre o desempenho das instituições, sobre a comunidade política e os atores políticos (Norris, 1999). Conforme conclui a autora, embora tenham se tornado céticos em relação à democracia, os cidadãos dos estados sob democracias novas em consolidação

\footnotetext{
${ }^{13}$ Latinobarómetro é um estudo de opinião pública sobre questões políticas e sociais que aplica anualmente cerca de 19 mil entrevistas em 18 países de América Latina, representando mais de 400 milhões de habitantes.

${ }^{14} \mathrm{http}: / / \mathrm{www}$.latinobarometro.org, acessado em 01 de dezembro de 2010.
} 
preferem esses novos regimes aos autoritarismos que os antecederam, ainda que essas democracias continuem infestadas por conflitos étnicos, polarização religiosa, corrupção administrativa generalizada, intimidação e desonestidade eleitoral, desigualdades socioeconômicas severas, controle sobre a imprensa, coerção a movimentos de oposição, legislaturas fracas, sistema partidário altamente fragmentado ou com predominância de um só partido, crime organizado violento em ascensão, e uso arrogante do poder executivo contra instituições (Norris, 1999). A autora defende que as tendências de queda da confiança política do cidadão nas instituições do regime são passíveis de uma interpretação mais positiva, que venha a fortalecer governos democráticos. Trata-se do crescimento de cidadãos mais críticos, insatisfeitos com as autoridades estabelecidas e instituições hierárquicas tradicionais, que sentem que os canais de participação existentes estão aquém dos ideais democráticos e que queiram melhorar e reformar os mecanismos institucionais da democracia representativa (Norris, 1999). Nessa linha de pensamento, Mishler e Rose argumentam que "um ceticismo saudável facilita a sociedade democrática mais do que uma confiança cega" (Mishler e Rose, 2001, p. 41).

No Brasil, a crise de confiança nas instituições do regime democrático e nos atores políticos parece bastante aguda. Os cidadãos, de uma maneira geral, têm uma visão extremamente negativa dos políticos. Almeida apurou em sua pesquisa que $50 \%$ do eleitorado brasileiro acredita que todos os políticos roubam (Almeida, 2006-b). Segundo dados da World Value Survey 1995-1997, 58,9\% dos entrevistados no Brasil acreditam que todos os agentes públicos se engajam em corrupção, e outros $23,5 \%$ acreditam que a maioria o faz (Canache e Allison, 2003).

Norris aponta efeitos adicionais desse crescente cinismo, uma vez que isso poderia acarretar menor engajamento político e evitar entre as elites a entrada dos melhores e mais brilhantes no serviço público (1999). Segundo Filgueiras,

do mesmo modo que as instituições democráticas sofrem os efeitos da corrupção, a elite política e partidária não possui prestígio diante do eleitorado. (...) Como a democracia é um método para instituir uma elite política, sua relação com a corrupção circunscreve-se na baixa participação política. Ademais, ocorre uma fragmentação do sistema partidário, ao se dividirem as elites políticas (Filgueiras, 2008-b, p. 161). 
Em outras palavras, a falta de prestígio das lideranças políticas reduz a participação dos cidadãos na democracia responsável por instituir essas mesmas lideranças.

\subsubsection{Igualdade política e desigualdades sociais}

Outro efeito da corrupção sobre a democracia de que trata a literatura, o terceiro na lista de Filgueiras (2008-b), é a ampliação das desigualdades sociais. Esse efeito tem correlação com a dimensão da igualdade na qualidade da democracia. Ainda que essa tenha sido pensada mais em termos de igualdade política, Dietrich Rueschemeyer ressalta que as estruturas da igualdade social e econômica são entrelaçadas com a igualdade política (2005). Os ideais democráticos de Dahl sugerem um ponto de contato entre igualdade e responsividade, ao demandarem "a responsividade contínua do governo à preferência dos seus cidadãos, considerados como iguais políticos" (Dahl, 1977, p. 25).

Rueschemeyer aponta que

há muito mais em jogo do que o papel do dinheiro em campanhas eleitorais. Os ricos têm uma grande influência em todas as fases de criação e implementação de políticas mesmo quando a corrupção direta está sob controle efetivo, o que obviamente não é o caso em muitos países (2005, p. 55, tradução nossa).

Filgueiras diz que

a corrupção tem efeitos distributivos em função da relação entre o Estado e o setor privado. Sistemas de suborno e pagamentos de propina criam assimetrias mercadológicas, o que prejudica a democracia no sentido da alocação dos recursos públicos. A fatia maior dos ganhos é acumulada pelos vencedores nos esquemas de 
corrupção, deixando a base social com uma fatia menor (2008-b, p. 161).

Pode-se acrescentar que isso também prejudica a democracia na medida em que torna desiguais as oportunidades de intervenção sobre o processo político e o Estado por parte da maioria dos cidadãos, que não possuem grande poder econômico e não participam dos esquemas de corrupção. Campos sugere a existência de um mecanismo de concentração semelhante, ao comentar que

para o setor privado, a inserção no espectro político por meio de contribuições pecuniárias pode levar a ganhos de oportunidades cujo efeito possível seria a própria distorção da livre competitividade de mercado, dado o grau de influência prévia de determinados indivíduos ou de grupos sociais. Nesse sentido, haveria uma clara desigualdade política, que poderia ser traduzida em benefícios concentrados para uns e custos difusos para os demais (Campos, 2009, p. 21).

Analisando os altos custos das campanhas eleitorais e suas formas de financiamento, David Samuels conclui que "a análise das fontes de fundos de campanha no Brasil nos dá bases empíricas para afirmar que os interesses das elites empresariais influenciam as eleições e o processo político" (Samuels, 2006, p. 139). O autor aponta para o fato de que

embora historicamente o poder se tenha concentrado nas mãos de poucos no Brasil, a competição democrática oferece a possibilidade popular nas políticas de governo. No entanto, o sistema brasileiro de financiamento fora de controle das campanhas (para todos os efeitos) tende a perpetuar o status quo, por apertar ainda mais os laços entre as elites políticas conservadoras e os interesses empresariais, e limitar a capacidade de interesses novos terem voz nas instituições de representação brasileiras (Samuels, 2006, p. 152).

Embora Samuels especifique as elites políticas conservadoras, parece que tal comentário é válido e se aplica mesmo no caso de elites políticas ditas progressistas. Além disso, pode-se provavelmente dizer de qualquer elite que é conservadora de si mesma, independentemente de seu posicionamento ideológico frente à sociedade.

Como conclui Filgueiras, "a corrupção, do ponto de vista econômico, tem efeitos nocivos à democracia, porquanto consolida um sistema desigual de alocação dos recursos públicos" (Filgueiras, 2008-b, p. 161). Analisando-se o conjunto de autores estudados, pode-se supor um mecanismo que se auto alimenta, operando da seguinte 
forma: a desigualdade sócio-econômica implica em desigualdade política. Essa representação desproporcional, amplificada pela corrupção política, favorece as elites estabelecidas, aumentando a concentração de riquezas através da sua influência nos mecanismos distributivos do Estado, levando ao aprofundamento das desigualdades sociais.

\subsubsection{Competição e centralização do poder político}

O quarto efeito da corrupção política sobre a democracia listado por Filgueiras é "a centralização excessiva pela criação de uma elite política que se reproduz no poder" (2008-b, p. 159). O autor elabora que

a corrupção contribui para uma centralização excessiva do poder, ao possibilitar a hegemonia de uma elite política, que se arraiga no comando pela manipulação do acesso político como retorno para outros ganhos econômicos. Em outras palavras, a corrupção contribui para reproduzir uma elite política que se encastela no poder, controlando as oportunidades econômicas em função da baixa competição, tendo em vista o domínio sobre o acesso a cargos públicos e impedimento da abertura substancial da política (Filgueiras, 2008-b, p. 162).

Por essa elaboração, se aclara que esse efeito tem impacto direto sobre a competição, enquanto dimensão da qualidade democrática.

Filgueiras aponta a baixa competição como engrenagem do mecanismo que levaria à hegemonia de uma elite política encastelada no poder. Pelo menos no caso do Brasil, outros autores tem um entendimento distinto, de que há uma intensa competição. Segundo Samuels, “campanhas caras sinalizam competição política intensa” (2006, p. 148). Ainda assim, esse autor acredita que a importância óbvia do dinheiro para o sucesso eleitoral tem muito mais implicações negativas do que positivas para a 
democracia no Brasil. Samuels corrobora com a ideia do fenômeno da hegemonia sugerido por Filgueiras, ao comentar como a concentração histórica de poder nas mãos de poucos tende a ser perpetuada pelo sistema brasileiro de campanha fora de controle (2006). Talvez a conciliação entre esses pensamentos esteja na visão de Bruno Speck, que aponta para a distorção da competição eleitoral a partir da distribuição dos recursos pelos seguintes motivos:

[1] o poder econômico dos candidatos que se auto-financiam, [2] o abuso de recursos do Estado para financiar unilateralmente candidatos ou partidos governistas, e [3] o acesso desigual ao financiamento privado (Speck, 2006, p. 154).

Segundo Almeida,

a melhor explicação para a variação de recursos disponíveis - na qual a minoria tem muito e a maioria tem pouco - está no casamento entre a política e a máquina pública. Sobram evidências de que, quanto maior a inserção do partido nos postos das administrações, maior a capacidade de levantar recursos privados e públicos (Almeida, 2006-b, p. 84).

Em outras palavras, haveria no Brasil uma intensa competição política, evidenciada pelos grandes volumes gastos nas campanhas eleitorais. Essa competição sofreria, entretanto, a distorção de somas desproporcionais de dinheiro gastas em campanhas pelas elites políticas dominantes, que levantariam tais recursos através da prática da corrupção política no exercício do poder público. O fato de os atores detentores do poder político serem incentivados por essa intensa competição a praticar a corrupção política afeta, como se viu, a qualidade da democracia.

Alguns autores sugerem que a efetiva alternância de poder é a melhor prova da existência de uma competição saudável no campo político-eleitoral. Diamond e Morlino argumentam que "ao se provar impossível substituir o partido regente através de eleições, o sistema fica aquém do limite de democracia, em alguma forma de regime autoritário eleitoral", (Diamond e Morlino, 2005, p. xviii, tradução nossa). Entretanto, o fato de um partido ganhar várias eleições não deveria representar necessariamente um problema, desde que o faça mediante um ambiente competitivo em que não existam entraves para os desafiantes. Por isso a importância de se investigar o processo competitivo, não apenas o resultado, na avaliação da competição enquanto dimensão da 
qualidade da democracia. De todo modo, em 2002 o Brasil cumpriu o rito de alternância de poder com a eleição para presidente de Luiz Inácio Lula da Silva do principal partido de oposição, o PT, com posicionamento mais à esquerda no espectro ideológico e grande identificação popular. Ainda assim, ao final do seu primeiro mandato, autores como Samuels apontavam para a tendência de perpetuação do status quo pelo contínuo estreitamento dos laços entre as elites políticas e os interesses empresariais, em consequência do financiamento de campanha fora de controle no país (Samuels, 2006). Essa constatação leva a pensar que os mesmos interesses empresariais que já recebiam especial atenção dos governos anteriores continuavam sendo privilegiados pelo governo Lula. Assim sendo, apesar da renovação das elites políticas, não teria ocorrido, portanto, uma efetiva alternância de poder entre diferentes extratos da sociedade. Até que ponto, sendo possível substituir o partido regente, mas não as elites financeiras que financiam tanto incumbentes quanto desafiantes, tal sistema alcança ser uma democracia e não alguma forma de regime autoritário eleitoral? Essa questão se apresenta como uma extrapolação do raciocínio de Diamond e Morlino, apresentado acima, para o nível das elites financeiras financiadoras das elites políticas, e embora não seja objeto desta dissertação, será abordada no próximo capítulo. 


\section{Capítulo 3}

\section{Os custos das campanhas eleitorais e o comportamento do eleitor na construção dos incentivos à corrupção política no Brasil}

Esse capítulo aborda os níveis de corrupção política e os custos das campanhas eleitorais no Brasil. Através da discussão sobre o peso do dinheiro nas eleições e da tolerância do eleitorado aos sinais de corrupção, pretende-se explorar como esses fatores incentivam os atores políticos à prática da corrupção política, bem como investigar a eficácia do accountability vertical em combatê-la, tendo por base debates correntes na literatura.

Um dos elos fundamentais que conecta a corrupção política às falhas $o$ accountability eleitoral em combatê-la é o alto custo das campanhas. À medida que o dinheiro tem grande importância nas eleições e sendo necessárias grandes somas para que candidatos e partidos tenham chances de vitória nos pleitos, a prática da corrupção política distorce a competição em favor dos corruptos, impactando a eficácia do accountability vertical na de punição dos que a praticam e que assim prejudicam a responsividade dos governos às preferências da maioria dos cidadãos. 


\subsection{Níveis de corrupção política no Brasil}

Conforme discutido no capítulo anterior, a corrupção política é fenômeno de difícil mensuração, e os principais esforços são no sentido de medir sua percepção, obtida por pesquisa de opinião. De acordo com o índice CPI (Corruption Perception Index) da organização Transparência Internacional ${ }^{15}$, em 2010 o Brasil ocupava a $69^{\text {a }}$ posição entre os 178 países avaliados naquela edição, com um CPI de 3,7 em uma escala que vai de 0 (altamente corrupto) a 10 (muito limpo), estável em comparação com o ano anterior, conforme critérios daquele estudo. Os países no topo do ranking são Dinamarca, Nova Zelândia e Singapura com CPI 9,3, e os piores colocados são Iraque, Afeganistão, Myanmar e Somália, todos com índices de 1,5 para baixo. Na mesma faixa que o Brasil encontram-se Itália e Geórgia logo acima e Cuba, Montenegro e Romênia logo abaixo. Outros países que merecem destaque pela relevância comparativa com o Brasil são os Estados Unidos com CPI 7,1 em $22^{\circ}$ lugar, China em $78^{\circ}$ com 3,5, México em $98^{\circ}$ com 3,1 , Argentina em $105^{\circ}$ com 2,9, Rússia em $154^{\circ}$ com 2,1, e Venezuela em $164^{\circ} \operatorname{com} 2,0$.

A percepção da corrupção no Brasil conforme medida pelo CPI parece estar em linha com as observações descritivas de autores da Ciência Política sobre os níveis de corrupção em nosso país. Citando Matthew Taylor, José Álvaro Moisés chama atenção para o fato de que

a corrupção permeia (...) todas as esferas da vida pública brasileira, caracterizando um quadro relativamente fora de controle, ou seja, de natureza endêmica, em relação ao qual, o sistema político não foi ainda capaz de desenvolver anticorpos institucionais eficazes (Moisés, 2008-c, p. 19).

Fernando Filgueiras afirma que

a corrupção se tornou um tipo de prática cotidiana à política, em especial em sua dimensão representativa, na qual a falta de

\footnotetext{
${ }^{15}$ http://www.transparency.org/policy_research/surveys_indices/cpi/2010, acessado em 20 de dezembro de 2010 .
} 
responsividade implica o fato de sua desocultação criar uma endemia das delinquências do homem público (2008. p. 167).

O efeito "contagioso" da prática da corrupção é ressaltado por Heloísa Starling ao analisar o conto secular, porém atualíssimo de Machado de Assis, a Serena República, observando que

o efeito da corrupção política acentua as condições de adesão da maioria ao argumento, na aparência, irrefutável, de que parece tolice obedecer às regras quando se espera que os demais venham a desobedecê-las e quando um, porventura, deixa escapar uma chance de obter algum tipo de vantagem ou benefício pessoal nessa sociedade, ainda que trapaceando suas normas, passa por otário (Starling, 2008, p. 268).

Rogério Arantes diagnostica que

a corrupção no Brasil é amplamente espalhada entre diversos setores da administração pública e instituições políticas. (...) A fotografia da corrupção no Brasil que as operações da Polícia Federal analisadas pintam é aterrorizante (Arantes, no prelo, p. 35, tradução nossa).

O autor chegou a essa conclusão após avaliar 600 operações da Polícia Federal entre 2003 e 2008 , e observar que

22,7\% das operações da Polícia Federal tinham por alvo corrupção política. (...) Se somarmos todos os casos em que corrupção foi o crime principal ou secundário, corrupção sobe de $22,7 \%$ para $38,8 \%$ das operações da Polícia Federal (Arantes, no prelo, p. 25, tradução nossa). 


\subsection{A (in)eficácia do accountability vertical como instrumento de punição dos políticos corruptos}

Tomando-se a responsividade como dimensão central da qualidade democrática e considerando-se o impacto da corrupção política sobre ela conforme discutido nos capítulos anteriores, somos levados, conforme já foi discutido, a avaliar a eficácia do accountability vertical no combate à corrupção política. Isso requer a definição de parâmetros para se examinar tal eficácia. Proponho neste estudo o conceito de eficácia do accountability vertical no combate à corrupção política como sendo a rejeição por parte expressiva do eleitorado dos candidatos ou partidos que tenham praticado a corrupção política durante o período entre pleitos, reduzindo assim suas chances de manutenção ou expansão do poder político nas corridas eleitorais. Em outras palavras, o accountability vertical funciona no combate à corrupção política quando os eleitores punem os atores políticos que a praticam, negando-lhes o voto e não os reelegendo. É importante ressaltar que a decisão pela premiação ou punição de um ator político pelo eleitor no momento de decidir seu voto leva em consideração a performance do político de forma abrangente. Embora se esteja estudando o accountability vertical no que tange à corrupção, há muito mais em jogo no processo de aprovar ou rejeitar um candidato.

Para que um eleitor possa decidir pela punição dos corruptos, algumas condições precisam ser satisfeitas, a saber:

1. O eleitor precisa ter alguma informação de que o candidato praticou atos de corrupção enquanto exercia mandato em cargo eletivo, na condição de ator político durante o período entre pleitos;

2. O eleitor precisa ver nisso um problema prioritário em relação a outros critérios, algo ruim a ser evitado. Precisa sentir-se lesado ou traído pelo político candidato em função do ato de corrupção;

3. É necessário que o eleitor enxergue alternativas válidas e aceitáveis, sentindo-se capaz de identificar os candidatos que são corruptos e aqueles que não o são. Para poder punir um candidato ou partido, o eleitor tem 
que acreditar minimamente em uma diferenciação entre candidatos mais e menos corruptos e saber apontá-la para poder punir um dando seu voto para outro.

A primeira dessas condições, a de acesso à informação, depende, conforme discutido na introdução, do bom funcionamento do accountability horizontal, através do qual órgãos de controle, o parlamento e a oposição monitoram os atores políticos no poder e denunciam as irregularidades. Nesse processo, é fundamental o papel exercido pela imprensa, que tem que ser livre, acessível aos diversos pontos de vista políticos e ativa em publicizá-los, a fim de fortalecer tanto o accountability horizontal quanto o vertical, uma vez que a imprensa exerce o papel de facilitador da conexão entre os dois, à medida que informa aos eleitores o que apuram os órgãos de controle, o parlamento e a oposição. No Brasil, dada o alto volume de denúncias de corrupção na mídia tanto impressa quanto televisiva, pode-se dizer que o acesso à informação está funcionando. A imprensa tem bom trânsito junto aos órgãos de fiscalização e à justiça, e graças às garantias de proteção da fonte tem conseguido apresentar à sociedade dados e fatos oriundos de investigação policial ou processo judicial, incluindo escutas telefônicas e imagens de vídeo, que compõem evidências suficientes para permitir que essa condição seja cumprida a contento. As notícias de corrupção chegam a grande parte dos eleitores, pelo menos em casos que ganham maior notoriedade.

A segunda condição, a de que o eleitor dê importância prioritária para o fato da corrupção, não vem sendo satisfeita na mesma proporção. Moisés comenta que embora seja insuficiente a pesquisa sobre a relação entre as percepções e as atitudes dos cidadãos a respeito da corrupção e suas consequências para o funcionamento da democracia, e ainda que estudos mais recentes, além de não apresentarem resultados conclusivos, raramente tenham tratado diretamente da relação dos eleitores com a corrupção, e das consequências dessa relação para a qualidade da democracia, a reação do eleitorado brasileiro às evidências de corrupção tem gerado considerável preocupação quanto à eficácia do accountability vertical como instrumento de preservação e melhoria da qualidade da democracia (Moisés, 2008-c). Os sinais de permissividade à corrupção dados pelo eleitorado brasileiro têm um forte efeito negativo sobre os incentivos que os atores políticos têm para tomar suas decisões durante o período entre eleições. 
Moisés vê sinais dessa permissividade ao constatar que, apesar do governo de Luis Inácio Lula da Silva ter sido atingido, em meados de 2005, por uma grave crise política provocada por escândalos de corrupção envolvendo o seu esquema de apoio parlamentar, o seu partido político e os seus mais importantes ministros,

Lula reelegeu-se, em 2006, com mais de $60 \%$ dos votos dos eleitores, o que sugere que embora o voto seja o instrumento mais direto de responsabilização de governantes à disposição dos cidadãos, a maioria dos eleitores brasileiros ainda não relaciona o uso indevido de recursos públicos para fins privados com os déficits de qualidade da democracia no país, ou, mais grave, não atribui importância a isso (Moisés, 2008-c, p. 1).

O fato de as preferências expressas nas eleições não colocarem a honestidade como desejo prioritário da maioria da população não implica dizer que há aqui falta de responsividade, nem que accountability vertical não funciona, apenas que ele não é eficaz no combate à corrupção. A responsividade e o accountability vertical se dão em relação a uma cesta de preferências, e o eleitor pode privilegiar outros critérios que não a corrupção ${ }^{16}$. Conforme coloca Luis Felipe Miguel,

A multifuncionalidade da representação implica múltiplas prestações de conta; o eleitor deve não apenas ser capaz de acompanhá-las - na medida de seu interesse - como dar a cada uma seu justo peso no momento de produzir uma avaliação global do desempenho do governante (Miguel, 2005, p. 29).

As pesquisas de Alberto Almeida entre 1998 e 2002 indicam que a corrupção só foi considerada o maior problema do Brasil, em média, para 2\% dos eleitores (Almeida, 2008). Em pesquisas anteriores, reproduzidas na tabela 1 (Alberto, 2006-b, p. 43), o autor apurou que $49 \%$ do eleitorado brasileiro acha que político honesto não tem sucesso na política; $41 \%$ acha que é melhor resolver rapidamente um problema da população, mesmo que para isso seja preciso pagar por fora; $39 \%$ acha que político que faz muito e rouba um pouco merece o voto da população; $39 \%$ acha que político muito honesto não sabe governar; e 33\% acha que não faz diferença se um político rouba ou não, o importante é que ele faça as coisas que a população precisa (Almeida, 2006-b).

\footnotetext{
${ }^{16}$ Não está no escopo desta dissertação o estudo de outros critérios de responsividade que não aqueles relacionados à corrupção.
} 
Tabela 1

O apoio social ao clientelismo

\begin{tabular}{|c|c|c|c|}
\hline \multicolumn{2}{|c|}{$\begin{array}{c}\text { Atitudes que famílias pobres passando fome } \\
\text { DEVERIAM ter, se um candidato oferecesse uma } \\
\text { cesta básica }\end{array}$} & \multicolumn{2}{|c|}{$\begin{array}{l}\text { Atitudes que famílias DEVERIAM, ter se um } \\
\text { candidato oferecesse caminhão de tijolos para } \\
\text { terminar a construção de suas casas }\end{array}$} \\
\hline Aceitar cesta básica e votar no candidato & $50 \%$ & $\begin{array}{l}\text { Aceitar caminhão de tijolos e votar no } \\
\text { candidato }\end{array}$ & $48 \%$ \\
\hline $\begin{array}{c}\text { Não aceitar cesta básica e votar em outro } \\
\text { candidato }\end{array}$ & $50 \%$ & $\begin{array}{l}\text { Não aceitar caminhão de tijolos e votar em } \\
\text { outro candidato }\end{array}$ & $52 \%$ \\
\hline \multicolumn{2}{|c|}{$\begin{array}{c}\text { Atitude que mãe que não consegue vaga para } \\
\text { colocar filho na escola DEVERIA ter, se um } \\
\text { candidato oferecesse uma vaga }\end{array}$} & \multicolumn{2}{|c|}{$\begin{array}{l}\text { Atitude que grupo de amigos DEVERIA ter, se um } \\
\text { candidato oferecesse reformar campo de futebol }\end{array}$} \\
\hline Aceitar a vaga e votar no candidato & $55 \%$ & Aceitar a reforma e votar no candidato & $41 \%$ \\
\hline $\begin{array}{c}\text { Não aceitar a vaga e votar em outro } \\
\text { candidato }\end{array}$ & $45 \%$ & $\begin{array}{l}\text { Não aceitar a reforma e votar em outro } \\
\text { candidato }\end{array}$ & $59 \%$ \\
\hline \multicolumn{2}{|c|}{$\begin{array}{c}\text { Atitude que mãe com um filho doente DEVERIA } \\
\text { ter, se um candidato oferecesse dinheiro para } \\
\text { tratamento médico }\end{array}$} & \multicolumn{2}{|c|}{$\begin{array}{l}\text { Atitude que pais DEVERIAM ter, se um candidato } \\
\text { oferecesse uma bicicleta para a criança }\end{array}$} \\
\hline Aceitar o dinheiro e votar no candidato & $64 \%$ & Aceitar a bicicleta e votar no candidato & $32 \%$ \\
\hline $\begin{array}{l}\text { Não aceitar o dinheiro e votar em outro } \\
\text { candidato }\end{array}$ & $36 \%$ & $\begin{array}{l}\text { Não aceitar a bicicleta e votar em outro } \\
\text { candidato }\end{array}$ & $68 \%$ \\
\hline
\end{tabular}

Fonte: Almeida, 2006-b.

Esses resultados levaram Almeida a concluir que "há uma enorme tolerância com a utilização privada do que é público, desde que isso ocorra, na perspectiva solidária, para melhorar a situação do próximo" (2006-b, p. 46).

O quadro acima sugere também que não vem sendo atendida a terceira e última condição listada neste estudo para a eficácia do accountability vertical no combate à corrupção política, que é a crença do eleitorado em alternativas à corrupção. Moisés alerta que

acreditar que todos os líderes políticos são corruptos ou de que a corrupção se justifica porque muitos políticos a praticam (...) não ajuda a democracia a melhorar a sua qualidade, porque as opções eleitorais orientadas por essa posição, ao serem apresentadas à sociedade, simplesmente supõem que a possibilidade de mudança política não existe (Moisés, 2008-c, p. 3).

De forma semelhante, Damarys Canache e Michael Allison afirmam que

se os cidadãos simplesmente acreditam que todos os políticos são corruptos, isso seria um mau presságio para o destino da democracia, já que nenhuma das alternativas eleitorais teriam apelo para o eleitor (Canache \& Allison, 2003, p. 92-93, tradução nossa). 
Desse modo, observa-se que no Brasil o eleitor tem, em geral, acesso às informações sobre a corrupção política e seus atores. Entretanto, parece não ligar esses fatos ao preterimento de suas próprias preferências em favor das preferências dos financiadores da classe política, ou não dá muita importância a isso. Diante disso e da percepção de que não há alternativas viáveis disponíveis, desenvolve uma tolerância à corrupção que impacta a eficácia do accountability vertical na melhoria da qualidade da democracia através da redução da corrupção política ${ }^{17}$, redução essa que possibilitaria maior responsividade dos governos às preferências da maioria dos cidadãos em lugar das preferências dos financiadores da classe política. Isso torna os eleitores mais suscetíveis aos investimentos massivos em marketing político, aumentando a pressão da demanda por recursos financeiros sobre os atores políticos na posição de candidatos.

\subsection{Decisão do voto e marketing político}

O processo pelo qual o eleitor decide o seu voto é subjetivo e complexo. André Singer defende a influência de fatores de longo prazo como ideologia e afinidade partidária (Singer, 2000), enquanto Yan Carreirão sugere que o papel da ideologia na decisão do voto abrange mais possibilidades do que apenas a ideia de identificação através do autoposicionamento esquerda-direita (2007). Almeida acredita que a ideologia influencia o voto. Porém, ela não é determinante para eleger um presidente. A ideologia condiciona o ponto de partida dos candidatos (2006-b), mas "face à influência de fatores conjunturais, ela deixa de ser importante no momento da escolha do candidato" (Almeida, 2007). Há um certo consenso de que esse processo sofre a influência de fatores de curto prazo como o desempenho da economia. Se é, por um lado, um processo de escolhas racionais, sofre também influências culturais e nota-se

\footnotetext{
${ }^{17}$ O jornal O Estado de São Paulo publicou em 08 de agosto de 2010 matéria listando 25 então candidatos a diferentes cargos envolvidos em 17 escândalos de corrupção. Conforme tabela apresentada em detalhes no apêndice 1, 15 desses candidatos tiveram votação suficiente para se elegerem, ainda que algumas candidaturas tenham sido indeferidas. 2 candidatos desistiram e apenas 8 não obtiveram votos suficientes.
} 
uma carga emocional ao levar em consideração empatia e aparência física de um candidato $^{18}$. Há um caloroso debate na literatura quanto ao papel da imagem de um candidato ou partido no processo de tomada de decisão do voto. Alguns autores consideram que o voto pela imagem é uma decisão emocional, em contraposição ao que seria uma decisão racional, baseada em fatos e análises iluministas, mais desejável para a democracia. Eles sustentam ainda que o marketing político tira o foco das campanhas políticas de questões substantivas, propriamente pertencentes à esfera política. Outros autores entendem que a escolha pela imagem é na verdade uma decisão racional que reflete uma estratégia de redução dos custos de tomada de decisão, utilizada principalmente pelos eleitores de mais baixa capacidade cognitiva, menos acesso à informação ou menor interesse por política. Citando estudos da psicologia política americana, Jairo Pimentel Junior observa que "segundo uma boa parcela dessa literatura, as emoções se entrelaçam com a razão e precisam ser levadas em consideração, se quisermos entender como os eleitores pensam e decidem o voto" (Pimentel Jr., 2007, p. 116).

Afora isso, há outros fatores a considerar no caso de cargos legislativos em eleições proporcionais, poucos eleitores têm informação sobre o quão complexo é o sistema de agregação de votos e distribuição de cadeiras entre os partidos concorrentes. Nicolau intui que "há uma percepção por parte dos eleitores de que são eleitos os candidatos que obtêm mais votos, à maneira de um sistema majoritário que elege mais de um representante" (Nicolau, 2002, p. 224). O autor acredita que os eleitores não entendem o processo de distribuição de cadeiras entre as coligações de acordo com o percentual de votos de cada uma, e só então é considerada a votação individual de cada candidato para definir, dentro de uma coligação, quem ocupará as cadeiras que lhe cabem $^{19}$.

\footnotetext{
${ }^{18}$ A iniciativa da então pré-candidata à presidência da república pelo PT em 2010, Dilma Rousseff, em submeter-se a uma cirurgia plástica e em 2002 as alterações no corte de barba e estilo dos ternos do então candidato Lula servem de indício confirmatório da importância dada ao atributo da aparência física.

${ }^{19}$ A expressiva votação do candidato Tiririca para deputado federal em 2010, foi interpretada como um voto de protesto ou de deboche. Tomando-se isso como verdade é muito provável que esses mais de 1 milhão de eleitores não tivessem a consciência de que ao fazê-lo estariam ajudando a eleger outros três candidatos da coligação, Otoniel Lima (PRB), Vanderlei Siraque (PT) e o delegado Protógenes Queiroz (PCdoB). Pior, mesmo depois das eleições, provavelmente continuam sem sabê-lo. Cf.

http://eleicoes.uol.com.br/2010/ultimas-noticias/2010/10/05/partido-de-tiririca-quase-dobra-bancada-nacamara-dos-deputados.jhtm, acessado em 08 de Janeiro.
} 
Também o número elevado de candidatos nas eleições proporcionais aumenta em demasia o custo da escolha baseada em levantamento de informações, e pode acabar levando à não-decisão (Rennó, 2006). O fato de que 33,3\% dos eleitores anularam o voto ou votaram em branco para deputado federal na média das eleições de 1986, 1990, 1994 e 1998 (Nicolau, 2002) pode ser evidência desse fenômeno. É fato que em 2006 esse percentual de brancos e nulos caiu para 11,5\% para deputado federal, sendo de 19,5\% para senador, contra 8,5\% para presidente. Em 2010, brancos e nulos ficaram praticamente estáveis em 11,8\% para deputado federal e subiram para 23,4\% para senador, contra $8,6 \%$ para presidente no $1^{\circ}$ turno ${ }^{20}$.

Segundo Lucio Rennó, há certos requisitos informacionais mínimos, sem qualquer um dos quais o processo de accountability vertical, de prestação de contas entre eleito e eleitor se vê drasticamente afetado: é imperativo que os eleitores saibam reconhecer e identificar seus representantes (nome e número); o eleitor deve ter alguma informação sobre o desempenho dos seus representantes no exercício do mandato; e devem poder diferenciar os candidatos à reeleição daqueles que disputam uma vaga sem estar exercendo mandato (Rennó, 2006).

Desse modo, memorizar em quem se votou, seja partido ou candidato, é essencial para se fiscalizar o político, ou não se pode cobrar o cumprimento de promessas (Almeida, 2006-a). Além disso, se o eleitor não sabe se o candidato em quem votou foi eleito ou não, a possibilidade de punição dos representantes é impraticável (Rennó, 2006). Preocupa, portanto o resultado de pesquisa coordenada por Almeida, realizada em 2002, segundo a qual $30 \%$ dos eleitores não se lembravam em quem tinham votado para deputado federal apenas dois meses após as eleições daquele ano, e $78 \%$ não se lembravam em quem tinham votado quatro anos antes, em 1998 (Almeida, 2006-a).

Ainda que seja difícil ou impossível entender o processo de decisão do voto em sua totalidade, e mesmo que a mensuração efetiva dos fatores isolados seja por vezes impraticável, é possível identificar a influência de alguns fatores isolados, e é válido considerar que tais fatores atuam no comportamento do eleitor, sabendo-se que o peso relativo dessas influências varia de um pleito a outro. Dentre esses fatores, destaca-se a imagem que o eleitor faz de um candidato ou partido, imagem essa cuja formação e

\footnotetext{
${ }^{20}$ http://www.tse.gov.br, acessado em 19 de dezembro de 2010.
} 
manipulação são a razão de ser do marketing político nas campanhas eleitorais, demandando grandes somas financeiras em sua formulação estratégica e execução. "É sabido que o peso do dinheiro nas eleições não é desprezível, o que tende a concentrar o sucesso eleitoral nas mãos de partidos (ou candidatos) com maior acesso a recursos financeiros" (Campos, 2009,p. 16).

A crescente profissionalização do marketing político ou eleitoral, conforme apontada por Silvia Cervellini (2000), é uma das formas pela qual o dinheiro gasto em campanha influencia o processo eleitoral, à medida que os melhores e mais talentosos profissionais e agências de propaganda são atraídos pelas perspectivas de ganho financeiro e de prestígio profissional que essa atividade proporciona. Outra expressão está no surgimento e proliferação de cursos de aperfeiçoamento e pós-graduação em Marketing Político.

A maior parte dos recursos financeiros de uma campanha política é empregada no processo de convencimento do eleitor através do marketing político, que vai muito além do convencimento racional pelo entendimento e alinhamento às preferências dos eleitores, focando-se mais em forjar percepções, criar empatia, explorar o medo, a esperança ou outros fatores emocionais e subconscientes e conquistar pela insistência e repetição. Todas práticas comuns do marketing comercial, onde embora já não se tolere a propaganda mentirosa ou enganosa explícita, fica claro que a sociedade ainda permite e aceita como ética a propaganda fantasiosa de alegações subjetivas, cada vez mais utilizada no marketing político. De acordo com Jerry Palmer, é comum a analogia entre marketing de produtos e marketing político. Os elementos principais em ambos são a competição, o produto, os canais de comunicação e a persuasão. Em ambos, vale a regra básica: "know the product, know the competition, understand the audience" (Palmer, 2002, p. 351). Seguindo o mesmo raciocínio, Cervellini (2000) enumera os pontos de convergência entre marketing político e de produtos: 1) semelhança no foco da ação: o indivíduo; 2) semelhança na função social: regular/organizar a competição; 3) semelhança no fim da ação: influir/determinar uma escolha; 4) semelhanças no ambiente da ação: opiniões, crenças e valores. Renato Janine Ribeiro oferece uma explicação para a suscetibilidade do eleitor ao marketing político em um paralelo com a suscetibilidade do consumidor ao marketing comercial: 
os eleitores não vêm a formular o seu voto de maneira iluminista, pelo exame das diferentes propostas, e sim movidos pelo afeto (...), o que é legítimo, porque o que se decide no voto são essencialmente valores (...), o problema está no sequestro do afeto pela mídia, inflacionando os custos das campanhas mesmo quando a propaganda é gratuita" (Ribeiro, 2006, p. 79).

Diante de tais semelhanças, abrimos parênteses para apontar que é possível se supor um aspecto positivo da profissionalização desse marketing para a responsividade dos governos à preferência da maioria dos cidadãos, que é a prática de entender os desejos e anseios do consumidor, aplicada ao eleitor. Grandes investimentos em dinheiro e tecnologia são feitos para entender o eleitor em seu processo de decisão do voto (Cervellini, 2000). Embora o objetivo seja mais que nada saber o que ele quer ouvir, para então convencê-lo por um candidato ou partido, esse investimento contribui para prover o ator político com um entendimento mais abrangente e preciso das preferências políticas do eleitorado em diversas questões públicas, tanto em relação ao posicionamento ideológico quanto em questões de ordem prática. Ainda que mais pesquisa seja necessária para confirmar o benefício de tal prática, algumas evidências impressionistas levam a crer que esse conhecimento termina por influenciar a formação de políticas públicas, operando um mecanismo que pode ser considerado de viés democrático, ainda que de tendência plebiscitária, trazendo para a democracia representativa instrumentos típicos da democracia participativa direta ${ }^{21}$.

\footnotetext{
${ }^{21}$ Dois exemplos recentes foram a discussão em torno do pedágio urbano nas eleições municipais de São Paulo em 2008 e o debate sobre a legalização do aborto na eleição presidencial de 2010. Em ambos os casos, os candidatos tiveram que adotar publicamente posições aparentemente contrárias às suas preferências pessoais, em função da rejeição que essas ideias sofreram pelo eleitorado, conforme evidenciado em pesquisas de opinião contratadas pelos candidatos àquelas eleições.
} 


\section{4. $O$ alto custo das campanhas eleitorais e peso do dinheiro nas eleições}

Um dos elos fundamentais que conecta a corrupção política às falhas do accountability eleitoral é o alto custo das campanhas. Segundo David Samuels "a sabedoria popular diz que o dinheiro conta muito em política" (2006, p. 133). À medida que custa caro manter-se no poder político ou expandi-lo, candidatos e partidos estão motivados a praticar a corrupção política com vistas a levantar fundos de campanha que os tornem competitivos. Nesse sentido, a existência de eleições tem um efeito colateral inverso ao pretendido, uma vez que, como já foi discutido, a corrupção política impacta a qualidade da democracia. Torna-se relevante para o tema proposto, portanto, investigar quão caras são as campanhas no Brasil, e que fatores afetam seus custos.

Samuels aponta que as eleições brasileiras são extremamente caras em perspectiva comparada (2006), ainda mais levando-se em conta que no Brasil os números oficiais subestimam o valor real de uma campanha. Apenas os custos declarados já seriam por si só mais altos que em outros países, sendo as eleições presidenciais no Brasil quase tão caras quanto as norte-americanas (Samuels, 2006), pelo menos aquelas anteriores à eleição do Presidente Barack Obama em 2008. Mauro Campos observa que

o dinheiro representa cada vez mais um importante ingrediente para o sucesso eleitoral, e os partidos, assim como os candidatos, necessitam, a cada campanha, de mais dinheiro, a fim de obterem sucesso em suas disputas eleitorais (2009, p. 16).

O gráfico 1 a seguir apresenta essa realidade de custos crescentes ao apresentar as despesas totais somadas de todos os candidatos conforme declaração obrigatória por lei feita ao Tribunal Superior Eleitoral. Os dados de 2002, 2004, 2006 e 2008 foram obtidos junto ao site asclaras organizado pela ONG Transparência Brasil ${ }^{22}$. O montante de 2010 foi obtido em notícia divulgada pelo TSE em seu site ${ }^{23}$.

\footnotetext{
${ }^{22}$ http://www.asclaras.org.br, consultado em 30/12/2010.

${ }^{23}$ http://www.tse.gov.br, consultado em 30/12/2010.
} 
Gráfico 1

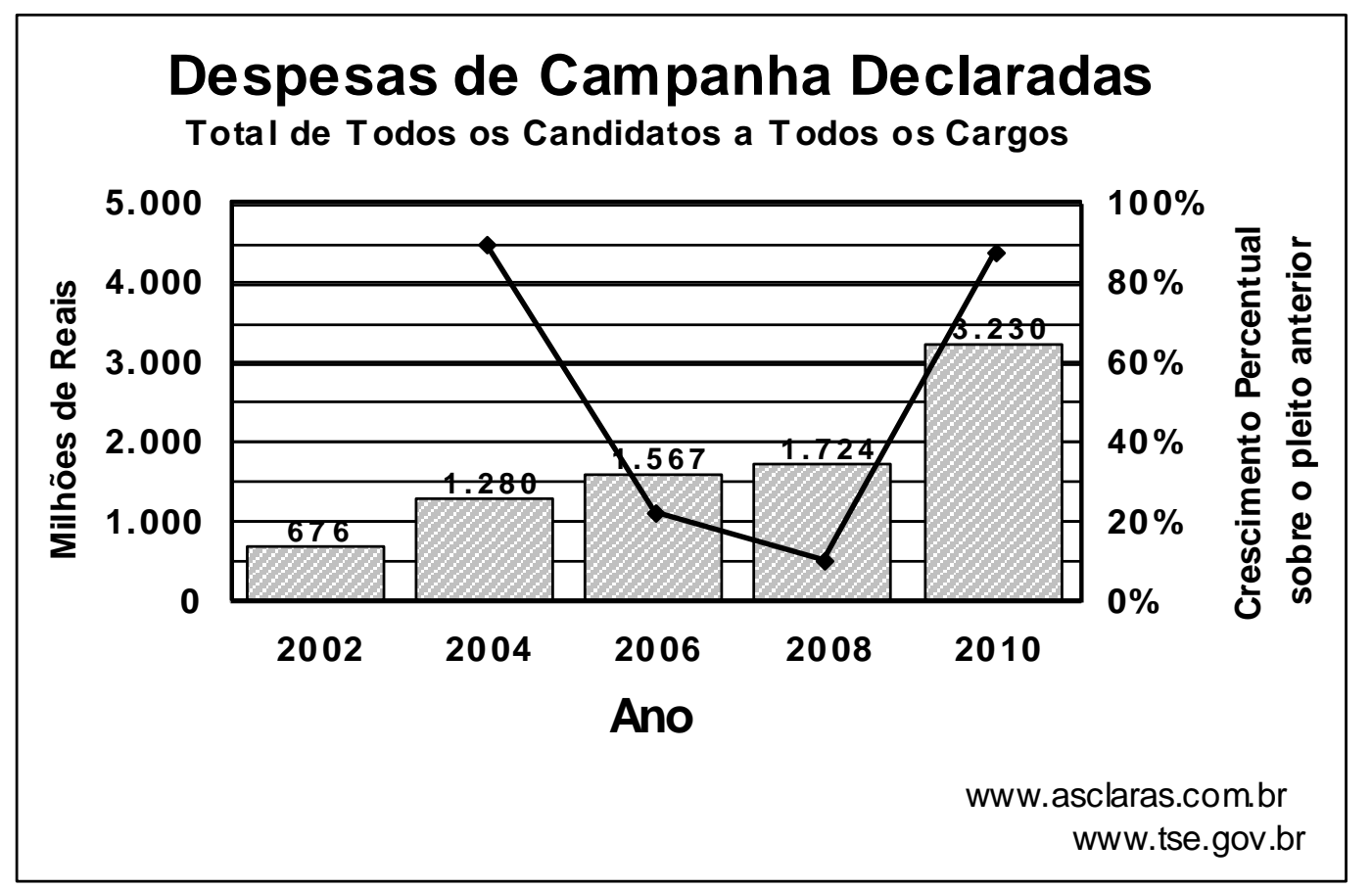

Algumas estratégias de financiamento de campanha adotadas por candidatos e comitês podem acarretar distorções nos valores totais obtidos junto ao TSE. Trata-se das transferências de fundos entre comitês financeiros de campanha e candidatos, e vice versa. Essas transferências aparecem como despesas para quem transfere e como doações para quem recebe, tendendo a inflar os números. Isso exigiria uma investigação mais detalhada, o que não é, entretanto, objetivo deste estudo. De todo modo, pode-se depreender que as despesas com as campanhas eleitorais no Brasil vem mais ou menos dobrando a cada quatro anos entre 2002 e 2010. É importante destacar, entretanto, as possíveis distorções de uma análise temporal feita apenas sobre os valores das receitas e despesas declaradas à Justiça Eleitoral. Isso porque um aumento nas doações "por dentro" podem representar uma migração das doações feitas em Caixa 2 em pleitos anteriores, sem que isso represente um aumento efetivo nas doações totais. Em sua maioria, as despesas, pela característica visível dos produtos e serviços que pretendem custear, são mais facilmente declaráveis ${ }^{24}$. Conforme observa Campos,

não nos convém pensar (de forma ingênua) que nas eleições passadas as campanhas eram mais baratas, que o setor privado financiava menos ou, mesmo, que se gastava menos com o custeio do sistema partidário-eleitoral. Dito isso, pode-se pensar em outra possibilidade, a

\footnotetext{
${ }^{24}$ Conforme discutido em detalhes no próximo capítulo, seção 4.6.
} 
partir dos dois formatos de doações privadas: partidárias e eleitorais. Da mesma forma que as doações efetuadas diretamente aos partidos, fora do período eleitoral, aumentaram de forma expressiva, os valores privados doados nos períodos eleitorais tiveram incrementos substanciais. Ora, se se tem uma elevação nesses dois formatos, o incremento poderia ser então consequência de uma maior transparência na declaração dos financiamentos obtidos para as campanhas eleitorais (Campos, 2009, p. 133).

Ainda que o senso comum aponte para um aumento expressivo nos custos das campanhas eleitorais, essa observação se faz importante para que não se tome os dados oficiais do TSE como evidência satisfatória dessa intuição.

Wendy Hunter também afirma que o Brasil é um país onde as campanhas eleitorais estão entre as mais caras do mundo, onde o dinheiro influencia muito a possibilidade de sucesso, e onde o financiamento de campanha sofre pouca regulação legal efetiva. Segundo a autora, isso privilegia o relacionamento entre as elites políticas conservadoras e os interesses da classe empresarial (Hunter, 2007). Pode-se observar que esse relacionamento se dá também com as elites políticas ditas progressistas, como a própria autora leva a concluir no desenvolvimento do seu estudo sobre o comportamento fisiológico do Partido dos Trabalhadores a partir de 1995.

A literatura aponta para algumas razões para os altos custos das campanhas eleitorais no Brasil. Entre os fatores que favorecem o alto custo das campanhas eleitorais e por consequência o grande peso do dinheiro no resultado das eleições no Brasil está a utilização de listas abertas, no caso de eleições proporcionais. Os candidatos a cargos proporcionais - vereadores, deputados estaduais e deputados federais - têm que se diferenciar individualmente, levantando e gastando fundos para construir uma base de voto personalizado por meio de favores, presentes e outros benefícios (Samuels, 2006), já que a lista aberta tende a estimular as campanhas centradas no candidato, que buscam então reforçar seus atributos (reputação pessoal) para distinguir-se de seus colegas ou dos atributos comuns a todo o partido (reputação partidária) (Nicolau, 2002). 
Pesquisa do IUPERJ (IUPERJ-2002, apud Nicolau, 2007) apontou que, para 92\% dos eleitores, o candidato foi mais importante que o partido na escolha do voto para deputado federal $^{25}$, conforme quadro a seguir:

Tabela 2

Na escolha para deputado federal, o que foi mais importante, o candidato ou o partido ao qual ele pertence?

\begin{tabular}{|l|c|c|c|c|c|}
\hline & \%Candidato & \% Partido & \% Os dois & \% Total & \% Total da Coluna \\
\hline PFL & 96 & 2 & 2 & 100 & 4 \\
\hline PMDB & 86 & 8 & 6 & 100 & 8 \\
\hline PSDB & 87 & 7 & 6 & 100 & 10 \\
\hline PT & 83 & 7 & 10 & 100 & 25 \\
\hline Outros & 91 & 6 & 3 & 100 & 7 \\
\hline Não sabe/não respondeu & 98 & 1 & 1 & 100 & 46 \\
\hline Total & 92 & 4 & 4 & 100 & 100 \\
\hline
\end{tabular}

Fonte: Pesquisa IUPERJ-2002

Nota: $\mathrm{n}=1,394$; chi-quadrado: 79.275 ; sig. $(0,00)$ : phi: 0,238 ; sig. $<0,001$

Analisando as amostragens das eleições de 1994, 1998 e 2002, Jairo Nicolau (2007) constatou que o número de deputados federais que não se reelegeram por terem sido derrotados por outros candidatos da lista aberta do mesmo partido ou coligação é mais que o dobro dos que não se reelegeram por causa do desempenho do partido. Esses fatos podem ser interpretados como forte indício de intensa disputa entre os candidatos de um mesmo partido. Essa disputa encarece as eleições, porque os políticos não possuem ferramentas baratas para que sua mensagem chegue aos eleitores, das quais a mais óbvia seria o apelo partidário, baseado em programas e plataformas coletivas (Samuels, 2006).

Outro problema apontado no uso das listas abertas é a possibilidade de coligação entre os partidos, o que reduz a previsibilidade dos resultados eleitorais, tornando mais difícil que o eleitor premie ou puna um candidato pela sua performance, já que candidatos podem aumentar sua votação e não se reelegerem, enquanto outros podem obter um número menor de votos e mesmo assim garantir a sua reeleição (Nicolau, 2002). Campos salienta que

tais incertezas sobre os resultados eleitorais também povoam a cabeça dos atores políticos e podem conduzi-los a adoção de medidas que possibilitem maximizar suas chances de acesso aos cargos eletivos. Uma das formas de acesso é a maior disponibilidade de recursos para

\footnotetext{
${ }^{25}$ Pesquisa IUPERJ-2002, apud NICOLAU (2007), p. 109-110
} 
serem gastos nas disputas eleitorais, o que pode induzir o ator político a estabelecer compromissos durante as campanhas (Campos, 2009, p. $16)^{26}$.

A necessidade de recursos financeiros expressivos pode levar a uma relação de dependência entre atores políticos, candidatos e partidos de um lado e grupos econômicos fortes do outro. Em pesquisa realizada pela Revista Época em 2009, 64,3\% dos congressistas entrevistados acredita ser baixa ou muito baixa a chance de um cidadão comum ser eleito para a Câmara dos Deputados sem o apoio de grupos econômicos corporativos ou religiosos, e 86,1\% acham baixas ou muito baixas as mesmas chances no caso do Senado Federal (Clemente, Loyola, Ramos \& Mendonça, 2009). Essa barreira financeira de entrada no poder político pode estar por trás do diagnóstico de Helio Jaguaribe de que "temos mais gente corrupta que se elege do que eleitos que se corrompem" 27 .

Dimitri Vlassis, chefe da Seção de Corrupção e Crimes Econômicos do Escritório das Nações Unidas sobre Drogas e Crime (UNODC), declarou, fazendo um alerta sobre as eleições presidenciais no Brasil, então por vir, que "financiamento de campanha é um problema chave em muitos países. Quanto mais alto o custo, maior o risco (de corrupção) ${ }^{, 28}$.

Outro fator que contribui para a prática da corrupção política é a ineficácia da justiça como fator inibidor conforme explicitada por Taylor, para quem

o desempenho da Justiça Eleitoral deixa muito a desejar, avançando pouco no sentido de fiscalizar a participação dos partidos ou dos candidatos nas mesmas eleições, e muito menos ainda na punição de eventuais erros decorrentes da atuação desses atores políticos (Taylor, 2006, p. 149).

O autor faz tal afirmação a partir de um raciocínio baseado no sistema eleitoral, que incentiva um número imenso de candidaturas e partidos e infla os custos e a agressividade das campanhas, inclusive pela competição entre correligionários. Além do consequente aumento do universo a ser regulado e fiscalizado pela Justiça Eleitoral, a

\footnotetext{
${ }^{26}$ Adicionalmente aos fatores discutidos acima, o próximo capítulo apresenta uma discussão sobre o impacto do horário gratuito do programa eleitoral nos gastos de campanha ao gerar uma demanda por produção midiática de alto custo.

${ }^{27}$ Em entrevista ao jornal O Estado de São Paulo, publicada em 08 de março de 2009.

${ }^{28}$ Em entrevista ao jornal O Estado de São Paulo, veiculada em 20 de março de 2010.
} 
separação desta das demais instituições judiciárias dificulta o monitoramento, a fiscalização e a punição efetivos. Taylor adiciona que esse quadro é de difícil solução, dado que mudanças na legislação eleitoral estão justamente nas mãos daqueles que mais se beneficiam de uma legislação pouco rigorosa.

Essa perspectiva de impunidade se alia à percepção de tolerância do eleitor às notícias de corrupção (já discutida neste capítulo) e à demanda por recursos financeiros para sustentar as campanhas, formando um poderoso mecanismo de incentivos sobre o ator político na direção da prática da corrupção política. Essa demanda decorre da importância crescente que o marketing político assume na competitividade e eficácia das campanhas eleitorais e dos altos custos envolvidos na sua elaboração e execução. Conforme observa Campos,

nas democracias modernas, os programas eleitorais assumem, cada vez mais, um caráter complexo e caro, com o uso de recursos televisivos sofisticados e com elevado grau de profissionalização, dado pelo marketing eleitoral ${ }^{29}$. Assim, por representarem um valor expressivo, os custos com divulgação de partidos e de candidatos podem se constituir num diferencial nas competições eleitorais. Desse modo, os gastos com publicidade e mídia se tornam um dos principais atributos das competições eleitorais, podendo ter um impacto efetivo nas escolhas dos eleitores (Campos, 2009, p. 61-62).

\subsection{Competição entre elites políticas e competição entre seus financiadores}

Conforme já foi discutido, é importante para a qualidade da democracia que haja um certo nível de competição entre as elites políticas, uma vez que a competição é apontada por Larry Diamond e Leonardo Morlino como motor da democracia (2005). Tal analogia se justifica por ser essa uma dimensão que além de servir de sintoma atua

\footnotetext{
${ }^{29} \mathrm{Na}$ literatura em geral, o uso de "marketing político", adotado por esta dissertação, se sobrepõe com larga vantagem à expressão "marketing eleitoral" utilizada pelo autor nesta frase. Ainda que se possa atribuir uma distinção entre esses termos, a diferença é irrelevante para este estudo.
} 
como remédio. Quanto maior a competição e a participação - o outro motor apontado pelos autores - mais avança a qualidade da democracia nessas e em outras dimensões. Essa importância já era identificada por Robert Dahl, que adota essas dimensões na construção do conceito de poliarquia (Dahl, 1977).

Pelo que se pode observar, há evidências de uma desejável competição entre lideranças políticas distintas pelo acesso ao poder político, entre as quais o emprego de grandes somas nas campanhas eleitorais. Por outro lado, as observações analisadas neste estudo levam a supor uma razoável dependência das elites políticas para com as elites econômicas que parecem financiar as campanhas de ambos os lados. Isso leva a um questionamento adicional quanto à qualidade da democracia na dimensão da competição: até que ponto essas lideranças representam interesses distintos, ou servem ao mesmo mestre? Uma competição que acrescentasse qualidade à democracia deveria ser entre diferentes alternativas, cada qual lutando na arena política de forma democrática pela consideração dos seus interesses e preferências.

A análise da competição pela ótica dos interesses não aparece bem trabalhada na literatura política aqui analisada. Ainda que sem elaborar uma construção teórica que suporte esse raciocínio, por não ser objetivo dessa dissertação, pode-se sugerir um caminho empírico, embora não trilhado neste estudo, para investigar a competição pelo lado dos representados, e não apenas dos representantes, em linha com a relevância dada ao financiamento por Campos. Segundo o autor, "não há como analisar a construção de um processo democrático sem levar em consideração os recursos financeiros que sustentam essa edificação" (Campos, 2009, p. 16). Ele acrescenta que "o financiamento da política mantém uma relação direta com a representação política" (Campos, 2009, p. 16-17). Esse caminho seria a análise das doações de campanha, no que tange às suas fontes e origens. Na opinião de Samuels, no Brasil, o mercado de financiamento de campanha é dominado por poucos atores. $\mathrm{O}$ autor complementa que

empresas contribuem muito mais que indivíduos, e a maior parte dos contribuintes empresariais vem (não à toa) de setores grandemente influenciados por regulamentação governamental, ou muito dependentes de contratos públicos: bancos, setor financeiro, indústria pesada, construção civil (Samuels, 2006, p. 134). 
Mesmo que o financiamento de campanha seja oriundo primordialmente de empresas, e de um número reduzido delas, concentradas em uns poucos setores da atividade econômica, ainda assim pode haver competição, embora segmentos da sociedade se vejam alienados da mesma. Basta, para isso, que se conceba alguma forma hipotética de alinhamento exclusivo entre grupos de interesses e lideranças políticas, grupos esses formados seja por identificação regional, por atividade econômica, composição societária ou outra característica agregadora de interesses e preferências. Por exemplo, agronegócio versus indústria, exportadores versus importadores, sul versus norte, bancos versus indústrias de capital intensivo ou empresários locais versus multinacionais. A competição entre os financiadores fica prejudicada, entretanto, se a relação entre grupos de interesse e lideranças políticas é difusa, o que se dá quando empresas contribuem com as campanhas de várias lideranças, muitas vezes na proporção de suas chances de sucesso apontadas pelas pesquisas de intenção de voto, e à medida que várias empresas, supostamente pertencentes a grupos de interesse distintos, contribuem para uma mesma liderança política. É natural que as empresas adotem esse tipo de comportamento, uma vez que essas lideranças representam uma cesta de políticas, e os interesses empresariais de diversos setores da economia precisam ver-se representados nelas, ainda que tenham cada um suas predileções e divergências; uma cesta de propostas políticas oferecidas em um programa partidário necessariamente contemplará o agronegócio e a indústria, o norte e o sul, e assim por diante.

Até onde foi possível investigar, a literatura recente da Ciência Política brasileira não se aprofundou nesse aspecto empírico das contribuições de campanha dedicado a analisar a competição entre os financiadores de campanha, o que pode ser uma sugestão para futuros estudos do tema. 


\subsection{Reformas política e eleitoral}

Tem se verificado nos últimos anos uma acalorada discussão sobre reformas políticas no meio político e em toda a sociedade civil. Campos observa que "os movimentos recentes pró-reforma política ganharam força com a crise do 'Mensalão' no governo Lula" (Campos, 2009, p. 120). O movimento da "ficha limpa", que resultou na promulgação da lei complementar 135/2010, pode ser considerado uma dessas expressões da sociedade, ainda que caibam questionamentos de o quão amplo foi o envolvimento popular, principalmente se observada a votação expressiva que alguns candidatos ditos "ficha suja" tiveram no pleito de 2010, conforme descrito no apêndice $1 .^{30}$

Como consequência, muitos cientistas políticos têm se dedicado ao assunto. Algumas das observações e recomendações encontradas na literatura sobre o tema e o objeto desta dissertação encontram-se relacionadas a seguir.

Embora não seja objetivo discutir alternativas ou sugerir soluções para os problemas estudados, faz-se relevante abordar as reformas quando o assunto é corrupção, Caixa 2 de campanha e sua relação através da eficácia do accountability vertical. Segundo Speck,

o objetivo da diminuição da importância do dinheiro na política coincide com o ideal de uma relação mais orgânica e consciente entre os partidos políticos e o seu eleitorado. A mera influência do dinheiro é vista como uma influência maléfica sobre o processo eleitoral (Speck, 2006, p. 154).

Como aponta Newton Bignotto,

quando se discute reforma política no Brasil, um dos obstáculos mais citados para o pleno desenvolvimento da vida democrática no país é a corrupção frequente dos agentes do Estado e os prejuízos causados

\footnotetext{
${ }^{30} \mathrm{O}$ movimento "ficha limpa" não fez parte do escopo deste estudo, uma vez que a aplicabilidade da lei 135/2010 dele decorrente já nas eleições de 2010 seguiu sendo questionada mesmo após a diplomação dos eleitos, e uma vez que seus efeitos ainda não são devidamente conhecidos e passívies de estudo.
} 
pelo que muitos acreditam ser um fato generalizado na vida pública (Bignotto, 2006, p. 82).

Samuels conclui que "o sistema atual faz muito pouco para desencorajar o uso do Caixa 2, mas reformas políticas viáveis poderiam ser usadas para reduzir a corrupção no financiamento de campanha" (Samuels, 2006, p. 152).

Almeida alerta para o fato de que são complexas e delicadas as alterações institucionais que almejam uma maior eficácia do accountability vertical, com menor peso do dinheiro nas eleições e assim menor incentivo à prática de corrupção política por aqueles que pretendem manter o poder político através de sucessivas eleições. A proibição das contribuições de campanha por empresas privadas, por exemplo, poderia ter um efeito negativo à medida que estimularia o Caixa 2 de campanha e das empresas (Almeida, 2006-b).

Rennó questiona a sugestão corrente no meio político de proibir as coligações nas eleições proporcionais, chamando a atenção para o fato de que se não for acompanhada de medidas para a diminuição do número de candidatos que cada partido pode apresentar, poderia ter um efeito negativo na capacidade do eleitor de aprender sobre os candidatos, uma vez que coligações, na verdade, contribuem no sentido de reduzir o número total de candidatos que competem nas eleições (Rennó, 2006).

Ribeiro chama a atenção para a conexão percebida entre corrupção política e financiamento de campanha, ao comentar que "na literatura especializada, a discussão do financiamento de campanha é uma espécie de finale de análises ou relatos mais longos sobre a corrupção" (Ribeiro, 2006, p. 78).

Segundo Eduardo Posada-Carbó,

é necessária uma reavaliação apropriada da democracia representativa, de modo a reconhecer a centralidade dos partidos e do processo eleitoral. (...) Apenas apreciando o seu papel central nas democracias, poderemos aceitar subsequente significância chave dos problemas de partidos e financiamento de campanha (Posada-Carbó, 2008, p. 23, tradução nossa).

Entretanto, como afirma Lúcio Rennó, toda mudança institucional traz embutidos custos não antecipados pelos reformadores - fatores esses, muitas vezes perversos, e 
quanto mais complexa a proposta de engenharia institucional, mais difícil se faz prever as consequências da reforma (Rennó, 2006).

As reformas decididas na canetada e sob a luz de cismas e escândalos podem complicar um pouco mais o quadro político e evidenciar o dito de que, "por pior que esteja a situação, ela sempre pode piorar" (Campos, 2009, p. 212).

Speck alerta que a discussão em torno da regulação do sistema político e sua reforma está fortemente vinculada aos

valores que devem ser fortalecidos por essa reforma: a garantia de uma competição eleitoral mais equilibrada, a independência entre financiadores e doadores, ou o fortalecimento da equidade cidadã no financiamento das campanhas. Mesmo que esses objetivos não sejam mutuamente excludentes, as ferramentas a serem escolhidas para enfrentar cada um desses desafios variam bastante (Speck, 2006,, p. $155)$.

Ribeiro considera que

o problema da reforma política brasileira é de que poucos assuntos, nela, assumem vulto e são considerados, pela opinião pública, como relevantes. (...) O debate da reforma política brasileira é pouco político, porque confinado a especialistas e porque apartado das divisões partidárias (Ribeiro, 2006, p. 77).

É pouco político porque o povo não o toma como seu, delegando-o a especialistas, e porque não retrata um recorte entre posições políticas.

Posada-Carbó destaca a importância da participação política para que as reformas se dêem na direção desejada.

Sem a pressão da opinião pública [e a participação da sociedade], as regras democráticas ou se mantém intocadas pelos políticos, ou são alteradas da forma mais benéfica para os próprios políticos. Em 1896 (...) o Professor J. W. Jenks alertou que "nenhum homem entende melhor os motivos que guiam os homens na vida diária do que $o$ politico; e nenhum homem usa esse conhecimento para atingir seus próprios propósitos de forma mais habilidosa do que ele". Qualquer tentativa de entender e reformar o papel do dinheiro na política deve ter esse alerta em mente. (Posada-Carbó, 2008, p. 27, tradução nossa). 
Esse capítulo tratou, entre outras coisas, da distorção da competição eleitoral pelo investimento da propina oriunda de corrupção política em marketing político. Uma vez que essa propina é dinheiro ilegal e, portanto, não declarado, sua injeção nas campanhas eleitorais tende a se fazer por meio de Caixa 2. Assim sendo, a fim de aprofundar a investigação e permitir um melhor entendimento sobre esses fenômenos, faz-se necessária uma discussão sobre o Caixa 2 no financiamento de campanha, apresentada no próximo capítulo desta dissertação. 


\section{Capítulo 4}

\section{O Caixa 2 no financiamento de campanhas eleitorais}

Esta dissertação adota a definição de Bruno Speck de financiamento de campanhas eleitorais, segundo a qual ela envolve "os recursos materiais empregados pelos competidores em eleições populares (partidos e candidatos) para organizar a campanha e convencer os cidadãos a lhes conferirem o voto" (2006, p. 153). Não são considerados financiamento de campanha, portanto, os recursos empregados no financiamento ordinário das organizações partidárias ou a remuneração dos representantes eleitos. $\mathrm{O}$ autor ressalta que

apesar de que os recursos financeiros tendem a se tornar a moeda mais frequente no apoio material a campanhas eleitorais, outras formas de apoio material são bastante comuns. Empresas colocam veículos à disposição dos candidatos, fornecem camisetas e outros bens. Prestadores de serviços ajudam com descontos em pesquisas, anúncios ou outros recursos valiosos em campanhas (Speck, 2006, p. 154).

Cabe ressaltar a diferença desse conceito para o mais abrangente financiamento político, definido por Campos (2009) como o fluxo de recursos, públicos e privados, que visa financiar todo o funcionamento do sistema político-partidário, incluídos aí não apenas os gastos de campanha, mas também o custeio das estruturas partidárias em períodos entre eleições e o custo da máquina pública responsável pela condução e supervisão do processo eleitoral em si. Desse modo, o financiamento de campanhas é uma parte do financiamento político, conforme as definições acima. 


\subsection{O financiamento público de campanha e o horário gratuito para propaganda eleitoral}

O foco dessa dissertação é o financiamento privado de campanhas. Cabem, contudo, algumas considerações sobre o financiamento público, composto pela renúncia fiscal aos partidos, pelo fundo partidário e principalmente pelo Horário Gratuito para Propaganda Eleitoral - HGPE. Esse último, embora não incorra em custos para os partidos e candidatos, o que lhe vale a classificação de gratuito, custa aos cofres públicos na forma de renúncia fiscal, pela isenção de Imposto de Renda concedida às emissoras de radiodifusão que são obrigadas a transmitir o HGPE. Tal componente não é desprezível, como observa Campos,

a monetarização do benefício público da mídia eletrônica como financiamento público indireto aponta para uma participação expressiva do Estado no custeio do sistema partidário-eleitoral, da mesma forma que reforça a presença dos partidos como atores importantes no processo eleitoral (Campos, 2009, p. 22).

O autor aponta que essa mídia, se monetarizada, representou algo em torno de $71 \%$ do custo financeiro do sistema partidário-eleitoral no ano de 2006, "seguido de longe pelo financiamento privado (declarado) para as eleições, que representa um volume próximo de 20\%" (Campos, 2009, p. 209). Um rápido cálculo aponta que o financiamento privado não declarado teria que ser 2,5 vezes maior que o declarado ( $R \$$ 2,50 em Caixa 2 para cada $\mathrm{R} \$ 1,00$ declarado) para que o financiamento privado se equiparasse monetariamente ao financiamento público sob a forma de HGPE.

À primeira vista, a expressividade do financiamento público de campanhas poderia induzir a se pensar em uma certa equidade distributiva de recursos, a favor de uma competição eleitoral mais equilibrada. Um olhar mais atento, entretanto, sugere pelo menos três fatores que atuam na direção contrária, acentuando a concentração de poder e reduzindo a competição, ou tornando-a menos equilibrada e justa. $\mathrm{O}$ primeiro são os critérios para a distribuição do tempo gratuito de televisão entre os partidos. Pela legislação eleitoral, conforme a lei no .9 .504 de 30 de setembro de 1997, 1/3 do espaço é 
dividido em frações iguais entre todos os partidos que tenham representação na Câmara dos Deputados e candidatos no pleito corrente - o que representa muito pouco por partido, dado o grande número de partidos. Os $2 / 3$ restantes são distribuídos de forma proporcional à composição da Câmara no início do período legislativo. Tal distribuição é, portanto, conservadora, privilegiando aqueles que estejam mais presentes no poder, em detrimento de partidos entrantes ou menores, protegendo assim os incumbentes e desequilibrando a competição. Segundo Speck, "a vinculação de um dos mais importantes recursos na eleição ao sucesso eleitoral no passado tende a perpetuar a relação de forças entre os partidos" (2006, p. 157).

O segundo são os critérios internos de cada partido para alocação desse tempo entre os diferentes candidatos. Segundo Campos, o HGPE

é um recurso caro, essencial e exclusivo dos partidos políticos e tão estratégico que sequer é mencionada a forma de distribuição interna desse recurso nos estatutos partidários. Esse fato remete a decisões $a d$ hoc por parte das lideranças partidárias (Campos, 2009, p. 208).

Como já foi discutido, no caso de cargos legislativos muito da competição eleitoral se dá dentro dos próprios partidos, em função do sistema eleitoral de lista aberta. Assim sendo essa competição interna aos partidos fica até certo ponto cerceada, uma vez que os candidatos ficam à mercê da vontade dos dirigentes partidários, favorecendo a concentração de poder nas mãos dos mesmos.

O terceiro fator relacionado ao HGPE que pode levar a uma maior distorção na competição enquanto dimensão da qualidade da democracia é a consequente demanda por recursos financeiros consideráveis para fazer frente aos altos custos de produção midiática investidos na geração de conteúdo que possa ocupar esse tempo de forma eficaz e competitiva. Esse fenômeno carece, todavia, de pesquisa que permita confirmação empírica. Analistas como Speck (2003) consideram que os custos referentes à produção de programas eleitorais para emissoras de rádio e de televisão podem alcançar o montante de $\mathrm{R} \$ 20$ milhões para um candidato de uma campanha para eleições presidenciais no Brasil. Esse valor representaria mais de $50 \%$ das contribuições privadas declaradas por cada um dos dois principais candidatos à presidência nas eleições de 2002, à época da 
estimativa do autor ${ }^{31}$. Segundo Torquato Jardim, “O acesso gratuito ao rádio e à televisão para propaganda eleitoral (...) tornou-se um ônus pesado; os custos de produção são exorbitantes - cerca de $70 \%$ do total das principais campanhas" (2004, sp.). Essa demanda por investimentos é apontada por alguns autores como pressão causadora da corrupção. Moisés elabora o argumento de que

o uso da televisão em campanhas eleitorais exigiria o investimento de recursos somente mobilizáveis pela promessa de favores a financiadores privados. Isso teria levado os partidos a recorrer aos chamados 'gastos eleitorais não contabilizados', ou seja, ao uso de recursos privados fora da lei em campanhas eleitorais, como foram classificados a partir da experiência do “mensalão" em 2005 no Brasil (Moisés, 2010, p. 30).

O que o autor chama de "recursos privados fora da lei" encaixa-se na definição de Caixa 2 de campanha adotada neste estudo.

Não faz parte do escopo deste estudo avaliar de forma abrangente e compreensiva a contribuição do HGPE à qualidade da democracia no Brasil, mas apenas ressaltar o potencial nocivo de uma de suas facetas, uma vez que, conforme discutido no capítulo anterior, a demanda por recursos financeiros na competição eleitoral é um dos motores do mecanismo de incentivos à prática da corrupção política atuando sobre os atores políticos.

\footnotetext{
${ }^{31}$ A campanha de Lula declarou gastos de R \$ 39 milhões, enquanto a de Serra R \$ 35 milhões nas eleições presidenciais de 2002.
} 


\subsection{O financiamento privado e o Caixa 2 de campanha}

Estabelecida a relevância do financiamento público de campanhas, cabe justificar a escolha pelo foco no financiamento privado, seguido por esta dissertação. Tal justificativa está enraizada no tema deste estudo, uma vez que se pretende avaliar a relação das doações para o financiamento de campanha com a corrupção política. Conforme já foi argumentado, o conceito de corrupção adotado pressupõe o envolvimento de uma entidade privada como beneficiária do uso indevido dos recursos públicos. Assim sendo, é na doação privada ao financiamento de campanha que se pode encontrar indícios do impacto da corrupção política sobre o accountability vertical operado pelas eleições no Brasil. E, em particular, naquela feita sob a forma de Caixa 2, cuja natureza oculta casa bem com a ilicitude da corrupção política. Conforme observa Speck, "o problema do financiamento privado de campanha se mescla fortemente com a questão do abuso da máquina governamental para fins eleitorais” (2006, p. 155).

Conforme descrito no primeiro capítulo, esta dissertação trabalha com o conceito de Caixa 2 de campanha definido como as doações com fins ao financiamento privado de campanhas eleitorais cuja origem verdadeira não seja declarada à justiça eleitoral. Mais uma vez, a especificidade de "origem verdadeira" visa classificar de Caixa 2 de campanha aquelas doações "esquentadas" por doadores "laranjas", que assumem a autoria de doações feitas por terceiros que não querem se identificar. Ainda que esse componente adicione dificuldade a qualquer esforço de mensuração, há indícios de que deixá-lo de fora dessa classificação seria uma omissão quantitativamente representativa. Além disso, a informação quanto às fontes verdadeira das contribuições de uma campanha é de grande relevância, conforme ressalta Speck ao afirmar que

o financiamento de campanha é parte integral e essencial das propostas políticas que estão sendo apresentadas pelos partidos e candidatos. Para que os cidadãos possam fazer uma escolha baseada em informações, é necessário que saibam antes das eleições os principais dados sobre o financiamento (Speck, 2006, p. 158). 
Desse modo, pela definição aqui adotada, é a origem das contribuições e não os gastos que define o financiamento de campanha através de Caixa 2, sempre que sua origem seja não declarada ou seja declarada de forma fraudulenta.

Definido o conceito, essa dissertação busca confirmar a existência e relevância do Caixa 2 nas doações de campanha no Brasil, bem como descrever mecanismos pelos quais tal fenômeno opera e investigar agências e incentivos a que estão submetidos os atores tanto políticos quanto privados que o praticam.

Nas palavras de Walter de Almeida Guilherme, presidente do Tribunal Regional Eleitoral - TRE de São Paulo empossado em 2010, "Caixa 2 é geral no Brasil, não só na eleição" ${ }^{32}$. Guilherme voltou a afirmar na abertura do $49 .^{\circ}$ Encontro do Colégio dos Presidentes de TREs em São Paulo, em junho do mesmo ano, referindo-se aos gastos de campanha, que "o Caixa 2 existe generalizadamente e sou descrente quanto a dizer que ele será banido" ${ }^{33}$. Embora o reconheça como um dos aspectos mais nefastos do processo eleitoral no Brasil, o presidente do TRE-SP não acredita ser possível eliminá-lo do processo eleitoral, sendo obrigação da justiça eleitoral "minimizar o quanto for possível, reduzir o dano". Essa opinião é corroborada pela vice-procuradora-geral eleitoral da república, Sandra Curreau, a cargo da supervisão das eleições presidenciais, que declarou ser quase impossível a missão de buscar rastros de dinheiro de origem ilícita no pleito ${ }^{34}$.

Em discurso na Assembléia Legislativa do Paraná em abril de 2010, em meio ao escândalo dos diários secretos do legislativo daquele estado, o deputado estadual Jocelito Canto (PTB) perguntou em plenário "Quem é que não tem Caixa 2 na campanha?" e declarou: "O Caixa 2 é invisível. Ganha eleição. É mais forte que os recursos oficiais recebidos. Quem é que paga essas equipes de 50 pessoas que viajam pelo estado?"35. Jocelito foi reeleito em 2006 como o $12^{\circ}$ deputado mais votado, com 65.284 votos, tendo declarado receitas de $\mathrm{R} \$ 126$ mil naquela campanha. Estimando-se de forma conservadora o custo mensal de um cabo eleitoral, incluindo remuneração e despesas de viagem, entre $\mathrm{R} \$ 2$ e 3 mil, as 50 pessoas referidas pelo deputado teriam representado um

\footnotetext{
${ }^{32}$ Em entrevista ao jornal O Estado de São Paulo, publicada em 14 de fevereiro de 2010.

${ }^{33}$ Reportagem publicada no Jornal O Estado de São Paulo, em 11 de junho de 2010.

${ }^{34}$ Em entrevista ao jornal O Estado de São Paulo, publicada em 04 de julho de 2010.

${ }^{35}$ Em reportagem publicada no jornal A Gazeta do Povo de Londrina, PR, edição de 15 de abril de 2010.
} 
gasto de mais de $\mathrm{R} \$ 350$ mil. Apenas essa linha de despesa representa quase o triplo do total das receitas declaradas por $\mathrm{el}^{36}$.

O ministro do Supremo Tribunal Federal (STF) e do Tribunal Superior Eleitoral (TSE), José Antonio Dias Toffoli indicou ter uma opinião divergente, ao declarar em entrevista ao jornal O Estado de São Paulo, publicada em 10 de julho de 2010, acreditar que já não haja espaço para as doações em Caixa 2, pelo menos na corrida pela presidência. Toffoli baseia sua argumentação no fato de que os dois principais candidatos à presidência em 2010 teriam registrado no TSE tetos máximos de gastos de campanha no total de R \$ 400 milhões, e que a eleição para presidente no Brasil não poderia custar mais de meio bilhão de reais. Os gastos totais declarados pelos três principais candidatos a presidente foram de $\mathrm{R} \$ 284$ milhões, conforme a tabela 3 a seguir:

Tabela 3

Receita e Gastos declarados pelos três principais candidatos a presidente em 2010

\begin{tabular}{|c|c|c|c|}
\hline \multicolumn{2}{|l|}{} & \multicolumn{2}{c|}{ Valores declarados (R\$) } \\
\hline Candidato & Partido & Receita total & Gastos totais \\
\hline Dilma Roussef & PT & $135.530 .844,32$ & $153.093 .181,16$ \\
\hline José Serra & PSDB & $106.489 .846,91$ & $106.489 .846,91$ \\
\hline Marina Silva & PV & $24.108 .859,74$ & $24.108 .859,74$ \\
& & & \\
\hline & Total & $\mathbf{2 6 6 . 1 2 9 . 5 5 0 , 9 7}$ & $\mathbf{2 8 3 . 6 9 1 . 8 8 7 8 1}$ \\
\hline
\end{tabular}

Fonte:http://spce2010.tse.jus.br/spceweb.consulta.prestacaoconta2010/candidatoServlet.do

A crise do "Mensalão" do governo Lula em 2005 trouxe a público revelações relevantes sobre o Caixa 2 de campanha através dos depoimentos do deputado federal Roberto Jefferson, publicados em diversos jornais à época. Em suas palavras,

\footnotetext{
${ }^{36} \mathrm{O}$ deputado Jocelito Canto anunciou o enceramento de sua carreira pública em agosto de 2010, não concorrendo à reeleição ou a qualquer outro cargo naquele pleito, segundo o próprio devido a incertezas relativas à sua candidatura em decorrência da lei da Ficha Limpa, promulgada naquele ano.
} 
(...) esses fantasmas que ficam rondando o poder sempre são os fantasmas do financiamento eleitoral: Delúbio, PC Farias, Marcos Valério. É sempre a mesma gente. É sempre a mesma prática, porque a legislação eleitoral que nós temos ainda é a de Castelo Branco. Ela não é clara, ela não permite o financiamento político que proteja o doador para que ele não seja escachado como se tivesse querendo comprar os Deputados. (...) Se PC 'faria' - e fez -, hoje, Delúbio e Marcos Valério fazem e outros que virão continuarão a fazer se não mudarmos essas práticas de financiamento eleitoral. Eu trouxe aqui (...) todas as prestações de contas, a minha e a dos senhores; na Justiça Eleitoral. Aí é o princípio da mentira que a gente vive aqui. Esse processo começa na mentira e deságua no PC Farias, deságua nos outros tesoureiros de campanha, agora no Delúbio, no Marcos Valério (apud Campos, 2009, p. 120 , nota 48 ).

Os comentários de Roberto Jefferson, embora não forneçam indícios quantitativos em relação ao Caixa 2, dão conta não apenas de sua existênica e preponderância, mas de sua perenidade, na visão do deputado. A impressão que busca passar aos eleitores e à sociedade em geral é de normalidade e generalidade dessas práticas, contribuindo assim para quebrar a possibilidade de punição dos corruptos pelo eleitor, no momento do voto, ao forjar a percepção de que não há alternativa viável, conforme discutido na seção 3.2 do capítulo anterior.

\subsection{A eleição para governador no estado do Amapá em 2010}

O caso da eleição de 2010 para Governador do Amapá oferece dados interessantes que sugerem a possibilidade de um ponto de comparação entre as contribuições declaradas de campanha e aquelas feitas através de Caixa 2, pelo menos em ordem de 
grandeza. As doações e os gastos de campanha naquele estado, conforme declaradas ao TSE, segundo o site desse tribunal ${ }^{37}$ foram as seguintes:

Tabela 4

Doações declaradas pelos candidatos a governador pelo estado do Amapá em 2010

\begin{tabular}{|c|c|c|c|c|c|c|}
\hline & & Doa & c̃̃es & Votos & Votos & Eleito \\
\hline Nome & Partido & $\mathbf{2}^{\mathbf{a}} \cdot$ parcial & Final & $1^{\circ}$.Turno & $2^{\circ}$.Turno & sim/não \\
\hline $\begin{array}{l}\text { Pedro Paulo Dias } \\
\text { de Carvalho }\end{array}$ & PP & $926.162,95$ & $\begin{array}{r}\text { Não } \\
\text { entregou }\end{array}$ & 44.870 & -- & Não \\
\hline $\begin{array}{l}\text { Carlos Camilo } \\
\text { Goes Capiberibe }\end{array}$ & PSB & $30.000,00$ & $395.200,00$ & 95.328 & 170.277 & Sim \\
\hline $\begin{array}{l}\text { Jorge Emanoel } \\
\text { Amanajas Cardoso }\end{array}$ & PSDB & $1.305 .993,09$ & $1.769 .040,61$ & 93.695 & -- & Não \\
\hline $\begin{array}{l}\text { Genival Cruz de } \\
\text { Araújo }\end{array}$ & PSTU & 0,00 & $4.329,95$ & 2.298 & -- & Não \\
\hline $\begin{array}{l}\text { Luiz Cantuária } \\
\text { Barreto }\end{array}$ & PTB & $281.779,00$ & $1.615 .444,19$ & 96.165 & 146.383 & Não \\
\hline
\end{tabular}

Fonte: http://www.tse.gov.br (acesso em 11 de janeiro de 2011)

Entretanto, uma operação policial cobriu de dúvidas a veracidade dessas declarações de receita. A Polícia Federal (PF) iniciou no dia 10 de setembro de 2010 a Operação Mãos Limpas, no Estado do Amapá, com o objetivo de prender uma organização criminosa composta por servidores públicos, agentes políticos e empresários, que praticava desvio de recursos públicos do Estado do Amapá e da União, conforme disponibilizado no site da instituição ${ }^{38}$. Nessa ocasião, o então governador e candidato a reeleição Pedro Paulo Dias de Carvalho foi preso preventivamente junto com o exgovernador e candidato ao Senado Waldez Goes, de quem havia sido vice, além de mais dezesseis pessoas. Notícia veiculada no jornal O Estado de São Paulo em 12 de setembro de 2010 dá conta de que, segundo o documento do Ministério Público (MP) que embasa os pedidos de prisão temporária ao qual teve acesso aquele jornal, o dinheiro desviado e as propinas cobradas no esquema de desvio de recursos públicos descoberto pela Polícia Federal serviam para financiar a campanha de Pedro Paulo Dias. A argumentação do MP corrobora com a hipótese investigada por este estudo de expressiva relação entre a corrupção política e o Caixa 2 de campanhas eleitorais.

\footnotetext{
${ }^{37}$ http://spce2010.tse.jus.br/spceweb.consulta.prestacaoconta2010/candidatoServlet.do, consultado em 09 de dezembro de 2010.

${ }^{38}$ http://www7.dpf.gov.br/DCS/Resumo_OP_2010.html
} 
A investigação teve por fonte escutas telefônicas realizadas com autorização da justiça no aparelho celular de Lívia Bruna Gato, alegadamente amante do governador. Em uma transcrição dessas gravações o governador relata à sua amante, desde Jacarta, seus planos de pedir ao do Grupo Salim, pertencente a empresários indonésios interessados em investir no Amapá, R\$ 30 milhões para sua campanha à reeleição:

Assim, amor, deixa eu falar uma coisa. Tu não tem ideia do que os caras têm... Porque, no dia seguinte, amor, R \$ 30 milhões para esses caras não é nada. E qual é o custo da minha campanha? Eu, por mais que gastando uma fortuna, não consigo gastar mais do que $\mathrm{R} \$ 20$ milhões ${ }^{39}$.

Não há de se tomar por concretos planos e estratégias eleitorais relatadas em uma conversa pessoal e privada entre um candidato e sua amante. Mas chama a atenção a diferença de magnitude dos gastos efetivamente declarados não apenas por Pedro Paulo, mas por todos os demais candidatos ao governo daquele estado em 2010 frente aos montantes planejados. Parece razoável concluir, ao menos, que R 20 milhões seria um teto máximo plausível para uma campanha eleitoral competitiva a governador naquele estado, segundo a visão do então governador.

O governador não havia, até a data da consulta, 09 de dezembro de 2010, enviado sua prestação final de contas ao TSE, embora o prazo legal tivesse se expirado em novembro. Mas a julgar pelos pouco mais de $\mathrm{R} \$ 900$ mil gastos até a $2^{\mathrm{a}}$ parcial, datada do início de setembro, e decorridos portanto $2 / 3$ da campanha do $1^{\circ}$ turno, fica difícil imaginar que as doações e os gastos declarados pudessem acelerar de tal maneira a alcançar qualquer montante próximo aos R \$ 20 milhões. Cabe observar que, segundo a pesquisa IBOPE registrada no TSE sob o número 6606/2010, disponível no site da instituição ${ }^{40}$, em 31 de agosto daquele ano, menos de uma semana antes do envio da segunda prestação de contas parcial à justiça eleitoral, Pedro Paulo ocupava a terceira posição no ranking com $19 \%$ das intenções de voto, 9 pontos atrás do líder Lucas, e ao mesmo tempo 9 pontos à frente do vitorioso Capiberibe. Esses números indicam que a campanha do governador à reeleição era competitiva antes dos escândalos relatados na operação Mãos Limpas da Polícia Federal virem à tona, o que nos leva a pensar que os

\footnotetext{
${ }^{39}$ Publicada no jornal O Estado De São Paulo em 23 de setembro de 2010.

${ }^{40} \mathrm{http} / / / \mathrm{www}$.eleicoes.ibope.com.br/, consultado em 09 de dezembro de 2010.
} 
gastos realizados até então seguiam os planos do candidato, reforçando a validade da comparação com os montantes declarados pela escuta telefônica.

A mais cara das campanhas a governador para o estado do Amapá nas eleições de 2010 foi a de Luca Barreto do PTB, totalizando R\$ 1,6 milhões, incluídos aí os gastos com o segundo turno. A campanha vencedora de Capibaribe declarou apenas R 395 mil.

Essa comparação lança uma dúvida sobre a eficácia do controle das doações e gastos de campanha pela justiça eleitoral, reforçando a opinião de Speck, para quem "esse fenômeno de Caixa 2 indica sérias falhas quanto à fiscalização da prestação de contas e a punição de transgressores" (2006, p. 158). O autor menciona que "os escândalos políticos que sacudiram o país durante o ano de 2005 tiveram forte vinculação com o tema do financiamento da política. Parte das revelações se referiu às prestações de contas incompletas de partidos e candidatos" (Speck, 2006, p. 158).

Esse caso serve de exemplo do impacto da corrupção política sobre a eficácia do accountability vertical e sobre a qualidade da democracia, conforme discutido nos capítulos anteriores. Naturalmente que as intenções declaradas pelo governador de pedir dezenas de milhões de reais em doações a um investidor estrangeiro seriam acompanhadas de contrapartida na forma da sobrevaloração dos interesses dos doadores, prejudicando a responsividade daquele governo à preferência da maioria dos cidadãos. Ao mesmo tempo, o emprego de parte expressiva dessa quantia (até 2/3) na campanha teria implicado, se levada a cabo, em um fator importante a favor da reeleição do governador, afetando a competição e neutralizando a possibilidade de punição aos corruptos pelos cidadãos eleitores no momento do voto. 


\subsection{Limites legais e doadores "laranja" - a investigação conjunta do TSE e da Receita Federal}

A legislação eleitoral estabelece limites para os doadores contribuírem com campanhas eleitorais, de $2 \%$ do faturamento bruto no caso de empresas e de $10 \%$ da renda para pessoas físicas, ambos referentes à declaração de rendimentos feita à Receita Federal no ano anterior ao pleito para o qual as doações se destinam. As sanções incluem o pagamento de multa no valor de cinco a dez vezes a quantia doada em excesso. As empresas podem ainda ficar proibidas de participar de licitações públicas ou celebrar contratos com o poder público pelo período de cinco anos.

Embora a lei $n^{\circ}$. 9.504 que regulamenta esses limites seja de 1997, a justiça eleitoral não vinha fiscalizando o cumprimento dos mesmos de forma massiva até as eleições de 2006. Apenas processos isolados, iniciados principalmente por denúncias, corriam nos Tribunais Regionais Eleitorais (TRE's), sempre enfrentando a dificuldade da necessidade de aprovação judicial para quebra do sigilo fiscal. No início de 2009, o TSE e a Receita Federal concluíram investigação inédita que, segundo notícia publicada no jornal O Estado de São Paulo em 06 de junho de 2009, identificou 18,3 mil empresas e pessoas físicas que teriam feito doações de campanha acima dos limites estabelecidos por lei, e, portanto, suspeitas de ilegalidade, aos candidatos a deputado, senador, governador e presidente da República nas eleições de 2006. Esse número representa 13,3\% do total de doadores, somando coletivamente $\mathrm{R} \$ 328$ milhões em doações aos candidatos de todo país naquele pleito, ou 20,9\% do total das doações declaradas para todos os cargos e candidatos em 2006, que foi de $\mathrm{R} \$ 1.566,9$ milhões, segundo o sítio de internet às $\operatorname{claras}^{41}$ da organização Transparência Brasil.

Não é automática a dedução de que esses recursos doados de forma declarada por empresas que não têm receitas para justificar tais doações ou por cidadãos que muitas vezes nem sequer declaram imposto de renda sejam em sua maioria um mero mecanismo de transformar doações feitas em Caixa 2 em doações declaradas. Nem se faz possível

\footnotetext{
${ }^{41}$ http://www.asclaras.org.br/2006/, acessado em 10 de dezembro de 2010.
} 
aplicar métodos científicos baseados em evidências empíricas para testar se tais doadores oficiais não passam efetivamente de "laranjas"42 "esquentando" doações frias de doadores ocultos que doam através de Caixa 2. Entretanto, é possível fazer um exercício de exclusão de outras alternativas, o que serve para fortalecer tal hipótese.

Há que se considerar o caso, discutido em detalhes mais à frente, das empresas que não declaram todas as suas receitas, operando algum nível de Caixa 2 em seus negócios. Isso em geral se faz com fins a sonegação de impostos, ou em função de exercício de atividade ilegal, incompatível com a declaração ao físco. Uma doação considerada ilícita por exceder o limite de $2 \%$ do faturamento declarado à Receita Federal por uma dessas empresas pode, na verdade, representar menos de $2 \%$ do faturamento real desse doador, se forem considerados seus rendimentos ocultos. Da mesma forma, pessoas físicas que vivem na ilegalidade fiscal, com rendimentos não declarados à Receita, podem ter rendimentos ocultos que justifiquem suas doações declaradas à Justiça Eleitoral. Essa hipótese de que tais empresas e cidadãos estariam doando recursos que são efetivamente oriundos de seus próprios rendimentos, ainda que ilícitos por não serem devidamente declarados à Receita Federal, parece não parar em pé diante da pergunta de quais motivações e incentivos teriam tais empresas e pessoas para doar de forma declarada? Não seria mais simples, desejando-se contribuir para uma determinada campanha, fazê-lo através do Caixa 2? Essa seria uma ilegalidade muito menos suscetível de fiscalização, e absolutamente em linha com a ilegalidade fiscal em que eles já vivem.

Outra explicação alternativa passível de desmonte é a de que as ilegalidades encontradas pela investigação seriam de pequenos desvios por descuido dos doadores, porém dentro de patamares que possam ser considerados razoáveis, ainda que ilegais. $\mathrm{O}$ TSE não divulgou detalhes da investigação, e a imprensa não obteve ou optou por não publicar detalhes da lista de doações suspeitas, o que facilitaria o teste desta hipótese. Mas pode-se fazer uma avaliação dos limites estabelecidos em lei de $2 \%$ do faturamento bruto frente à lucratividade das empresas. Desse faturamento, a empresa tem que descontar os tributos diretos embutidos em seus preços como o PIS/COFINS, o IPI no caso das indústrias e o ISS no caso de empresas de serviços. Digamos que a receita líquida dessa empresa seja $85 \%$ da receita bruta para esse exercício hipotético. As margens de lucro bruto de uma empresa variam de acordo com seu ramo de atividade e

\footnotetext{
${ }^{42} \mathrm{O}$ termo "laranja" é utilizado no seu sentido popular, como sendo aquele que assume a culpa no lugar do outro; pessoa ingênua, simples ou sem importância; pessoa que substitui outra em muitas situações
} 
eficiência operacional. Tomando $20 \%$ do rendimento líquido como um valor médio razoável da lucratividade, chega-se ao lucro bruto de tal empresa de $17 \%$ de seu faturamento bruto. Descontando-se o Imposto de Renda à alíquota empresarial de 34\%, resta a uma empresa saudável pouco mais de $11 \%$ do seu faturamento bruto como lucro líquido. Imaginar que 1/5 ou mais desse montante seja doado como doação de campanha é uma suposição pelo menos improvável. Em outras palavras, os limites legais são razoavelmente altos, a ponto de não ser plausível a possibilidade de tantos doadores, 13,3\% do total, doarem acima desse limite de forma legítima, quer dizer, doarem recursos que efetivamente lhe pertencem. David Samuels afirma que "embora a lei limite as contribuições de empresas a $2 \%$ de sua renda bruta, isso de facto quer dizer que não há limite para a doação das empresas" (Samuels, 2006, p. 141).

Se acreditarmos que empresas e cidadãos que possuam rendimentos não declarados tenderiam a doar pelo Caixa 2, de forma não declarada, e considerando a improbabilidade de que empresas façam doações com recursos próprios acima dos limites estabelecidos, somos levados a suspeitar que grande parte das 18 mil doações suspeitas de ilegalidade identificadas pela investigação do TSE em conjunto com a Receita Federal sobre as eleições de 2006 representem casos de doações Caixa 2 "esquentadas" - ou seja, trazidas da ilegalidade oculta para a legalidade declarada - por doadores "laranja". O motivo que leva os candidatos a operar tais esquemas é a necessidade de manter um equilíbrio entre receitas e despesas declaradas, conforme discutido mais à frente nesse capítulo.

$\mathrm{Na}$ opinião do procurador regional eleitoral do Mato Grosso do Sul, Pedro Paulo Grubits, "quanto mais díspar for o valor da doação do valor apresentado à Receita, maior chance de Caixa $2 " 43$.

O resultado da referida investigação foi encaminhado ao Ministério Público pelo TSE, então sob a presidência do Ministro Carlos Ayres Britto, no início de 2009, para representação contra os supostos doadores ilegais, segundo Matéria de 11 de maio de 2010 da Folha de São Paulo. Poucos meses depois, entretanto, o próprio TSE, já então sob a presidência do Ministro Ricardo Lewandowski, limitou a possibilidade de o Ministério Público investigar doações ilegais. Isso se deu pela decisão de que os

\footnotetext{
${ }^{43}$ Segundo entrevista concedida ao jornal O Estado de São Paulo e publicada em 6 de junho de 2010.
} 
procuradores não podem obter diretamente da Receita Federal dados sobre faturamento e rendimento de doadores a partidos e candidatos, sem autorização para quebra do sigilo fiscal emitida pela justiça, conforme publicado em acórdão de 29 de abril de $2010^{44}$. O TSE acatou que o MP poderia apenas pedir que a Receita Federal informasse se uma determinada empresa ou pessoa física teria ultrapassado o limite legal, porém não poderia ter acesso direto às informações de rendimentos, sob proteção do sigilo fiscal ${ }^{45}$.

Outra limitação imposta ao Ministério Público na fiscalização das doações ilegais de campanha feitas por empresas e pessoas físicas ocorreu em maio de 2010, quando o TSE, no julgamento do Recurso Especial $n^{\circ} 36.552$, determinou que o prazo para a propositura de representação por descumprimento dos limites legais de doação para campanha eleitoral por pessoa física ou jurídica é de 180 dias contados a partir da diplomação, conforme o acórdão de 10 de agosto de $2010^{46}$. Tal restrição pôs a perder não apenas os referidos 18,3 mil processos encaminhados pelo TSE ao MP, mas também alguns milhares de processos em curso no MP iniciados por outras fontes de denúncia.

Esse episódio exemplifica a impunidade decorrente da ineficácia do monitoramento e fiscalização das contas de campanha pela Justiça Eleitoral, conforme discutida na seção 3.4 do capítulo anterior, e dá conta de um dos alicerces fundamentais do mecanismo de incentivos à prática da corrupção política e ao uso do Caixa $2 \mathrm{em}$ campanhas aos quais estão submetidos os atores políticos.

\footnotetext{
${ }^{44} \mathrm{http}: / /$ www.tse.gov.br/internet/jurisprudencia/index.htm, consultado em 10 de dezembro de 2010.

${ }^{45}$ É interessante observar a discordância à época entre o presidente e o ex presidente daquela corte, uma vez que, nesse acórdão, o ministro Carlos Ayres Britto foi voto vencido.

${ }^{46} \mathrm{http} / / /$ www.tse.gov.br/internet/jurisprudencia/index.htm, consultado em 10 de dezembro de 2010.
} 


\subsection{Doações ocultas - Anonimato ou Caixa 2 "esquentado"?}

De acordo com a lei dos partidos políticos, $\mathrm{n}^{\circ} .9 .095$ de 19 de setembro de 1995, o partido político pode receber doações de pessoas físicas e jurídicas para constituição de seus fundos. Não há na lei quaisquer limites máximos para tais doações. Como os partidos podem fazer doações aos candidatos, estabelece-se assim um mecanismo para que as doações sejam feitas de forma legalmente declarada, porém sem as limitações e sansões previstas na lei 9.504/97 que regulamenta as doações feitas diretamente aos candidatos e comitês financeiros de campanha.

Esse mecanismo ficou conhecido no meio político e na mídia como "doação oculta”. Tal nomenclatura advém do fato de que, até as eleições de 2008 (o TSE mudou a interpretação da lei dos partidos para o pleito de 2010, conforme discutido mais à frente neste capítulo), os partidos não eram obrigados a declarar as origens específicas dos montantes doados a seus candidatos. Somente em abril de cada ano os partidos estão obrigados a fazer sua prestação anual de contas à Justiça Eleitoral, incluindo as doações recebidas, mas, pela lei, estavam desobrigados de apontar o beneficiário final do recurso recebido em doação. Dessa forma não havia registro no TSE relacionando os doadores aos candidatos para quem suas doações se destinavam.

Uma consequência da falta de publicidade dessas doações é o prejuízo ao processo decisório do eleitor, com impacto sobre a qualidade da democracia na sua dimensão de accountability vertical, uma vez que as doações recebidas são componente importante das propostas dos candidatos, conforme discutido nos capítulos anteriores.

Embora esse mecanismo estivesse disponível a doadores e candidatos há mais de uma década, apenas a partir das eleições de 2008 observou-se uma mudança de estratégia por parte de doadores e candidatos receptores de doações, no sentido de uma utilização mais expressiva das doações ocultas. A tabela 5 mostra o percentual de doações ocultas, ou seja, do partido, no total de doações recebidas pelo candidato e seu comitê de campanha nas eleições majoritárias para governador e prefeito das respectivas capitais dos três estados brasileiros com maior colégio eleitoral, Minas Gerais, Rio de Janeiro e 
São Paulo, nos pleitos de 2006, 2008 e 2010, segundo dados das prestações de contas disponíveis no sítio eletrônico do TSE na internet ${ }^{47}$. As doações totais são a soma das doações apresentadas na prestação de contas do candidato, menos aquelas feitas pelo comitê de campanha de sua candidatura específica, consideradas como transferência entre contas de campanha, mais as doações feitas a esse comitê. Doações do partido são aquelas feitas pelos diretórios municipal, estadual ou nacional do partido diretamente ao candidato ou ao comitê de sua campanha. A comparação entre corridas para governador e prefeito pode embutir possíveis distorções que merecem cuidado adicional na avaliação dos dados, porém se fez relevante precisar o ponto de início dessa nova estratégia, que foi 2008, quando esse artifício foi utilizado em 17 das 26 campanhas vitoriosas nas capitais do país, segundo publicou a Folha de São Paulo em 06 de dezembro de 2008. Dos R 115 milhões em receitas declaradas pelos prefeitos eleitos nas capitais brasileiras naquele pleito, R \$ 41 milhões ou $36 \%$ foram oriundos de doações ocultas, e, portanto, tinham sua verdadeira origem desconhecida da Justiça Eleitoral, dos eleitores e da sociedade em geral, sendo de conhecimento apenas dos doadores, das lideranças partidárias e dos próprios candidatos.

47 http://www.tse.gov.br 
Tabela 5

Doações ocultas em \% das receitas totais

\begin{tabular}{|c|c|c|c|c|}
\hline & & Do & č̃es & \\
\hline Estado & Candidato & Partido (R\$ mil) & Totais (R\$ mil) & $\%$ \\
\hline & & 2006 & & \\
\hline$\overline{\mathrm{MG}}$ & Aecio Neves & 439 & 19.683 & $2,2 \%$ \\
\hline RJ & Sergio Cabral & 0 & 9.740 & $0,0 \%$ \\
\hline SP & José Serra & 0 & 26.748 & $0,0 \%$ \\
\hline & Sub total & 439 & 56.171 & $\mathbf{0 , 8 \%}$ \\
\hline & & 2008 & & \\
\hline MG & Márcio Lacerda & 9.114 & 19.306 & $47,2 \%$ \\
\hline $\mathrm{RJ}$ & Eduardo Paes & 5.209 & 12.685 & $41,1 \%$ \\
\hline $\mathrm{SP}$ & Gilberto Kassab & 18.233 & 36.288 & $50,2 \%$ \\
\hline & Sub total & 32.556 & 68.279 & $47,7 \%$ \\
\hline & & 2010 & & \\
\hline MG & Antonio Anastasia & 18.009 & 38.037 & $47,3 \%$ \\
\hline RJ & Sergio Cabral & Não Disponível ${ }^{48}$ & 18.659 & $0,0 \%$ \\
\hline$\overline{\mathrm{SP}}$ & Geraldo Alckmin & 10.095 & 41.705 & $24,2 \%$ \\
\hline & Sub total & 28.104 & 98.401 & $28,6 \%$ \\
\hline
\end{tabular}

Esse quadro mostra que as doações ocultas, praticamente inexistentes nesses três estados em 2006, ganharam grande relevância em 2008, representando quase a metade das receitas declaradas por esses três candidatos vitoriosos. Segundo o jornal O Globo ${ }^{49} \mathrm{o}$ total das doações ocultas em todo o país saltaram de $\mathrm{R} \$ 68,4$ milhões ou 4,8\% do total em 2006 para R \$ 251,4 milhões ou 8,9\% do total em 2008. O mesmo jornal dá conta de que as doações ocultas já começavam a ser usadas em 2006 pelas campanhas presidenciais,

\footnotetext{
${ }^{48}$ As prestações de contas referentes à campanha vitoriosa de Sergio Cabral do PMDB para governo do estado do Rio de Janeiro em 2010 apresentam considerável dificuldade no sentido de identificação de doações de partidos, bem como na associação do doador com um candidato específico, uma vez que aquela campanha se valeu de um comitê de campanha único para o partido no estado, o qual recebeu doações de comitês estaduais de diversos outros partidos da ampla coligação e distribui recursos tanto para o comitê único do governador quanto para comitês de alguns candidatos a deputado estadual e a deputado federal do PMDB e de outros partidos. Além disso, esse comitê único arcou diretamente com despesas de campanha, sem que seja possível identificar a que candidato tais despesas teriam beneficiado. ${ }^{49}$ Em matéria publicada em 14 de março de 2010.
} 
representando $17 \%$ de todos os recursos arrecadados tanto pelo candidato vencedor Lula quanto por seu maior concorrente Alckmin, num total de $\mathrm{R} \$ 21,7$ milhões.

Embora sem dados disponíveis suficientes para permitir uma conclusão quanto às causas de tal mudança, uma vez que seria necessária pesquisa empírica específica que não é escopo deste estudo, é possível suspeitar que a atenção dada pelo TSE às doações acima dos limites legais através de ampla investigação abrangendo todos as doações pela primeira vez em 2006 tenha sido um dos fatores que levou a essa mudança de estratégia com a adoção maciça das doações ocultas em 2008.

Como era de se esperar, não foi essa a justificativa apresentada publicamente pelos candidatos em 2008 quando questionados sobre o por que das doações ocultas terem ganhado tanta importância no total das receitas declaradas pela primeira vez naquele ano. Segundo esses, as doações ocultas seriam uma escolha dos doadores em busca de anonimato para se protegerem de eventuais retaliações caso seus candidatos viessem a perder as eleições - uma explicação à qual falta uma lógica temporal, já que tal pressão, se existente e preponderante, já estaria presente nas eleições anteriores. Fato realmente novo em 2008 foi a atenção dada pelo TSE às doações acima dos limites legais em 2006.

As eleições de 2010 trouxeram outro fato relevante que desafia a explicação baseada no desejo dos doadores pelo anonimato apresentada pelos candidatos e partidos envolvidos com as doações ocultas. O TSE, através da resolução $\mathrm{n}^{\circ} .23 .217$ de 02 de março de $2010^{50}$, estabeleceu que em ano eleitoral, os partidos políticos poderão aplicar ou distribuir pelas diversas eleições os recursos financeiros recebidos de pessoas físicas e jurídicas, o que já era permitido em pleitos anteriores, devendo, obrigatoriamente discriminar a origem e a destinação dos recursos repassados a candidatos e a comitês financeiros, o que constitui uma nova obrigação para o pleito de 2010. Essa medida foi anunciada pelo TSE como visando coibir as doações ocultas que haviam se multiplicado no pleito anterior. A mídia comemorou o que acreditava ser o fim das doações ocultas, e classificou a medida como moralizadora.

A reação dos partidos à época foi de preocupação, contrários à resolução. O jornal O Estado de São Paulo publicou em 04 de março daquele ano que lideranças dos quatro

\footnotetext{
${ }^{50}$ http://tse.gov.br/internet/jurisprudencia/index.htm, consultado em 13 de dezembro de 2010.
} 
maiores partidos políticos - PMDB, PT, PSDB e DEM - reclamaram da resolução do Tribunal Superior Eleitoral (TSE) que restringiu as chamadas doações ocultas e ficaram especialmente preocupados com a decisão do TSE que veio a obrigá-los a discriminar a origem e o destino dos recursos repassados a candidatos e comitês financeiros durante a campanha daquele ano. Na avaliação desses partidos, o montante de doações de campanha seria reduzido nas eleições de 2010, com um aumento das doações para Caixa 2 em decorrência dessa resolução.

Ao analisar o comportamento das doações de campanha feitas em 2010, embora não seja possível verificar se houve aumento das doações feitas via Caixa 2, é possível verificar que as doações declaradas, sejam autênticas ou Caixa 2 "esquentadas", cresceram em 2010 frente aos pleitos anteriores, e de forma substancial, conforme discutido na seção 3.4 do capítulo anterior. Inclusive para presidente houve aumento expressivo nas doações de campanha declaradas pelos dois candidatos mais votados em cada pleito. Enquanto em 2006 Lula e Alckmin declararam coletivamente R\$ 160,3 milhões em doações, em 2010 Dilma e Serra juntos declararam R\$ 255,5 milhões (de acordo com o jornal O Estado de São Paulo de 30 de novembro e de 02 de dezembro de 2010). Além disso, o nível de doações ocultas em 2010 manteve-se ainda elevado, embora tenha mostrado queda em relação a 2008. Se analisarmos apenas as campanhas para governador de Minas Gerais e São Paulo em 2010 contra as campanhas para prefeito das capitais desses estados em 2008, houve aumento absoluto das doações feitas pelos partidos aos comitês que caracterizam doações ocultas, de $\mathrm{R} \$ 27,3$ para 28,1 milhões.

Embora a eficácia na prática dessa medida do TSE venha a depender do nível de clareza das prestações de contas que vierem a ser apresentadas, é fato que a referida resolução, em teoria, acaba com o anonimato dos doadores nas doações feitas através dos partidos, pois ainda que não apareçam listados nas prestações de contas de candidatos e comitês de campanha, os doadores constarão da declaração dos partidos como sendo a origem de doações que estes façam àqueles, evidenciando assim a ligação doador/candidato. Entretanto, a doação feita ao partido segue sendo regulamentada pela lei dos partidos, de $n^{\circ} .9 .095 / 95$, e não pela lei eleitoral $n^{\circ} .9 .504 / 97$, não estando tais doações sujeitas, portanto, às limitações de $2 \%$ do faturamento bruto no caso de empresas ou de $10 \%$ da renda no caso de pessoas físicas. Um doador que não declare imposto de renda pode, portanto, fazer uma doação declarada a um partido e através desse a um 
candidato de forma legal, Embora isso possa levantar suspeitas de crime de sonegação de Imposto de Renda, não constitui ilícito eleitoral, não sendo, portanto, tal doação passível de investigação e denúncia pela Justiça Eleitoral.

As evidências acima sugerem que a real motivação para a adoção do mecanismo de doações ocultas em 2008, após investigação do TSE sobre doações de 2006, e para continuidade de sua utilização em 2010 seja a possibilidade de "esquentar" doações Caixa 2 feitas por doadores que não querem se identificar através de "laranjas", empresas e pessoas físicas, que assumem essas doações como suas, sem ter rendimentos que justifiquem as quantias, escapando por esse mecanismo ao controle da legislação eleitoral.

Desse modo, embora não seja conhecido o valor das doações em Caixa 2 que não são "esquentadas" por "laranjas", pode-se estimar pelas evidências observadas que o Caixa 2 total, incluindo essa parte declarada, se equipara ou excede as doações declaradas com fontes legítimas, o que atesta sua relevância e possível ou mesmo provável preponderância no processo eleitoral brasileiro.

\subsection{Por que uma empresa doa em Caixa 2?}

Como parte do esforço empreendido para alcançar um melhor entendimento do fenômeno do Caixa 2 de campanha, cabe uma investigação sobre as motivações para que doadores e receptores optem pelo Caixa 2 em lugar de doações declaradas à Justiça Eleitoral. Tal esforço investigativo limita-se essencialmente ao campo conceitual, uma vez que se mostrou inexequível pesquisa empírica que permitisse testar hipóteses. Pelo lado dos doadores, o foco serão as empresas, uma vez que já foi constatado que as doações de pessoas jurídicas superam em muito as de pessoas físicas em relevância monetária (Samuels, 2006). 
A prestação de contas de uma campanha precisa apresentar certo equilíbrio entre receitas e despesas, embora haja provisão na lei para as dívidas de campanha, resultantes de receitas de doações inferiores ao total das despesas. Acontece que muitas das despesas de uma campanha eleitoral são de natureza eminentemente visível, pelo propósito a que se destinam, que é o de divulgar um candidato ou partido para o maior número possível de eleitores. Viagens com deslocamento e hospedagem, cabos eleitorais, material gráfico, produção de programas de rádio e televisão, criação de jingles, veículo de som, outdoors, anúncios em jornal e outras mídias impressas são despesas cujo resultado é aparente para os órgãos de fiscalização e a sociedade em geral. Ainda que algumas delas ou o real valor das demais possam ser manipulados na declaração de gastos à Justiça Eleitoral, o fato é que o gasto de campanha tem, por natureza, um certo grau de publicidade. Assim sendo, é de se supor que os atores políticos estejam sob alguma pressão para obter doações declaradas que possam fazer frente a despesas difíceis de ocultar.

Há, entretanto, pelo menos um cenário no qual o candidato se beneficia pelas doações Caixa 2 em lugar de doações declaradas e poderia, portanto, preferi-las. Trata-se da possibilidade de enriquecimento de alguns candidatos com o próprio processo eleitoral, quando as campanhas conseguem arrecadar mais do que foi gasto, restando, ao final, sobras de campanha. Os planos de reeleição do governador do Amapá em 2010, conforme relatados por ele à sua amante, pareciam apontar nessa direção. Se tais sobras forem oficialmente declaradas, sua destinação terá previsão legal, além de notoriedade pública, não podendo, portanto, ser apropriadas pelo candidato e membros do comitê de campanha ao final da eleição. Daí, a vantagem pessoal aferida na opção pelas doações em Caixa 2. Esse pensamento segue uma linha defendida por alguns estudiosos de que também o processo eleitoral faz parte dos mecanismos de financiamento da classe política $^{51}$. Entretanto, com a crescente pressão competitiva entre candidatos e partidos, e em função da pressão por gastos de campanha crescentes a cada pleito, é provável que as sobras de campanha, que foram objeto central de escândalos políticos nos anos 1980 no Brasil, tenham importância menor nas eleições contemporâneas. Assim sendo, acreditamos que muito provavelmente os candidatos e partidos têm incentivos para receber doações declaradas de campanha, pelo menos em proporção maior que a vocação dos doadores em optar pelos meios legais e declarados. Tanto assim o é, que surgem os doadores "laranjas" sugeridos anteriormente, cuja utilidade seria transformar doações em

\footnotetext{
${ }^{51}$ Classe como agrupamento por atividade profissional, e não em seu sentido social
} 
Caixa 2 em doações declaradas que possam fazer frente às despesas declaradas. Levando-se isso em consideração, teria, pois que vir pelo menos em parte dos doadores a pressão pela doação via Caixa 2. Cabe, portanto, investigar os mecanismos de incentivos que possam os estar levando a fazer tal opção.

Uma razão imediata para um doador preferir uma doação não declarada feita através de Caixa 2 para o financiamento de campanha estaria em o ator da doação, pessoa física ou jurídica, possuir receitas oriundas da economia informal. A realidade do Caixa 2 é presente na economia brasileira como um todo em diferentes graus, dependendo do ramo de atividade, tamanho e natureza societária no caso de empresas. Estudo publicado pelo IBPT - Instituto Brasileiro de Planejamento Tributário, estima que o coletivo das empresas brasileiras deixaram de declarar receitas no montante de $\mathrm{R} \$ 1,3$ bilhões em 2008, valores esses recebidos e pagos na forma de Caixa 2 não declarados à Receita Federal (Amaral, Amaral, Olenike \& Steinbruch, 2009). Essa realidade da economia informal brasileira naturalmente tem impacto sobre as práticas de doação de campanha.

Um exemplo extremo desse espectro seriam as doações feitas a partidos ou candidatos por organizações criminosas, normalmente sobre grande pressão para obter favores do Estado que permitam a continuidade de suas atividades ilegais. Citando Mingnardi, Arantes atesta que "o crime organizado não pode existir em larga escala sem algum tipo de acordo ou envolvimento de setores do próprio Estado, especialmente as forças policiais" (Arantes, no prelo, p. 30, tradução nossa) ${ }^{52}$.

Mas também muitos segmentos empresariais ditos lícitos têm um componente expressivo de seu faturamento e consequente circulação financeira não declarada ao fisco. Um exemplo evidente é o setor de alimentos e bebidas, começando pelos pequenos estabelecimentos no varejo, chegando por cadeia aos distribuidores médios e desses aos grandes fabricantes e seus fornecedores. O transporte público realizado por empresas privadas é outra atividade econômica que ainda nos dias de hoje se vale de receitas não declaradas em uma parcela razoável de seus negócios, ainda que menor do que no passado por força de regulamentação e do processo em curso de estatização das receitas de transporte, como é o caso da cidade de São Paulo. Com seus interesses enraizados

\footnotetext{
${ }^{52}$ A exoneração em junho de 2010 do secretário nacional de Justiça, Romeu Tuma Júnior, suspeito de envolvimento com o chinês Li Kwok Kwen, conhecido como Paulo Li, acusado de contrabando, em junho de 2010 pode ser interpretada como um exemplo recente desse fenômeno.
} 
principalmente nos municípios, e sendo uma atividade quantitativamente representativa em relação aos orçamentos da esfera municipal, isso pode levar a que as campanhas de vereadores e prefeitos tenham uma parcela das doações feitas em Caixa 2 por empresas operadoras do transporte público municipal. Essa suspeita pode merecer investigação subsequente, na busca de evidências empíricas para as proposições aqui apresentadas, o que não é, entretanto, objeto desta dissertação.

O raciocínio acima poderia levar à investigação da raiz do fenômeno político eleitoral do Caixa 2 para a esfera econômica: recursos financeiros que circulam na economia informal alimentando contribuições não declaradas a políticos e partidos. Como coloca Samuels, "dinheiro do Caixa 2 em geral não é dinheiro limpo" (2006, p.149). Tal explicação parece, entretanto, incompleta. A lógica da origem fria do dinheiro doado em Caixa 2 é desafiada pelas evidências encontradas em investigações conduzidas pela Polícia Federal em conjunto com o Ministério Público sobre doações desse tipo feitas por empresas de grande porte do ramo de construção. Essas empreiteiras têm seu faturamento essencialmente oriundo do setor público, tendo, portanto, seus ingressos financeiros declarados e conhecidos. Segundo Samuels, os grandes doadores de campanhas eleitorais no Brasil são empresas dos setores grandemente influenciados por regulamentação governamental, ou muito dependentes de contratos públicos: bancos, setor financeiro, indústria pesada, construção civil (Samuels, 2006). São segmentos de negócios que não têm receitas ocultas expressivas em suas operações.

A doação não declarada, feita em Caixa 2 por uma empresa que tem suas receitas perfeitamente declaradas tem desvantagens e acarreta ônus adicional, se comparada a uma doação legalmente declarada à justiça eleitoral. O processo de esfriar o dinheiro, que consiste em dar saída do caixa fiscal declarado da empresa para alguma forma de Caixa 2, além de implicar em custos, debilita os controles internos da empresa, expondo-a a desvios e roubos por parte de seus próprios funcionários e da cadeia envolvida no processo de esfriamento e doação.

Pode ser considerado um exemplo de tais riscos as suspeitas levantadas durante as eleições presidenciais de 2010 sobre o ex-diretor da DERSA-SP, conhecido como Paulo Preto, referentes ao suposto desaparecimento de $\mathrm{R} \$ 4$ milhões doados através de Caixa 2 à campanha de José Serra do PSDB pela construtora Odebrecht, responsável pela execução das obras bilionárias do trecho sul do Rodo Anel, importante complexo viário 
daquele estado, enquanto Serra era governador. Além disso, há o risco jurídico e de imagem que representa a prática ilegal de Caixa 2.

A operação "Castelo de Areia” da Polícia Federal, deflagrada em março de 2009, traz outro possível exemplo desses riscos, respeitando-se aqui o fato de que tal operação apontou apenas para um indício de crime, e com os devidos cuidados de não tomar investigados por indiciados e muito menos por condenados. As investigações dessa operação, que atingiu entre outras a empreiteira Camargo Correa, tiveram por ponto de partida o monitoramento de remessas de dólares ao exterior através de operações conhecidas como dólar-cabo, e resultaram na identificação de crimes de evasão de divisas, operação de instituição financeira sem a competente autorização, formação de quadrilha, lavagem de dinheiro e fraude a licitações, conforme informado pelo site da Polícia Federal ${ }^{53}$. É interessante observar dois fatos em particular no caso específico da Camargo Correa, que teve quatro diretores do seu quadro de funcionários com a prisão preventiva decretada durante a operação. O primeiro é que não parecia estar claro até que ponto esses funcionários agiam em total acordo com a alta direção da empresa. Os montantes esfriados da contabilidade oficial e transacionados no exterior seriam para pagar agentes públicos pelo favorecimento em licitações, licenças ambientais e inspeção de obras, em suma, corrupção política praticada com o aval da empresa controladora, havendo evidências de que tinham autonomia interna para praticar tais atos. Mas suspeita-se que também teria havido desvio de dinheiro da empreiteira com finalidade ao enriquecimento dos referidos diretores, em desacordo com a matriz e sem o seu conhecimento.

O outro fenômeno interessante relacionado a essa operação foram as referências a "contribuições não declaradas de campanha" feitas a políticos tanto da base aliada quanto da oposição, e flagradas em escutas telefônicas da PF que visavam a investigar crimes eminentemente financeiros, indicando relação direta nesse caso entre a corrupção política e o Caixa 2 de campanha, ao mesmo tempo que explicitando os riscos de tal prática para as empresas que dela participam. Uma planilha eletrônica apreendida na Operação Castelo de Areia sugere que a Camargo Corrêa doou a políticos nas eleições de 2006 R \$ 4 milhões em dinheiro, sem recibo nem registro no TSE, segundo notícia do jornal A Folha de São Paulo publicada em 23 de janeiro de 2010. As evidências de crime eleitoral

\footnotetext{
${ }^{53}$ http://www7.dpf.gov.br/DCS/noticias/2009/Marco/25032009_OpCastelodeAreiaSP.html, consultado em 14 de dezembro de 2010.
} 
coletadas nessa operação foram encaminhadas à Justiça Eleitoral, segundo declaração da Polícia Federal. A não continuidade das investigações pelo TSE, pelo menos até o momento desta dissertação, pode ser um sintoma do problema apontado por Taylor para quem

a dificuldade em se punir infrações deve-se, em parte, à separação institucional da Justiça Eleitoral de outras instituições jurídicas: isto é, da existência de esferas diferentes da justiça para tratar de assuntos de corrupção por políticos governantes, e, outra, para tratar de irregularidades eleitorais, mesmo que a prática da corrupção pelos governantes muitas vezes seja incentivada pelas demandas do sistema eleitoral (Taylor, 2006, p. 150).

Como explicar então que, mesmo diante desses incentivos contrários, as contribuições de campanha feitas em Caixa 2 tenham espaço nesse ambiente empresarial? Os mecanismos explicativos sugeridos a seguir estão focados nos incentivos a que estão submetidos os atores empresariais de médio e grande porte, mesmo aqueles cujas atividades econômicas se desenvolvem primordial ou exclusivamente na formalidade fiscal, e que os levam a fazer a opção pelo Caixa 2 como forma de realizarem suas doações de campanha eleitoral. Essa escolha de abordagem está em linha com o racional de Arantes, para quem,

pensando em termos da qualidade da democracia, parece claro que a melhor forma de entender e predizer a direção que a accountability pode tomar no regime democrático brasileiro é analisando a motivação individual dos atores e os efeitos produzidos pelas instituições que eles habitam (Arantes, no prelo, p. 39, tradução nossa).

A primeira explicação, e muitas vezes a adotada pelos candidatos receptores das doações Caixa 2, quando essas se tornam acidentalmente públicas, é a opção pelo anonimato feita pelos doadores. Apesar de muitas dessas empresas doarem também de forma declarada, e, portanto, pública aos mesmos candidatos, essa explicação pode ter raízes na fragmentação partidária característica do sistema político brasileiro. A elevada concorrência entre uma multiplicidade de partidos, ou no caso da corrida legislativa a competição interna entre candidatos de um mesmo partido ou coligação coloca os doadores em uma difícil posição na qual uma doação expressiva a um candidato ou partido lhes o assegura acesso a e a cooperação de uma parcela pequena do apoio necessário, enquanto sua publicidade pode gerar antagonismo de políticos concorrentes, que poderiam render saldo negativo a quem doa a uns, pela retaliação indesejável dos 
demais. Desse modo, a doação em Caixa 2 visaria ocultar dos demais políticos o favorecimento a um ou outro. Soma-se a isso o fato de que as contribuições são feitas a múltiplos partidos e candidatos concorrentes, sem que fique claro para nenhum quais as reais preferências do doador, e fica assim assegurada a compra da boa vontade de uns sem o efeito colateral da animosidade negativa dos outros.

Uma expressão desse receio de retaliação pode ser encontrada na entrevista concedida pelo bem sucedido empresário brasileiro Eike Batista, dos ramos de mineração e petróleo - ambos com grande dependência de regulamentações e concessões do governo - ao programa Roda Viva da TV Cultura em 30 de agosto de 2010, reproduzida parcialmente em reportagem do jornal O Estado de São Paulo, publicada em 31 de agosto daquele ano. Na ocasião, o empresário declarou sua estratégia de doar aos dois candidatos melhor posicionados nas pesquisas de intenção de voto para presidente, justificando que "escolhemos ter uma democracia. Para que a democracia fique em pé, eu tenho que ajudar que ela se sustente. Então, financio os dois candidatos. Em prol da democracia". Pressionado pelos entrevistadores e perguntado sobre o receio de retaliação, ele terminou concordando que "é isso também, claro que eu tenho". No mesmo pleito presidencial de 2010, o Grupo Gerdau declarou doações para a candidata Dilma do PT e para o seu concorrente direto, o candidato Serra do PSDB, com uma particularidade: a doação para Dilma foi de R $\$ 1,5$ milhão - e o dobro para seu rival José Serra: R \$ 3 milhões, segundo notícia publicada no jornal O Estado de São Paulo em 02 de dezembro de 2010. O Banco ITAU fez em 2010 doações declaradas diretas aos três candidatos a presidente melhor classificados nas pesquisas de intenção de voto: $\mathrm{R} \$ 4$ milhões à Dilma, $\mathrm{R} \$ 4$ milhões ao Serra e R\$ 1 milhão à Marina ${ }^{54}$.

O segundo mecanismo explicativo para a opção pelas doações feitas através de caixa 2 leva em consideração a relação de poder entre doador e receptor, e sugere a possibilidade de um instrumento de controle das empresas que doam sobre os candidatos, uma vez eleitos. Faltam dados que permitam uma comprovação empírica de tal suposição, porém as observações descritivas sugerem que tal mecanismo esteja operando em algum nível. Parta-se do princípio de uma relação entre a corrupção política e as doações de campanha feitas em Caixa 2. Embora tal relação ainda careça de confirmação, adotemo-la como premissa válida por um instante. Existiria, portanto, uma ilegalidade

\footnotetext{
${ }^{54}$ http://spce2010.tse.gov.br/spceweb.consulta.prestacaoconta2010/candidatoServlet.do, consultado em 14 de dezembro de 2010.
} 
associada à doação de campanha em questão que antecede e independe da escolha pelo mecanismo também ilegal da doação feita via Caixa 2, que é a prática da corrupção política correspondente. Nesse caso, ocultar o ato da doação serviria a dois propósitos: um, o de não chamar a atenção pública para a ilegalidade original; e o outro, como forma de controle sobre os atores políticos, uma vez que a publicidade de tais atos ilegais atingiria o político eleito que tivesse recebido doações Caixa 2 enquanto candidato. Além disso, eventuais punições associadas a doações ilegais de campanha têm, na prática, consequências potencias desproporcionalmente maiores para candidatos receptores, que podem perder o mandato, se eleitos, e tornarem-se inelegíveis por oito anos, do que para os doadores, sujeitos muitas vezes apenas a multa passível de recursos e apelações. Também pesa a favor do doador o fato de que os políticos são, em geral, muito mais dependentes da opinião pública do que empresas e empresários. Por fim, a julgar pela postura da mídia diante da maioria dos escândalos de corrupção, parece existir no Brasil o fenômeno da corrupção praticada apenas pelo corrupto, uma vez que se dá pouca atenção ao corruptor, ficando todo o foco no corrompido.

Embora fossem necessárias evidências empíricas mais sólidas para permitir relacionar o ocorrido com a explicação proposta acima, o fato é que, conforme reportagem publicada no jornal A Folha de São Paulo, em 22 de novembro de 2010, o Superior Tribunal de Justiça decidiu pela suspensão definitiva da operação Castelo de Areia, confirmando suspensão provisória aplicada no início do ano. A justificativa dada pelo presidente do Superior Tribunal de Justiça (STJ), Ministro César Asfor Rocha, foi o uso de uma denúncia anônima para pedir autorização para instalar escutas telefônicas “genéricas". Essa decisão, segundo pesquisa encomendada por aquele jornal, contraria jurisprudências anteriores e posteriores daquela corte, inclusive emitidas pelo próprio Ministro Asfor Rocha.

Outro caso que serve de exemplo dessa impunidade de crimes eleitorais envolvendo empreiteiras, identificados de forma acidental ou colateral em operações da PF e do MP aconteceu em maio de 2009. A polícia apreendeu uma pasta intitulada "Eleições 2008" na sede da empreiteira OAS, em operação de busca e apreensão da Polícia Federal solicitada pelo Ministério Público Federal na investigação do desvio de $\mathrm{R}$ \$ 30 milhões nas obras do complexo viário Rio Baquirivu, em Guarulhos, na Grande São Paulo, sob responsabilidade da construtora. Esse caso chama a atenção nem tanto 
pelo conteúdo ou pelos montantes envolvidos no suposto desvio, mas pelo fato relevante de que a Justiça Federal ordenou a devolução da pasta à empresa, e proibiu que fosse feita cópia da mesma. Isso, apesar da ligação percebida pelo procurador Matheus Baraldi Magnani entre a contratação da OAS e a pasta de doações, e mesmo sob a suspeita do Ministério Público Federal de que os repasses teriam abastecido Caixa 2 de parlamentares e candidatos a prefeito daquela cidade. Possivelmente também mais um exemplo dos efeitos colaterais da separação da Justiça Eleitoral do restante do judiciário, apontado por Taylor (Taylor, 2006), e mais uma evidência de relação entre corrupção e Caixa 2 de campanha.

Esses casos apresentam pontos em comum que merecem ser comentados. Em ambos, o alvo das operações a que estavam submetidas as empreiteiras não eram originalmente crimes eleitorais, porém as evidências coletadas nas buscas e apreensões apontaram para tais suspeitas, de forma colateral. Tanto a OAS quanto a Camargo Correa mantinham registros documentais das supostas doações feitas em Caixa 2. Por fim, a interrupção das investigações não causou, em nenhum dos dois casos citados como exemplos, maiores reações adversas no meio político. Não se apresentaram representantes da oposição demandando o esclarecimento dos fatos e a continuidade das investigações na intensidade que seria de se supor, dadas a gravidade dos crimes apontados, a força das evidências coletadas e o absurdo das ordens judiciais em favor das empreiteiras. Essa omissão pode ser interpretada como indício de mau funcionamento do accountability horizontal que deveria ser exercido pelo legislativo e pela oposição, e levanta suspeitas de que uma parcela expressiva da classe política esteja comprometida com os esquemas de doação em Caixa 2 promovidos pelas grandes empreiteiras. Notícias na mídia secundária como sites na internet, blogs e afins, mas que não tiveram espaço nos principais veículos de mídia impressa brasileira, dão conta de que no início de 2010 apenas o Senador Pedro Simon do PMDB/RS, à luz das revelações feitas por essas operações da PF e dos entraves impostos pelo judiciário para a continuidade das investigações, seguia defendendo sozinho e de forma isolada a criação de uma Comissão Parlamentar de Inquérito das empreiteiras, reavivando proposta antiga sua, já apresentada pelo senador em anos anteriores, igualmente sem apoio de seus colegas parlamentares.

As observações descritas e debatidas acima sugerem que as doações de campanha feitas em Caixa 2, uma vez constantes de registros privados, além de servirem de ameaça 
constante aos políticos eleitos com a ajuda recebida, como uma memória dos compromissos assumidos, provêem uma forma de blindagem dos doadores por atrelarem na forma de evidências suas eventuais ações ilegais aos ilícitos eleitorais de uma gama ampla de políticos e partidos. O processo pelo qual o Poder Judiciário dá cobertura a esses esquemas que entrelaçam corrupção política e Caixa 2 de campanha não foi objeto desta dissertação, por falta de material e tempo para expansão da abrangência deste estudo. Mereceria, porém uma investigação mais aprofundada, pela importância que tem para o funcionamento continuado de tais esquemas, e fica aqui proposto como tema de estudos posteriores. Já a aceitação pacífica de tais acobertamentos pelo meio político corrobora a hipótese defendida da generalização e preponderância das doações em Caixa 2 no financiamento de campanhas eleitorais no Brasil e da relação desse fenômeno com a corrupção política.

O presente capítulo concentrou-se mais em examinar a lógica dos incentivos institucionais sobre os financiadores de campanha e os atores políticos que os induz a determinados tipos de comportamento, em especial à prática da corrupção política e ao uso de Caixa 2 de campanha do que em mensurar empiricamente tais fenômenos. Tal medição não foi possível até o momento porque a estrutura de incentivos institucionais não favorece que os atores envolvidos venham a dar publicidade aos seus atos. Ao mesmo tempo, a Justiça Eleitoral e demais instituições do judiciário não operam no sentido de quebrar as práticas de segredo que impedem tal publicização. Apesar da impossibilidade da confirmação empírica, esse capítulo se faz relevante, pois direciona o olhar para mecanismos possíveis e/ou prováveis, descartando hipóteses de ação logicamente irrelevantes, como empresas que vivem na ilegalidade fiscal optarem pela doação de campanha declarada. Essa redução do universo de possibilidades poderá permitir no futuro que se elabore metodologias de investigação das práticas ilegais aqui apresentadas. 


\section{Capítulo 5}

\section{Considerações finais}

Esta dissertação se propôs a estudar a corrupção política e o Caixa 2 de campanhas eleitorais no Brasil, analisando seu efeito sobre a qualidade da democracia, principalmente na dimensão da responsividade dos governos às preferências da maioria dos cidadãos. Foi analisada a (in)eficácia do accountability vertical como instrumento de punição dos corruptos, considerando o comportamento do eleitorado brasileiro diante desses fenômenos e dos investimentos feitos em marketing político, e como isso opera uma distorção na competição eleitoral. Investigou-se o conjunto de incentivos a que estão submetidos atores políticos e doadores de campanha no sentido da prática da corrupção e do uso do Caixa 2 no financiamento de campanhas eleitorais.

O problema em questão é de espectro amplo, uma vez que se pretendeu estudar efeitos macro de fenômenos complexos cuja explicação precisa ser pesquisada na ação individual dos envolvidos. Isso exigiu na investigação da literatura e na construção das hipóteses sugeridas uma navegação tanto horizontal entre temas distintos pertencentes a diferentes áreas da Ciência Política - comportamento eleitoral, corrupção política, accountability vertical, qualidade da democracia, entre outros - quanto vertical entre diferentes níveis - do macro dos efeitos agregados ao micro das decisões individuais.

Uma vez que se mostrou impraticável a obtenção de dados empíricos concretos sobre corrupção política e Caixa 2, as evidências empíricas analisadas foram baseadas em observações descritivas obtidas de notícias de jornal, artigos e depoimentos, já tendo tal opção heterodoxa sido explicada e suas limitações reconhecidas anteriormente nesta dissertação.

As evidências empíricas apresentadas no capítulo 4 apontam para a proliferação do uso de Caixa 2 no custeio das campanhas eleitorais em vários níveis e entre a maioria dos candidatos e dos principais partidos. A baixa - ou quase nula - incidência de denúncias e 
acusações entre oposição e situação quanto ao uso de Caixa 2 em campanhas, mesmo diante de evidências originadas por investigações policiais divulgadas pela mídia, sugere que o efeito "telhado de vidro" opera sobre a maior parte dos atores políticos.

As evidências empíricas existentes não são conclusivas quanto à preponderância do Caixa 2 nas receitas declaradas de campanhas eleitorais. Resta acreditar que essa proporção seja muito variável de um candidato a outro, como o é o montante total de receitas declaradas. Em alguns casos, as observações descritivas sugerem que o Caixa 2 supera em várias vezes o valor declarado das receitas. Alguns autores falam na proporção de cinco para um, em que apenas $20 \%$ das receitas oriundas de doações privadas seriam declaradas.

Também se faz relevante observar que mesmo os valores declarados como receitas de doação de campanha podem ter origem em doações feitas em Caixa 2 e "esquentadas" por "laranjas", conforme sugere investigação do TSE sobre as eleições de $2006^{55}$.

$\mathrm{O}$ fato de que as receitas declaradas ao TSE vem crescendo exponencialmente nos últimos pleitos, além de indicar o encarecimento das eleições, pode ser resultado da redução da proporção de Caixa 2 no total das doações de campanha, com a migração de Caixa 2 para receitas declaradas, ainda que tal declaração possa ser fraudulenta, com o uso de "laranjas". Sendo assim, embora tudo indique que as eleições têm ficado efetivamente mais caras na última década, esse encarecimento pode não estar se dando no mesmo ritmo observado nas receitas declaradas, se estiver ocorrendo uma redução no componente Caixa 2 das doações de campanha. Tal raciocínio consiste em um exercício especulativo, uma vez que carece de comprovação empírica.

Foram constatados exemplos de deficiências da Justiça Eleitoral em monitorar, fiscalizar e punir os abusos e desvios praticados no financiamento de campanhas, confirmando tanto o diagnóstico de cientistas políticos quanto declarações de magistrados do judiciário que reconhecem a ineficácia da instituição em coibir o Caixa 2 de campanha. Entre as causas dessas deficiências foram apontadas falhas na lei, como a possibilidade de doações ocultas através das doações aos partidos - e desses aos

\footnotetext{
${ }^{55} \mathrm{O}$ processo decorrente dessa investigação no Ministério Público foi posteriormente interrompido por duas decisões do próprio TSE referentes à necessidade de aprovação da justiça para quebra de sigilo bancário e ao prazo máximo de 180 dias após diplomação dos eleitos para apresentação de denúncia, conforme discutido em detalhes no capítulo 4, item 4.5.
} 
candidatos - burlando assim os limites legais e facilitando o "esquentamento" de doações Caixa 2 por empresas e cidadãos que atuam como "laranjas" mesmo sem ter faturamento e renda requeridos por lei para fazer tais doações. Outra "brecha" institucional constatada é a separação da Justiça Eleitoral das demais instâncias do judiciário brasileiro, reduzindo a cobertura e abrangência das investigações e processos de crimes correlatos ao Caixa 2 de campanha, como a corrupção política.

Também foram observadas questões processuais que contribuem para a impunidade como a impossibilidade de o Ministério Público investigar diretamente o descumprimento da lei eleitoral no que tange ao limite de doações por pessoas físicas e empresas, decorrente do recente entendimento do TSE de que o MP precisa pedir e solicitar à justiça, com base em evidências de crime cometido, autorização para a quebra de sigilo fiscal para ter acesso aos dados de renda e faturamento da Receita Federal.

Também foi apresentado como um entrave que reduz a possibilidade de constatação e punição do Caixa 2 nas campanhas eleitorais pela Justiça Eleitoral o limite de até 180 dias após a diplomação para denúncia de crime eleitoral por doação acima do limite, decidido pelo TSE em $2010^{56}$.

As perspectivas de reforma política são incertas, dada a complexidade dos arranjos institucionais e pelo risco de efeitos indesejáveis não previsíveis decorrentes das alterações das regras que regem a política. O debate, que ganhou vulto após os escândalos do "mensalão" no governo Lula, não chegou a adquirir a relevância política que o tema exige, e a sociedade civil parece tê-lo delegado a especialistas. Além disso, pouco se pode esperar de um corpo político eleito sob as regras vigentes no sentido de alterá-las para que sejam menos clientelistas.

A literatura da Ciência Política estudada apontou para um quadro grave de corrupção política em nosso país, conforme discutido no capítulo 2. A corrupção parece fazer parte da vida política e é percebida como generalizada pela sociedade. Os eleitores dão sinais de aceitar o fato de que os políticos são corruptos e tendem a não puni-los mesmo pelos casos de corrupção que vêm a público, seja pela sensação de que não há

\footnotetext{
${ }^{56}$ Para fins da reforma política como defendida por alguns autores, essas questões procedurais são de mais fácil solução do que aspectos legais, uma vez que não dependem de alteração na legislação, podendo ser endereçadas por acórdãos do TSE. Dependem, entretanto, da vontade política daquela corte, que recentemente produziu algumas decisões que podem ser interpretadas como entraves à fiscalização e punição do Caixa 2 nas eleições, conforme discutido no item 4.5 do capítulo 4 .
} 
alternativas viáveis, seja por indiferença. Os eleitores não parecem associar a prática de corrupção política aos déficits de qualidade da democracia brasileira, à desconsideração de suas próprias preferências em favor de uma elite corruptora na definição das prioridades de governo, e nem à piora nos serviços públicos e redução dos investimentos feitos pelos governos devido aos altos custos das contratações conduzidas sob esquemas de corrupção.

Diante dessa relativa aceitação por parte do eleitorado e da impunidade decorrente das ineficiências dos órgãos de controle responsáveis pelo accountability horizontal, os atores políticos se sentem à vontade para praticar a corrupção política, ao mesmo tempo em que são incentivados a fazê-lo diante da necessidade de levantar somas consideráveis e crescentes de recursos financeiros para fazer frente aos altos custos do marketing político, expressão maior do peso do dinheiro nas eleições, em uma arena eleitoral bastante competitiva e altamente fragmentada, onde os candidatos têm de competir não apenas entre partidos distintos, mas dentro dos próprios partidos e coligações no caso das eleições proporcionais para deputado federal e estadual e para vereador.

Embora a competição entre elites políticas em nosso país seja saudável, há indícios de que as elites financeiras que financiam esses políticos se mantêm hegemônicas, mesmo diante da alternância de poder político. À medida que possam exercer um controle considerável sobre as elites políticas, em função da relação de dependência do dinheiro que doam para as suas campanhas, aumentam as dúvidas sobre a qualidade da democracia na sua dimensão da competição. Além disso, as doações de campanha através de Caixa 2 podem estar servindo de instrumento adicional de controle sobre os políticos financiados ${ }^{57}$.

A análise descritiva deste estudo forneceu indícios comprobatórios da relação entre o Caixa 2 de campanha e a corrupção política. Pode-se supor uma relação de relevância nos dois sentidos, quer dizer, tanto parte considerável dos recursos aplicados sob a forma de Caixa 2 no financiamento de campanhas eleitorais tem por origem a corrupção política, quanto parte importante da corrupção política se destina ao financiamento de campanhas.

\footnotetext{
${ }^{57}$ Conforme mecanismo sugerido no item 4.6 do capítulo 4.
} 
Como sugerido pela literatura especializada, há um impacto direto da corrupção política na responsividade - uma dimensão central da qualidade da democracia. Isso se dá pela desconsideração das preferências da maioria dos cidadãos em favor das preferências de uma minoria que paga por esse privilégio através de propinas. Outra dimensão da qualidade da democracia impactada que merece destaque é a participação. A literatura dá conta de que a corrupção gera na sociedade desconfiança em relação à classe política e às instituições democráticas. Essa desconfiança reduz o interesse pela política e pode levar a prática da cidadania a um estado de apatia. Também a competição se vê afetada pela corrupção, na medida em que parte das propinas recebidas por candidatos e partidos em decorrência da prática da corrupção política é aplicada nas campanhas eleitorais, sob a forma de marketing político. Esse fenômeno pode ter atingido um nível no Brasil que tornaria o uso de recursos ilegais a única forma de mesmo os políticos originalmente honestos alcançarem e se manterem em posições de poder.

Essa distorção da competição a favor dos políticos envolvidos com a corrupção e a relativa tolerância ao fenômeno pelo eleitorado foram identificadas como as principais causas da ineficácia do accountability vertical no combate à corrupção política. Tudo indica que os corruptos não são punidos pelos eleitores de forma consistente.

As suspeitas levantadas por este estudo em relação à distorção da competição eleitoral e à ineficácia do accountability vertical no combate à corrupção têm implicações para a teoria da qualidade da democracia, pois chamam a atenção para um elemento importante que deve ser analisado ao se julgar as eleições: a qualidade da competição. Há um certo consenso político, social e acadêmico em torno do considerável respaldo e credibilidade de que gozam as eleições no Brasil. Nosso processo eleitoral ocorre dentro de uma aparência legal, confia-se na contagem de votos, e respeita-se os resultados oficiais. Em estudo recente publicado pela revista The Economist ${ }^{58}$ contendo a classificação democrática de 167 países, o Brasil aparece listado na $47^{\mathrm{a}}$ posição, com nota 7,12 em uma escala que vai de zero (autoritário) a 10 (democracia plena). Tal índice é composto de cinco fatores, um deles sendo "processo eleitoral e pluralismo", no qual o Brasil recebeu nota 9,58, igual a da Suécia, quarta colocada e de mais três países entre os 10 melhores colocados na classificação geral, e ainda acima de países como os EUA $(9,17)$ e o Japão $(9,17)$. Esse relativo consenso quanto à qualidade das eleições no Brasil

\footnotetext{
58 "Democracy index 2010, Democracy in retreat” - A report from the Economist Intelligence Unit (http://graphics.eiu.com/PDF/Democracy_Index_2010_web.pdf, acessado em 04 de janeiro de 2010).
} 
e a metodologia empregada na construção de índices como o adotado pelo estudo da The Economist citado acima, não condizem com os achados deste estudo. Ao que tudo indica, faz-se necessária uma revisão dos critérios adotados pela sociedade e pela literatura aqui estudada quanto ao que são eleições livres, competitivas e plurais, de modo a que tal percepção e as tipificações associadas sirvam melhor ao propósito de avaliar a qualidade da democracia e forneçam elementos para a construção de caminhos para o aprofundamento democrático.

Embora não seja objetivo deste estudo discutir trajetórias futuras para o problema estudado, é possível arriscar uma previsão de estabilidade do quadro apresentado, a menos na hipótese de eventos contingentes. Sem que o accountability vertical opere adequadamente a depuração contínua da classe política, dada a inibição da participação da sociedade pela desconfiança na classe política e nas instituições democráticas, e com a distorção da competição ${ }^{59}$ derivada do investimento de propina em marketing político, as chances de melhora da qualidade da democracia podem estar comprometidas.

No estudo citado da revista The Economist ${ }^{60}$, o Brasil foi classificado uma democracia defeituosa. Esses defeitos já não parecem ser característicos de um processo de transição democrática, como se acreditava há uma década, mas sim componentes intrínsecos de um regime estável, que contém em si mecanismos de preservação que levam a supor sua continuidade no tempo. Não se pode tampouco descartar a possibilidade de degradação da qualidade da democracia, principalmente se considerarmos o efeito continuado do desprestígio da carreira e da criminalização da atividade política sobre a renovação da própria classe política atuante no país.

Pensando-se em eventos contingentes que possam precipitar uma mudança no quadro apresentado, no sentido da melhora na qualidade da democracia com a redução da corrupção, é possível fazer um exercício tendo por ponto de partida a redução do Caixa 2 de campanha, decorrente de uma fiscalização mais eficaz pelos órgãos competentes e pela sociedade em geral. Cerceado o uso de dinheiro oriundo de corrupção política nas campanhas, e uma vez que isso valesse para todos os candidatos, a competição seria menos distorcida, mais equilibrada e, se não menos intensa, ao menos não tão cara, o que

\footnotetext{
${ }^{59}$ Participação e Competição são considerados os motores da democracia por Diamond e Morlino (2005).

60 "Democracy index 2010, Democracy in retreat" - A report from the Economist Intelligence Unit (http://graphics.eiu.com/PDF/Democracy_Index_2010_web.pdf, acessado em 04 de janeiro de 2010).
} 
aliviaria a pressão por recursos financeiros nas eleições. Isso abriria espaço para políticos que viessem a adotar estratégias anticorrupção e contrárias ao Caixa 2 em suas campanhas, interrompendo o ciclo em curso do efeito "telhado de vidro". Tais lideranças poderiam estimular maior participação política por parte da sociedade, ao se apresentarem como alternativa viável hoje não percebida pelos eleitores. Desse modo, o accountability vertical poderia passar a cumprir seu papel de desestimular a prática da corrupção através da punição eficaz dos corruptos, em um ciclo virtuoso no sentido de uma democracia de maior qualidade em nosso país.

Em decorrência da insuficiência de dados empíricos disponíveis, dado o segredo natural que envolve os fenômenos ilegais estudados, foi adotada uma abordagem heterodoxa que se valeu de observações descritivas obtidas de notícias de jornal, artigos, depoimentos e alguns dados de pesquisa em lugar de dados empíricos concretos. Como já era sabido, isso impôs algumas limitações e dificuldades ao estudo, dentre elas a impossibilidade de testar de forma conclusiva as hipóteses apresentadas. Nesse contexto, o que se pretendeu desde o princípio foi explorar alternativas explicativas aos fenômenos estudados, sugerindo mecanismos possíveis e/ou prováveis e descartando hipóteses logicamente irrelevantes. Tal caminho precisaria ser trilhado de qualquer modo, no sentido de criar condições à realização de pesquisas empíricas ortodoxas. Levando-se em conta a importância do tema e suas dificuldades empíricas, acredito que, ao trilhá-lo, foi dada uma contribuição modesta, mas a um tema de tanta importância pública. 


\section{APÊNDICE}

Tabela 6

Votação de candidatos líderes de escândalos políticos ${ }^{61}$

\begin{tabular}{|c|c|c|c|c|c|}
\hline Escândalo & $\begin{array}{c}\text { Personagem e } \\
\text { cargo disputado } \\
\text { em } 2010\end{array}$ & O que aconteceu & Em que pé está62 & $\begin{array}{l}\text { Votação } \\
\text { recebida }\end{array}$ & $\begin{array}{c}\text { Resultado } \\
\text { Eleitoral }\end{array}$ \\
\hline Caso Collor & $\begin{array}{l}\text { Fernando Collor } \\
\text { governador de AL }\end{array}$ & $\begin{array}{l}\text { O Congresso cassou o mandato de } \\
\text { presidente sob a acusação de } \\
\text { corrupção. }\end{array}$ & $\begin{array}{l}\text { O Supremo absolveu Collor em } 1994 . \\
\text { Ainda é réu em duas ações penais - uma } \\
\text { por corrupção e peculato em relação a } \\
\text { contratos de publicidade na época em que } \\
\text { era presidente e outra por crime tributário. }\end{array}$ & $\begin{array}{l}389.337 \text { votos } \\
\text { (derrotado no } \\
\text { primeiro turno) }\end{array}$ & Não foi eleito. \\
\hline Caso Sudam & $\begin{array}{c}\text { Jader Barbalho } \\
\text { senador }\end{array}$ & $\begin{array}{c}\text { AS Justiça decretou sua prisão em } \\
2002 \text { por envolvimento em fraudes } \\
\text { (desvio de dinheiro público) na } \\
\text { Sudam. }\end{array}$ & $\begin{array}{l}\text { A ação penal corre desde } 2004 \text { no STF e } \\
\text { não há previsão de julgamento. Já são } 11 \\
\text { volumes e } 47 \text { apensos. No dia } 06 \text { de julho, } \\
\text { os autos foram remetidos à Procuradoria. }\end{array}$ & 1.799 .762 votos & $\begin{array}{c}\text { Candidatura indeferida } \\
\text { Seria eleito. }\end{array}$ \\
\hline Propinoduto & $\begin{array}{c}\text { Anthony } \\
\text { Garotinho } \\
\text { deputado federal }\end{array}$ & $\begin{array}{l}\text { Fiscais e auditores do governo do } \\
\text { Rio foram acusados de enviar ao } \\
\text { exterior US } \$ 8,9 \text { milhões oriundos de } \\
\text { propinas pagas por empresas. }\end{array}$ & $\begin{array}{l}\text { Os fiscais foram condenados por lavagem } \\
\text { de dinheiro, corrupção e organização } \\
\text { criminosa. Garotinho, no entanto, ficou } \\
\text { livre de processo. Ele aparece ainda num } \\
\text { caso de compra de votos, num inquérito } \\
\text { parado no STF. }\end{array}$ & $\begin{array}{l}694.862 \text { votos } \\
\text { (mais votado no } \\
\text { RJ) }\end{array}$ & Eleito \\
\hline
\end{tabular}

${ }^{61}$ Tabela baseada em tabela publicada em O Estado de São Paulo, 08 de agosto de 2010 (disponível em

http://www.estadao.com.br/estadaodehoje/20100808/not_imp592058,0.php, acessado em 11 de janeiro de 2011). As duas últimas colunas ("votação recebida" e "resultado eleitoral") foram adicionadas por nós, a partir de dados obtidos em http://www.tse.gov.br.

62 À época, conforme reportagem do Jornal O Estado de São Paulo de 08 de agosto de 2010. 


\begin{tabular}{|c|c|c|c|c|c|}
\hline Escândalo & $\begin{array}{l}\text { Personagem e } \\
\text { cargo disputado } \\
\text { em } 2010 \\
\end{array}$ & O que aconteceu & Em que pé está62 & $\begin{array}{l}\text { Votação } \\
\text { recebida }\end{array}$ & $\begin{array}{c}\text { Resultado } \\
\text { Eleitoral }\end{array}$ \\
\hline Caso Renan & $\begin{array}{l}\text { Renan Calheiros } \\
\text { senador }\end{array}$ & $\begin{array}{l}\text { Foi acusado de receber ajuda de um } \\
\text { lobista para pagar despesas pessoais. }\end{array}$ & $\begin{array}{c}\text { Três anos depois, o inquérito tem } 43 \\
\text { volumes e ainda tramita no STF. Em } \\
\text { abril, a Procuradoria devolveu os autos ao } \\
\text { Supremo. }\end{array}$ & 840.809 votos & Eleito \\
\hline $\begin{array}{l}\text { Caso da } \\
\text { Bezerra }\end{array}$ & $\begin{array}{l}\text { Joaquim Roriz } \\
\text { governador do DF }\end{array}$ & $\begin{array}{l}\text { Renunciou ao mandato de senador } \\
\text { sob suspeita de usar o Banco de } \\
\text { Brasília para simular uma transação } \\
\text { e sacar } \mathrm{R} \$ 270 \text { mil. }\end{array}$ & $\begin{array}{c}\text { A denúncia só saiu em abril deste ano, } \\
\text { quase três anos depois, e aguarda } \\
\text { tramitação na Justiça. O TRE-DF } \\
\text { impugnou sua candidatura ao governo, } \\
\text { mas Roriz ainda pode recorrer e disputar a } \\
\text { eleição. } \\
\end{array}$ & - & $\begin{array}{l}\text { Renunciou à } \\
\text { candidatura. }\end{array}$ \\
\hline $\begin{array}{l}\text { Maluf e desvios } \\
\text { de verba }\end{array}$ & $\begin{array}{c}\text { Paulo Maluf } \\
\text { deputado federal }\end{array}$ & $\begin{array}{l}\text { É acusado de provocar um rombo de } \\
\text { R } \$ 1,2 \text { bilhão aos cofres da Prefeitura } \\
\text { de São Paulo, além de evasão de } \\
\text { divisas e compras e contratos } \\
\text { superfaturados. }\end{array}$ & $\begin{array}{l}\text { A lentidão da Justiça só o favorece. Uma } \\
\text { das ações no Supremo, que trata do rombo } \\
\text { na Prefeitura, se arrasta desde } 2001 \text { e } \\
\text { ficou parada três anos só para } \\
\text { depoimentos. }\end{array}$ & 497.000 votos & Eleito \\
\hline $\begin{array}{l}\text { Corrupção no } \\
\text { Espírito Santo }\end{array}$ & $\begin{array}{l}\text { José Carlos Gratz } \\
\text { senador }\end{array}$ & $\begin{array}{c}\text { Ex-presidente da Assembleia do ES, } \\
\text { foi preso em } 2003 \text { sob a acusação de } \\
\text { envolvimento em um esquema de } \\
\text { cobrança de propina e compra de } \\
\text { votos. }\end{array}$ & $\begin{array}{l}\text { Em uma das dezenas de ações a que } \\
\text { responde, foi condenado por improbidade. } \\
\text { Em outra, recebeu a punição de } 15 \text { anos } \\
\text { de prisão, mas a pena foi reduzida a } 10 \\
\text { anos. Ele recorreu e responde em } \\
\text { liberdade. }\end{array}$ & 12.774 votos & $\begin{array}{l}\text { Candidatura indeferida } \\
\text { Não seria eleito. }\end{array}$ \\
\hline \multirow[t]{3}{*}{ Mensalão } & $\begin{array}{c}\text { José Genoíno } \\
\text { deputado federal }\end{array}$ & \multirow{3}{*}{$\begin{array}{c}\text { Os quatro são personagens do } \\
\text { escândalo de pagamento de mesadas } \\
\text { pelo governo Lula a parlamentares } \\
\text { aliados. }\end{array}$} & \multirow{3}{*}{$\begin{array}{l}\text { Os três últimos escaparam da cassação na } \\
\text { Câmara. São todos réus no STF, mas a } \\
\text { previsão é de que a tramitação seja longa, } \\
\text { sem perspectiva de punição a curto prazo. } \\
\text { Processos na esfera cível também estão } \\
\text { parados. }\end{array}$} & 92.362 votos & Não foi eleito \\
\hline & $\begin{array}{l}\text { João Paulo Cunha } \\
\text { deputado federal }\end{array}$ & & & $\begin{array}{c}255.497 \text { votos } \\
\text { (candidato petista a } \\
\text { deputado federal } \\
\text { mais votado em } \\
\text { SP) } \\
\end{array}$ & Eleito \\
\hline & $\begin{array}{l}\text { Valdemar Costa } \\
\text { Neto } \\
\text { deputado federal } \\
\end{array}$ & & & 174.826 votos & Eleito \\
\hline
\end{tabular}




\begin{tabular}{|c|c|c|c|c|c|}
\hline Escândalo & $\begin{array}{l}\text { Personagem e } \\
\text { cargo disputado } \\
\text { em } 2010\end{array}$ & O que aconteceu & Em que pé está62 & $\begin{array}{l}\text { Votação } \\
\text { recebida }\end{array}$ & $\begin{array}{c}\text { Resultado } \\
\text { Eleitoral }\end{array}$ \\
\hline & $\begin{array}{c}\text { Paulo Rocha } \\
\text { senador }\end{array}$ & & & 1.733 .376 votos & $\begin{array}{l}\text { Candidatura indeferida } \\
\text { Não seria eleito. }\end{array}$ \\
\hline $\begin{array}{c}\text { Mensalão } \\
\text { mineiro }\end{array}$ & $\begin{array}{c}\text { Eduardo Azeredo } \\
\text { deputado federal }\end{array}$ & $\begin{array}{l}\text { É acusado de montar um esquema de } \\
\text { desvio de recursos em } 1998 \text { para } \\
\text { financiar sua campanha à reeleição. }\end{array}$ & $\begin{array}{l}\text { O Supremo aceitou a denúncia em } \\
\text { dezembro, mas o processo está apenas no } \\
\text { começo, sem previsão de punição a curto } \\
\text { prazo. }\end{array}$ & 123.649 votos & Eleito \\
\hline \multirow[t]{3}{*}{$\begin{array}{c}\text { Mensalão do } \\
\text { DF }\end{array}$} & $\begin{array}{c}\text { Geraldo Naves } \\
\text { deputado distrital }\end{array}$ & $\begin{array}{c}\text { Em novembro de } 2009 \text {, foi } \\
\text { revelado um esquema no DF de } \\
\text { cobrança de propina de empresas } \\
\text { e pagamento de mesada a políticos } \\
\text { aliados. } \\
\end{array}$ & $\begin{array}{l}\text { Deputados escaparam de punição na } \\
\text { Câmara Distrital. A investigação ainda } \\
\text { segue no Ministério Público Federal. }\end{array}$ & 1.439 votos & Não foi eleito \\
\hline & $\begin{array}{l}\text { Benício Tavares } \\
\text { deputado distrital }\end{array}$ & & & 17.558 votos & $\begin{array}{l}\text { Alcançou votos } \\
\text { suficientes para ser } \\
\text { eleito, mas sua } \\
\text { candidatura foi } \\
\text { indeferida } \\
\end{array}$ \\
\hline & $\begin{array}{c}\text { Benedito } \\
\text { Domingos } \\
\text { deputado distrital } \\
\end{array}$ & & & 9.479 votos & Eleito \\
\hline Sanguessugas & $\begin{array}{l}\text { Nilton Capixaba } \\
\text { deputado federal }\end{array}$ & $\begin{array}{c}\text { Em 2006, envolveu-se com a máfia } \\
\text { que desviava dinheiro público por } \\
\text { meio de emendas parlamentares e } \\
\text { compra de ambulâncias } \\
\text { superfaturadas. }\end{array}$ & $\begin{array}{l}\text { O Ministério Público denunciou pelo } \\
\text { menos } 285 \text { pessoas, entre eles, ex- } \\
\text { deputados federais como Capixaba. Os } \\
\text { processos se arrastam na Justiça e estão } \\
\text { em fase de instrução. }\end{array}$ & 52.016 votos & Eleito \\
\hline $\begin{array}{c}\text { Anões do } \\
\text { orçamento }\end{array}$ & $\begin{array}{l}\text { Genebaldo Correia } \\
\text { deputado federal }\end{array}$ & $\begin{array}{l}\text { Renunciou em } 1993 \text { no rastro do } \\
\text { escândalo de desvio de dinheiro } \\
\text { público por meio de emendas da } \\
\text { Comissão de Orçamento. US } \$ 1,6 \\
\text { milhão foi encontrado em sua conta. }\end{array}$ & $\begin{array}{c}\text { Foi denunciado em } 1994 \text { ao STF, mas em } \\
1999 \text { o processo foi enviado á Justiça } \\
\text { Federal depois que ele deixou de ser } \\
\text { deputado. Responde por improbidade. } \\
\text { Não passou um dia sequer preso. }\end{array}$ & 20.914 votos & Não foi eleito. \\
\hline
\end{tabular}




\begin{tabular}{|c|c|c|c|c|c|}
\hline Escândalo & $\begin{array}{c}\text { Personagem e } \\
\text { cargo disputado } \\
\text { em } 2010\end{array}$ & O que aconteceu & Em que pé está62 & $\begin{array}{l}\text { Votação } \\
\text { recebida }\end{array}$ & $\begin{array}{c}\text { Resultado } \\
\text { Eleitoral }\end{array}$ \\
\hline $\begin{array}{c}\text { Operação } \\
\text { Santa Tereza }\end{array}$ & $\begin{array}{l}\text { Paulo Pereira da } \\
\text { Silva } \\
\text { deputado federal }\end{array}$ & $\begin{array}{l}\text { Seu nome apareceu na operação da } \\
\text { PF que investigou o desvio de } \\
\text { dinheiro público e o uso fraudulento } \\
\text { de recursos do BNDES. }\end{array}$ & $\begin{array}{l}\text { O inquérito foi enviado ao STF em maio } \\
\text { de } 2008 \text { e ainda tramita na corte. No dia } \\
25 \text { de junho, os autos, de } 35 \text { volumes, } \\
\text { foram remetidos para a Procuradoria. }\end{array}$ & 267.208 votos & Eleito \\
\hline \multirow[t]{4}{*}{$\begin{array}{l}\text { Fraude } \\
\text { eleitoral }\end{array}$} & $\begin{array}{c}\text { Jackson Lago } \\
\text { governador do MA }\end{array}$ & $\begin{array}{c}\text { Os quatro foram acusados de abuso } \\
\text { de poder econômico durante a } \\
\text { campanha. }\end{array}$ & $\begin{array}{c}\text { Foram cassados pela Justiça Eleitoral por } \\
\text { abuso de poder econômico, mas não } \\
\text { ficaram proibidos de disputar eleição. }\end{array}$ & 569.412 votos & $\begin{array}{l}\text { Não foi eleito }\left(3^{\circ}\right. \\
\text { colocado) }\end{array}$ \\
\hline & $\begin{array}{l}\text { Cássio Cunha } \\
\text { Lima } \\
\text { senador }\end{array}$ & & & 1.004 .183 votos & $\begin{array}{c}\text { Alcançou o maior } \\
\text { número de votos para } \\
\text { senador no estado, mas } \\
\text { sua candidatura foi } \\
\text { indeferida. }\end{array}$ \\
\hline & $\begin{array}{c}\text { Mão Santa } \\
\text { senador }\end{array}$ & & & 433.690 votos & Não foi eleito. \\
\hline & $\begin{array}{c}\text { Marcelo Miranda } \\
\text { senador } \\
\end{array}$ & & & 340.931 votos & Eleito \\
\hline Caso Banespa & $\begin{array}{c}\text { Orestes Quércia } \\
\text { senador }\end{array}$ & $\begin{array}{l}\text { Investigações apontaram Quércia } \\
\text { como um dos responsáveis por um } \\
\text { rombo de R } \$ 2,8 \text { bilhões no antigo } \\
\text { banco público do Estado. }\end{array}$ & $\begin{array}{c}\text { Uma ação foi proposta pelo Ministério } \\
\text { Público de SP em 1996. Quércia ganhou } \\
\text { no Tribunal de Justiça. Procuradores } \\
\text { recorreram ao STJ, onde o caso está } \\
\text { parado. } \\
\end{array}$ & - & $\begin{array}{l}\text { Renunciou à } \\
\text { candidatura }\end{array}$ \\
\hline Caso Lunus & $\begin{array}{c}\text { Roseana Sarney } \\
\text { governadora do MA }\end{array}$ & $\begin{array}{c}\text { Em 2002, pré-candidata à } \\
\text { presidência, Roseana teve R } \$ 1,3 \\
\text { milhão, sem origem, apreendido em } \\
\text { escritório dela e do marido. }\end{array}$ & $\begin{array}{l}\text { O STF arquivou o caso em } 2003 \text { por } \\
\text { considerar que não havia elementos } \\
\text { contra Roseana. }\end{array}$ & 1.459 .792 votos & Eleita \\
\hline Atos secretos & $\begin{array}{c}\text { Agaciel Maia } \\
\text { deputado distrital }\end{array}$ & $\begin{array}{c}\text { O ex-diretor-geral do Senado é } \\
\text { apontado como mentor do esquema } \\
\text { de edição de boletins sigilosos para } \\
\text { nomear parentes e aliados de } \\
\text { senadores. }\end{array}$ & $\begin{array}{l}\text { Recebeu apenas uma suspensão do } \\
\text { Senado e o inquérito ainda tramita no } \\
\text { Ministério Público Federal. }\end{array}$ & 14.065 votos & Eleito \\
\hline
\end{tabular}




\section{Referências Bibliográficas}

ALMEIDA, Alberto Carlos. Amnésia eleitoral: em quem você votou para deputado em 2002? E em 1998? In: SOARES, Glaucio Ary Dillon e RENNÓ, Lucio R. (orgs.). "Reforma política. Lições da história recente". Editora FGV, 2006-a, 34-46.

Por que Lula? Rio de Janeiro: Record, 2006-b.

A cabeça do brasileiro. Rio de Janeiro: Record, 2007.

A cabeça do eleitor. Rio de Janeiro: Record, 2008.

ALMEIDA, Roberto. Cerco a doações ilegais põe quase 4 mil contribuintes sob suspeita. O Estado de São Paulo, 06 de junho de 2009. Disponível em http://www.estadao.com.br/estadaodehoje/20090607/not_imp383590,0.php. Acesso em 09 de janeiro de 2011.

AMARAL, Gilberto L do; AMARAL, Letícia M.F. do; OLENIKE, João E. e STEINBRUCH, Fernando. Estudo sobre sonegação fiscal das empresas brasileiras. Curitiba: $\quad$ IBPT, $2009 . \quad$ Disponível em http://www.ibpt.com.br/img/_publicacao/13649/175.pdf. Acesso em 12 de dezembro de 2010.

ARANTES, Rogério B. The Brazilian feds: the Federal Police and the Ministério Público in fight against corruption. In: POWER, Timothy e TAYLOR, Matthew (orgs.). Corruption and democracy in Brazil: The struggle for accountability. Notre Dame University Press, no prelo.

BIGNOTTO, Newton. Corrupção e Estado de direito. In: ANASTASIA, Fátima e AVRITZER, Leonardo (orgs.). Reforma política no Brasil. Belo Horizonte: Editora UFMG, 2006, p. 82-86.

BOBBIO, Norberto; MATTEUCCI, Nicola \& PASQUINO, Gianfranco. Dicionário de política. Brasília, Editora UNB, Brasília, 2007.

CAMPOS, Mauro M. Democracia, partidos e eleições: Os custos do sistema partidárioeleitoral no Brasil. 2009. Tese de doutorado. DCP/FAFICH/UFMG. Belo Horizonte. 2009. 
CANACHE, Damarys e ALLISON, Michael E. Perceptions of political corruption in Latin American democracies. Latin American Politics and Society, Miami, v. 47, n. 3, p. 91$111,2005$.

CARDOSO, Fernando Henrique. O presidente segundo o sociólogo. São Paulo: Companhia das Letras, 1998.

CARREIRÃO, Yan de Souza. Identificação ideológica, partidos e voto na eleição presidencial de 2006. Opinião Pública, Campinas, v. 13, p. 307-339, novembro de 2007.

CERVELLINI, Silvia. Marketing político e marketing comercial: uma reflexão". In: FIGUEIREDO, Rubens (org.). Marketing político e persuasão eleitoral. São Paulo: Konrad Adeanuer, 2000, p. 83-112.

CLEMENTE, Isabel; LOYOLA, Leandro; RAMOS, Murilo e MENDONÇA, Ricardo. Pesquisa Congresso no espelho - Como o Congresso se enxerga. Revista Época, 06 de Julho de 2009.

DAHL, Robert. Poliarquia: participação e oposição. São Paulo: Edusp, 1977.

DIAMOND, Larry. Elections without democracy: thinking about hybrid democracies. Journal of Democracy, v. 13, n. 2, p. 21-35, 2002.

DIAMOND, Larry e MORLINO, Leonardo. Assessing the quality of democracy. Baltimore: The John Hopkins University Press, 2005.

ECONOMIST INTELLIGENCE UNIT. Democracy index 2010. Democracy in retreat. A report for the Economist Intelligence Unit. Disponível em www.eiu.com. Acesso em 11 de janeiro de 2010.

FILGUEIRAS, Fernando. Marcos teóricos da corrupção. In: AVRITZER, Leonardo; BIGNOTTO, Newton; GUIMARÃES, Juarez e STARLING, Heloisa M. M. (orgs.). Corrupção: ensaios e críticas. Belo Horizonte: Editora UFMG, 2008-a, p. 353-362.

Corrupção, democracia e legitimidade. Belo Horizonte: Editora UFMG, 2008-b.

HUNTER, Wendy. Corrupção no Partido dos Trabalhadores. O dilema do "sistema." In: NICOLAU, Jairo e POWER, Timothy J. (orgs.). Instituições representativas no Brasil. Balanço e reforma". Belo Horizonte: Editora UFMG, 2007, 155-169.

HUNTINGTON, Samuel P. Political order in changing societies. New Haven, Yale University Press, 1968.

INGLEHART, Ronald e WELZEL, Christian. Modernization, cultural change, and 
democracy. The human development sequence. Cambridge: Cambridge University Press, 2005.

JARDIM, Torquato. A regulamentação legal dos partidos políticos no Brasil. Revista Paraná Eleitoral, n. 52, não paginado, abril de 2004. Disponível em http://www.paranaeleitoral.gov.br/artigo_impresso.php?cod_texto=189. Acesso em 08 de dezembro de 2010.

LAVAREDA, Antonio. Emoções ocultas e estratégias eleitorais. Rio de Janeiro: Objetiva, 2009.

MARENCO, André. Financiamento de campanhas eleitorais. In: AVRITZER, Leonardo; BIGNOTTO, Newton; GUIMARÃES, Juarez e STARLING, Heloisa M.M. (orgs). Corrupção: ensaios e críticas. Belo Horizonte: Editora UFMG, 2008, p. 381-387.

MAURO, Paolo. The persistence of corruption and slow economic growth. IMF Working Paper, Research Department, 2002. Disponível em: http://www.imf.org/external/pubs/ft/wp/2002/wp02213.pdf. Acesso em 09 de janeiro de 2011.

MELO, Carlos Ranulfo. Corrupção eleitoral. In: AVRITZER, Leonardo, BIGNOTTO, Newton, GUIMARÃES, Juarez e STARLING, Heloisa M.M. (orgs). Corrupção: ensaios e críticas. Belo Horizonte: Editora UFMG, 2008, p. 373-380.

MIGUEL, Luís Felipe. Impasses da accountability: dilemas e alternativas da representação política. Revista de Sociologia e Política, Curitiba, n. 25, p. 25-38, novembro de 2005.

MISHLER, William e ROSE, Richard. What are the origins of political trust? Testing institutional and cultural theories in post-communist societies. Comparative Political Studies, v. 34, n. 1, p. 30-62, fevereiro de 2001.

What are the political consequences of trust? A test of cultural and institutional theories in Russia. Comparative Political Studies, v. 38, n. 9, p. 1050-1078, novembro de 2005.

MOISÉS, José Álvaro. Cultura política, instituições e democracia. Revista Brasileira de Ciências Sociais, São Paulo, v. 23, n. 66, p. 11-43, fevereiro de 2008.

Democracia, desconfiança política e insatisfação com o regime - O caso do Brasil. Opinião Pública, Campinas, v. 14, n.1, p. 1-42, junho de 2008-b.

Corrupção política e democracia no Brasil contemporâneo. Texto não publicado, 2008-c. 
A corrupção afeta a qualidade da democracia? Em Debate, Belo Horizonte, v. 2, n. 5, p.37-37, maio de 2010 .

MOISÉS, José A (org.). Democracia e Confiança. Por que os Cidadãos Desconfiam das Instituições Públicas. São Paulo: Edusp, 2010.

MORLINO, Leonardo. Legitimacy and the quality of democracy. International Social Science Journal, Oxford, v. 60, n. 196, p. 211-222, junho de 2009.

NICOLAU, Jairo. O sistema eleitoral de lista aberta no Brasil. In: NICOLAU, Jairo e POWER, Timothy J. (orgs). Instituições representativas no Brasil. Balanço e reforma. Belo Horizonte: Editora UFMG, 2007, p. 97-123.

Como controlar o representante? Considerações sobre as eleições para a Câmara dos Deputados no Brasil. Dados, Rio de Janeiro, v. 45, n. 2, p. 219-236, 2002.

NORRIS, Pippa. Critical Citizens. Oxford: Oxford University Press, 1999.

O'DONNELL, Guillermo. Why the Rule of Law Matters. In: DIAMOND, Larry e MORLINO, Leonardo (orgs.). Assessing the quality of democracy. Baltimore: The John Hopkins University Press, 2005, 3-17.

NYE, Joseph. Corruption and Political Development: a cost-benefit analysis. American Political Science Review, Los Angeles, v.61, n.4, p. 417-427, 1967.

PALMER, Jerry. Smoke and mirrors: is that the way it is? Themes in political marketing. Media, Culture \& Society, v. 24, n. 3, p. 345-363, 2002.

PIMENTEL JR, Jairo T.D. Razão e emoção no voto: o caso da eleição presidencial de 2006. 2007. Dissertação de mestrado. DCP/FFLCH/USP. São Paulo. 2007.

POSADA-CARBÓ, Eduardo. Democracy, parties and political finance in Latin America. Working paper 346, commissioned by the National Endowment for Democracy, presented at the conference held by the Sejung Institute on Party Finances in East Asia. Kellogg Institute, Notre Dame University, 2008. Disponível em http://www.nd.edu/ kellogg/publications/workingpapers/WPS/346.pdf. Acesso em 09 de janeiro de 2011.

POWELL JR, C. Bingham. The Chain of Responsiveness. In: DIAMOND, Larry \& MORLINO, Leonardo. Assessing the Quality of Democracy. Baltimore: The John Hopkins University Press, 2005, 62-67.

POWER, Thimothy J. e GONZÁLES, Júlio. Cultura política, capital social e percepções sobre corrupção: uma investigação quantitativa em nível mundial. Revista de Sociologia e Política, Curitiba, n. 21, novembro de 2003, p. 51-69. 
RENNÓ, Lucio. O dilema do rico: número de candidatos, identificação partidária e accountability nas eleições de 2002 para a Câmara dos Deputados. In: SOARES, Glaucio Ary Dillon e RENNÓ, Lucio R. (orgs). Reforma política. Lições da história recente. Rio de Janeiro: Editora FGV, 2006, p. 47-70.

RIBEIRO, Renato J. Financiamento de campanha (público versus privado). In: ANASTASIA, Fátima e AVRITZER, Leonardo (orgs). Reforma política no Brasil. Belo Horizonte, Editora UFMG, 2006, p. 77-81.

ROSE-ACKERMAN, Susan. Corruption and government: causes, consequences, and reform. Cambridge: Cambridge University Press, 1999.

RUESCHEMEYER, Dietrich. Addressing inequality. In: DIAMOND, Larry e MORLINO, Leonardo. Assessing the quality of democracy. Baltimore: The John Hopkins University Press, 2005, 47-61.

SAMUELS, David. Financiamento de campanhas no Brasil e propostas de reforma. In: SOARES, Glaucio Ary Dillon e RENNÓ, Lucio R. (orgs). Reforma política. Lições da história recente. Rio de Janeiro: Editora FGV, 2006, 133-153.

SCHMITTER, Philippe C. The Ambiguous Virtues of Accountability. In: DIAMOND, Larry e MORLINO, Leonardo. Assessing the quality of democracy. Baltimore: The John Hopkins University Press, 2005.

SINGER, André. Esquerda e direita no eleitorado brasileiro. São Paulo: Edusp, 2000.

SPECK, Bruno. O financiamento político no Brasil: normas e práticas vigentes. OEA/IDEA, 2003. Relatório de pesquisa para projeto comparativo da OEA/IDEA. (mimeo)

O financiamento de campanhas eleitorais. In: ANASTASIA, Fátima e AVRITZER, Leonardo (orgs). Reforma política no Brasil. Belo Horizonte: Editora UFMG, 2006, p. 153-158.

STARLING, Heloisa M.M. Machado de Assis. In: AVRITZER, Leonardo; BIGNOTTO, Newton; GUIMARÃES, Juarez e STARLING, Heloisa M.M. (orgs). Corrupção: ensaios e críticas. Belo Horizonte: Editora UFMG, 2008, p. 263-272.

TAYLOR, Matthew. Justiça eleitoral. In: ANASTASIA, Fátima e AVRITZER, Leonardo (organizadores). Reforma política no Brasil. Belo Horizonte: Editora UFMG, 2006, p. 147-152.

TREISMAN, Daniel. The causes of corruption: a cross-national study. Journal of Public Economics, Los Angeles, CA, v. 76, n. 3, p. 399-457, Junho 2000. 